\title{
Proposições para a melhoria da qualidade do sangue Hemocentro de Botucatu
}

\section{Gilberto Luppi dos Anjos}

Tese de Doutorado apresentada ao

Programa de Pós-Graduação em Saúde Pública para obtenção do título de Doutor em. Saúde Pública

Área de concentração:

Serviços de Saúde Pública

Orientador: Prof. Dr. Cláudio Gastão Junqueira de Castro

\section{São Paulo}




$$
45460 / 2005 \text { dre }
$$

Autorizo, exclusivamente para fins acadêmicos e científicos, a reprodução total ou parcial desta tese, por processos fotocopiadores.

Assinatura:

Data: 
A posição expressa a unidade: não são dois, e não é um... Corpo e mente não são dois nem um. Se você pensa que corpo e mente são dois, está errado; se pensa que são um, também está errado; nosso corpo e mente são ambos dois e um. Normalmente, pensamos que, se alguma coisa não é una, deve ser mais de uma; se não é singular, é plural. Porém, na experiência real, nossa vida não é apenas plural, mas também singular. Cada um de nós é dependente e independente.

\section{Roshi Suzuki}




\section{AGRADECIMENTOS}

Ao Prof. Dr. CLÁUDIO GASTÃo JUNQUEIRA DE CASTRO, meu orientador, que propiciou a tranqüilidade necessária para realizar, com prazer, a tarefa de escrever as palavras que compõe a totalidade deste trabalho.

Ao Professor Titular do Departamento de Bioestatística do Instituto de Biociências UNESP, Dr. CARLOS ROBERTO PADOVANI, pelo auxilio no trabalho e apresentação dos dados.

Ao Professor Titular do Departamento de Física do Instituto de Biociências UNESP, Dr. IVAN AMARAL GUERRINI, pela acolhida e incentivo no caminho escolhido.

Aos amigos MAGALI ALVAREZ, TÂNIA PUPO, PAULINHO POMPIANI, INÊS DOTTI e RITA DE CASSIA ROCHA para quem as palavras não são necessárias.

A TODOS aqueles que, de alguma forma, relacionaram-se com a execução deste trabalho; pois, embora a escrita seja uma atividade solitária, só pode ser construída com o auxilio, a intuição, as idéias dos amigos com os quais compartilho os resultados ora apresentados. 


\section{RESUMO}

Anjos GL. Proposições para Melhoria da Qualidade do Sangue - Hemocentro de Botucatu. São Paulo; 2001. [Tese de Doutorado - Faculdade de Saúde Pública da USP].

Objetivo. Realizar avaliação ex-ante para renovar programação de captação de doadores de sangue do Hemocentro de Botucatu, estabelecendo-se perfis dos doadores e dos trabalhadores a eles diretamente relacionados, sob a ótica do Vínculo e sob as disciplinas: domínio pessoal, modelos mentais, visão compartilhada, aprendizagem em equipe e raciocínio sistêmico. Descrever procedimentos para otimização de custos e as diversas formas de captação de doadores existentes. Método. Realizaram-se entrevistas a doadores voluntários espontâneos habituais, a doadores com evento único de doação. Montou-se o Discurso do Sujeito Coletivo (DSC) dos dois grupos. As maneiras existentes de captação foram identificadas e descritas. Foram descritos procedimentos para otimização de custos. Realizadas entrevistas com trabalhadores envolvidos diretamente com doadores de sangue, as questões apresentadas relacionaram-se às teorias de Peter Senge, sobre organizações de aprendizagem; montou-se o DSC a partir das idéias centrais apresentadas nos discursos individuais. Entrevistas com profissionais psicólogos esclareceram objetivos, métodos de trabalho e resultados das abordagens terapêuticas. Os dados foram descritos e apresentados, em sua distribuição de frequiências, por meio de gráficos e tabelas. Resultados e Discussão. Os doadores apresentam perfis semelhantes entre os grupos e a literatura. Houve coincidência em oito idéias centrais de motivação para a doação. Destacou-se a motivação por pressão social como principal fator desencadeante da primeira doação $(76,3 \%$ e $61,5 \%)$ e a motivação relacionada à solidariedade e humanitarismo $(23,6 \%$ e $26,8 \%)$. No grupo de doadores freqüentes a motivação para voltar a doar apresentou-se como solidariedade e humanitarismo com $63,2 \%$ e pressão social de $18,4 \%$. A motivação para não voltar a doar no grupo de doadores de evento único de doação foi de falta de tempo, oportunidade ou estímulo $(30,8 \%)$, dificuldades de acesso $(23,1 \%)$ e problemas de saúde $(19,2 \%)$. O DSC dos trabalhadores apontou como projeto de vida pessoal o cuidado com a família como principal idéia central $(92,3 \%)$; nos projetos profissionais destacaram-se a continuidade dos estudos $(69,3 \%)$ e a estagnação profissional $(38,5 \%)$; sobre a existência de projetos comuns de trabalho, apresentouse a idéia central de individualismo $(61,5 \%)$; sobre os doadores, os trabalhadores mostraram conhecimento de suas características sociais e motivações, fato destacado por profissional psicólogo. Observou-se os Modelos Mentais de continuidade dos estudos como fator de crescimento profissional e aumentos de consumo de sangue em feriados; arquétipos de transferência de responsabilidade para o captador, pela falta de sangue e de equilíbrio com defasagem, nas oscilações de captação de doadores. No Pensamento Sistêmico destacou-se a falta de informações, deficiências de estrutura turvando a visão da realidade, o estímulo ao Vínculo como alavanca para normalização dos estoques e a criação de espaços formais de comunicação para desfazer fofocas e individualismo. Conclusões. O sistema de informações deve ser reorganizado; a equipe de trabalhadores deve corresponder às expectativas dos doadores como elo ao Vínculo; a Roda é opção para criação de espaço formal de 
comunicação onde as informações devem fluir construtivamente apontando soluções coletivas para melhoria dos inter-relacionamentos e construção do Vínculo com o doador de sangue. Indicadores de qualidade do sangue coletado e novas entrevistas podem constituir instrumentos para avaliação posterior.

Descritores: doações de sangue; doadores; vínculo, pensamento sistêmico; qualidade do sangue. 


\section{SUMMARY}

Anjos GL. Proposições para Melhoria da Qualidade do Sangue - Hemocentro de Botucatu. [Proposals to Improve Blood Quality - Botucatu Blood Center]. São Paulo (BR); 2004. [Tese de Doutorado - Faculdade de Saúde Pública da Universidade de São Paulo].

Objective. To carry out an ex-ante evaluation at Botucatu Blood Center in order to renew the planning for blood donator's picking up, thus establishing donators and workers profiles, directly related to them, from the view of Bond and under the following subjects: Personal Domain, Mental Models, Shared Views, Team-work learning and Systemic Reasoning. To describe procedures for controlling costs and the different ways for picking up existing donators. Method. Interviews with spontaneous and habitual volunteer donators, and with donators who have done it just once. The Collective Subject Speech (CSS) was build for each of the two groups. Existing ways for picking up donators were identified and described. Procedures for controlling costs were described. Interviews were done with workers directly involved with blood donators, the issues shown were related to Peter Senge's theories about learning organization. The Collective Subject Speech was build from the main ideas presented in the individual speeches. Interviews with professional psychologist clarified objectives, working methods and results of therapeutic approaches. The pieces of information were described and presented, in its frequency distribution, by the means of graphs and tables. Results and Discussion. The donators show similar profiles among the groups and literature. There were coincidences in eight of the main ideas about motivation for donation. Motivation due to social pressure stood out as the main setting off factors for the first donation $(76,3 \%$ and $61,5 \%)$ as well as the motivation related to solidarity and humanitarianism $(23,6$ and $26,8 \%)$. In the group of frequent donators the motivation to donate again appeared mainly as solidarity and humanitarianism at the rate of $63,2 \%$ and social pressure at the rate of $18,4 \%$. The motivation for not donating a second time in the group of donators who did it just once were lack of time, lack of opportunity and lack of incentive $(30,8 \%)$, difficulty of access $(23,1 \%)$ and health problems $(19,2 \%)$. The workers' Collective Subject Speech pointed family care as the main idea for personal life project $(92,3 \%)$; among the professional projects, studies continuity settled off at the rate of $69,3 \%$ and profession stagnation at the rate of $38,5 \%$; about existing shared work projects, individualism appeared as the main idea $(61,5 \%)$. About donators, the workers showed knowledge of their social traits as well as their donating motivations, which were emphasized by professional psychologist. Mental Models of studies continuity as a factor for professional growth were observed, and so were observed mention to blood consumption increase during holidays. Archetypes of responsibility transferring to the professionals in charge on blood's picking up for blood's running out and balance gaps when donator's number oscillate were also observed. In the Systemic Reasoning, lack of information, structural deficiencies (clouding the view of reality), stimulus to Bond as gear lever for bringing back to normal the stocks and the establishment of formal communicational opportunities in order to vanish individualism and gossiping were emphasized. Conclusions. The information system should be organized; the team of workers should reach donators' expectations as a link to the Bond. The "Circle" is an 
option as a formal communication opportunity, where the information is supposed to flow constructively, searching for collective solutions, in order to improve inter relationships as well as to build Bonds with blood donators. Indicators of quality for the blood collected and new interviews may constitute tools for later evaluation.

Descriptors: Blood donations; donators; bonds; systemic reasoning; blood quality. 


\section{ÍNDICE}

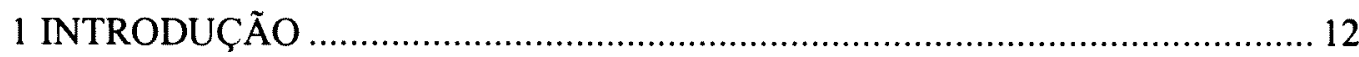

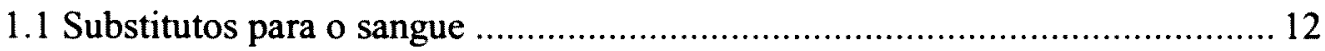

1.2 Aspectos históricos e do direito sobre a hemoterapia ................................ 13

$1.3 \mathrm{O}$ Hemocentro de Botucatu: história e objetivos ........................................ 21

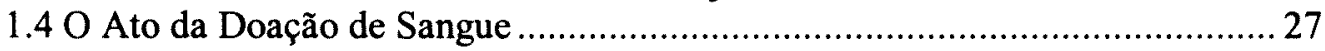

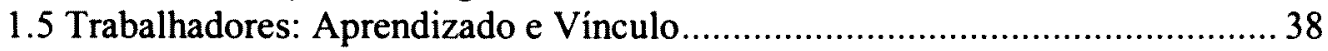

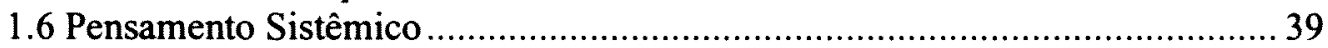

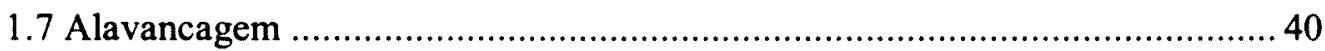

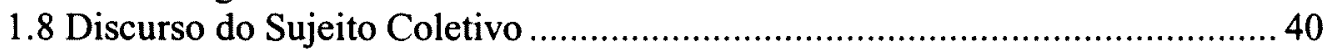

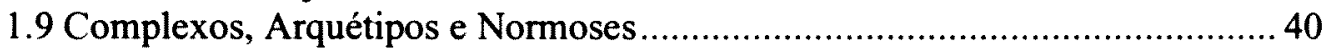

1.10 Avaliação de serviços e programas sociais................................................. 41

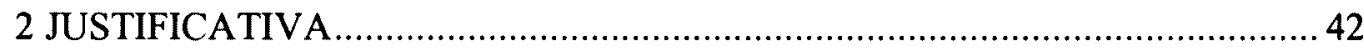

3 OBJETIVO

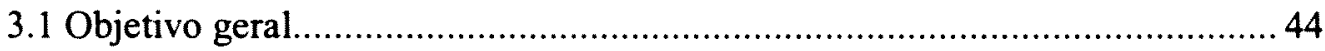

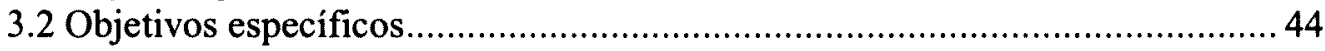

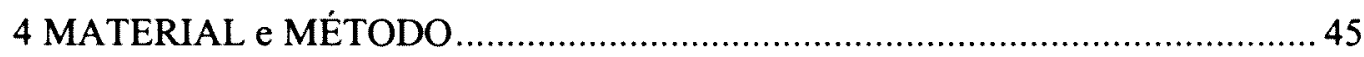

4.1 Estudo da população de doadores de sangue de menor risco ........................ 45

4.2 Estudo de população de doadores com evento único de doação de sangue ..... 46

4.3 Otimização de custos.............................................................................4 46

4.4 Identificação e padronização das formas de captação................................. 48

4.5 Trabalho e Vínculo com o doador de sangue ............................................49 49

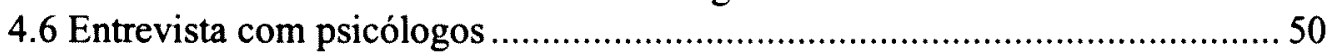

5 RESULTADOS E DISCUSSÃO ............................................................... 51

5.1 Considerações gerais sobre as coletas e qualidade dos dados ...................... 51

5.2 Perfil do doador de menor risco: doador regular ou capacitado ..................... 52

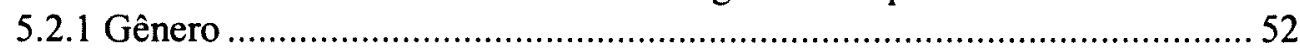

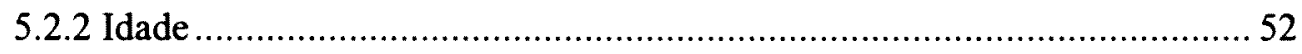

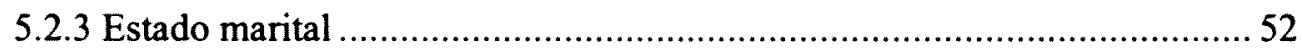

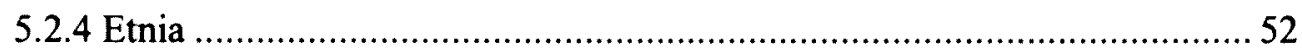

5.2.5 Ocupação e escolaridade ............................................................. 53

5.3 Perfil do doador de maior risco: doadores com único evento de doação ......... 61

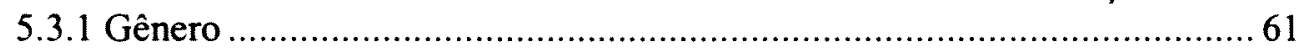

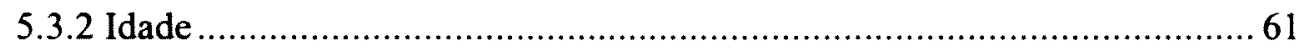

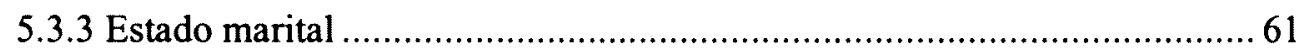

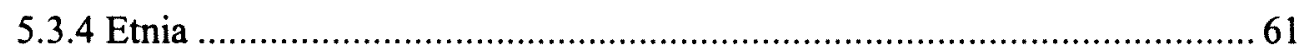

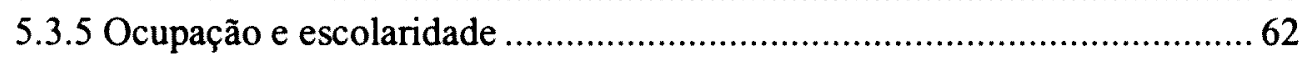

5.3.6 Motivação para doação - O Discurso do Sujeito Coletivo ......................62

5.3.7 Motivos para não tornar a doar - O Discurso do Sujeito Coletivo.............65

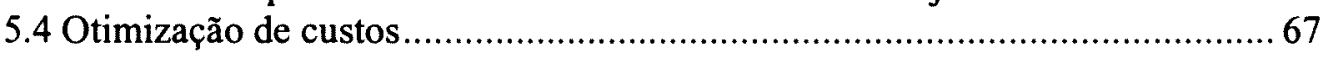

5.5 Histórico recente das atividades de captação de doadores de sangue .................69

5.5.1 Atividades de captação e capacitação .............................................. 70

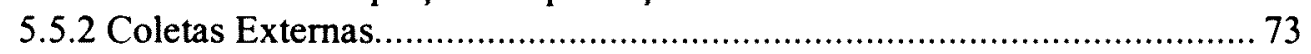


5.5.3 Doações por trabalhadores de empresas............................................... 74

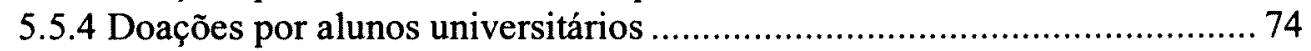

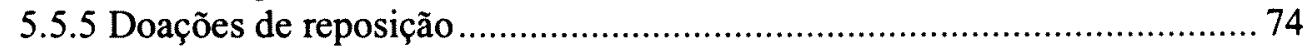

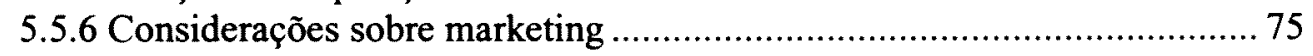

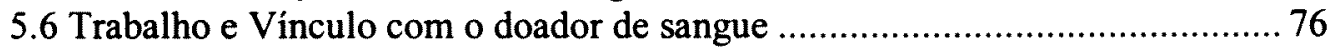

5.6.1 O Trabalhador - Discurso do Sujeito Coletivo ..................................... 76

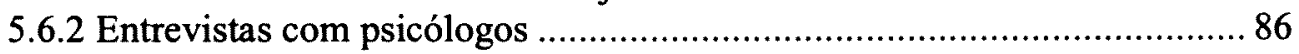

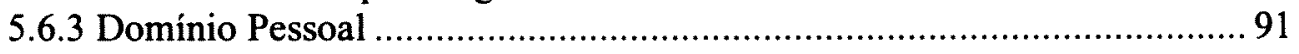

5.6.4 Objetivos Comuns ........................................................................ 93

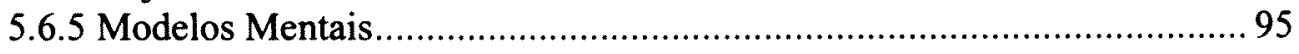

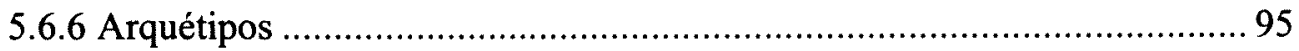

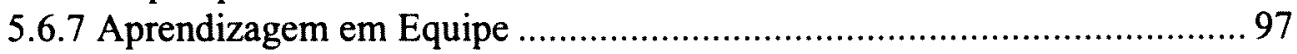

5.6.8 Utilizando o Pensamento Sistêmico .................................................. 97

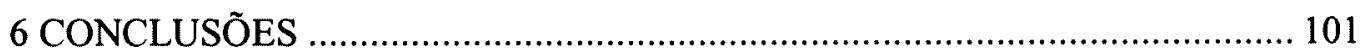

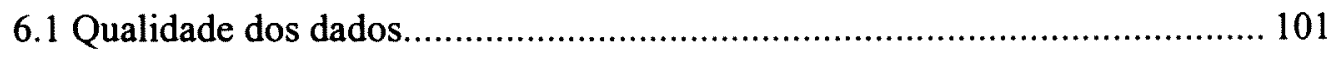

6.2 Captação e Capacitação de doadores de sangue ......................................... 101

6.3 Recepção e cadastro de doadores de sangue................................................ 102

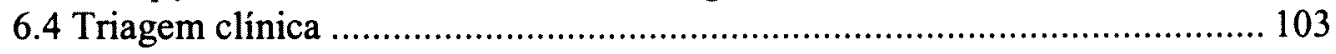

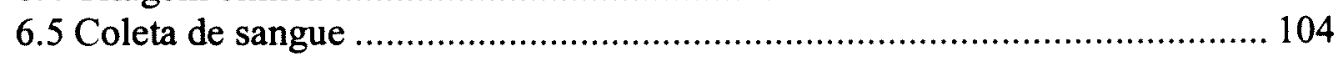

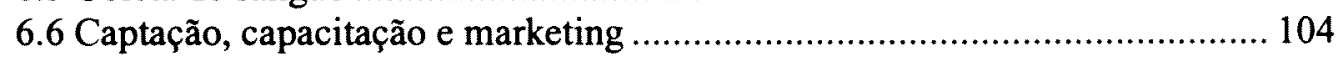

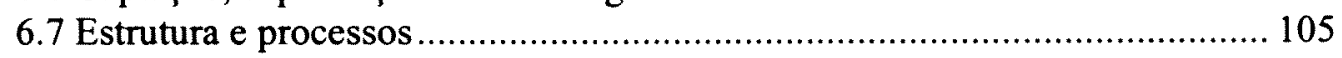

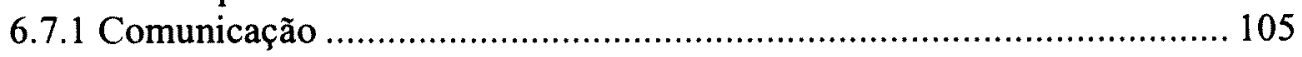

6.7.2 Expectativas dos doadores de sangue ............................................. 109

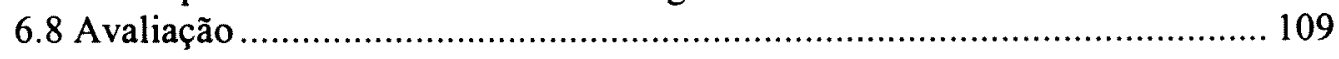

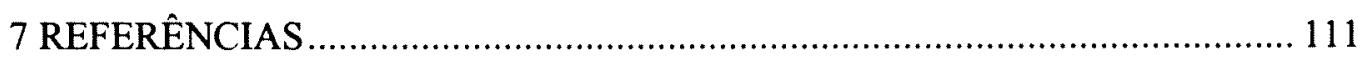

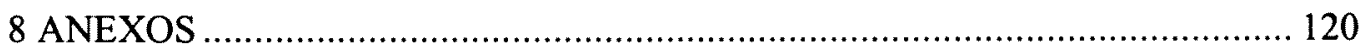




\section{ÍNDICE DE TABELAS, GRÁFICOS, ESQUEMAS e FIGURAS}

Tabela 1. Descartes de bolsas de sangue por validade $\quad 47$

Tabela 2. Bolsas de sangue utilizadas ou distribuídas $\quad 47$

Tabela 3. Percentual de bolsas de sangue perdidas/utilizadas ou distribuídas $\quad 47$

Tabela 4. Distribuição das idades segundo sexo - doador de repetição 52

Tabela 5. Distribuição das idades segundo sexo - doadores de único evento 61

Tabela 6. Distribuição das idéias centrais de motivação inicial para a doação 64

Tabela 7. Distribuições de rejeições clínicas e sorológicas segundo custos $\quad 68$

Tabela 8. Distribuição de descartes de bolsas por validade segundo custos $\quad 69$

Gráfico 1. Percentual de bolsas de sangue perdidas/utilizadas ou distribuidas $\quad 48$

Esquema 1. Arquétipos $\quad 96$

Esquema 2. Pensamento Sistêmico $\quad 98$

Esquema 3. Pensamento Sistêmico 98

$\begin{array}{ll}\text { Esquema 4. Pensamento Sistêmico } & 100\end{array}$

Figura 1. Hemorrede $\quad 18$

Figura 2. Organograma $\quad 26$

Figura 3. Bolsas de sangue utilizadas ou distribuídas 47 


\section{INTRODUÇÃo}

\subsection{Substitutos para o sangue}

Desde o final do século XIX procura-se encontrar substitutos para o sangue no tratamento de anemias, através de soluções parenterais. $O$ interesse nessas soluções intensificou-se por conseqüências da I ${ }^{\mathrm{a}}$ Guerra Mundial, por resultados de hemorragias agudas e choque hipovolêmico que poderiam ser revertidos com a administração de fluidos intravasculares para a expansão de volume e transporte de oxigênio, facilmente transportáveis e armazenáveis, com o intuito de salvar vidas de soldados feridos (DIETZ ${ }^{l}$ ).

Em 1996, em artigo revisional, DIETZ ${ }^{1}$ e colaboradores apontam a necessidade de pesquisas de "substitutos do sangue", definidos como expansores de volume e carreadores de oxigênio, pela estimativa de demanda transfusional de 12 a 13 milhões de unidades de concentrados de hemácias ao ano, em 2.030, para população idosa, de 65 anos ou mais, nos Estados Unidos. Estas quantidades seriam insuficientes para aquele ano e acumulariam déficit de 4 milhões de unidades.

Segundo DIETZ ${ }^{1}$, os principais expansores de volume carreadores de oxigênio em desenvolvimento são as soluções de hemoglobina, a hemoglobina lipossoma-encapsulada e os perfluorocarbonos, aplicados nas clínicas nas rotinas peri-operatórias, na perfusão de órgãos em isquemia, no trauma, na hemodiluição intra-operatória, no choque séptico e na terapia de tumores. Os autores citam dificuldades no estabelecimento da eficácia de vários dos produtos em recente desenvolvimento relacionadas a efeitos indesejáveis como vasoconstricção e hipertensão, que limitam em muito o uso em idosos com suas doenças preexistentes. Outros fatores incluem a meia-vida curta desses produtos que, naquele momento, apenas retardariam a transfusão de concentrados de hemácias. Os autores sugeriam a necessidade de pesquisas adicionais para a demonstração desta eficácia.

Em 1998, BRYSON ${ }^{2}$ e colaboradores revisaram a literatura sobre possibilidades de redução de transfusões peri-operatórias pelo uso de técnicas de hemodiluição, em estudo meta-analítico. Apesar de resultados positivos desta técnica em trabalhos diversos, destacam heterogeneidade inexplicável de resultados o que sugeriu inconsistência de benefícios em cujas razões incluíram-se amostras pequenas, ausência de protocolos transfusionais e considerações sobre morbimortalidade. O resultado do estudo foi considerado inconclusivo, apontando também a necessidade de novas e criteriosas pesquisas.

Outros procedimentos alternativos, citados por TRETIAK ${ }^{4}$ e colaboradores, para a redução de transfusões alogênicas de concentrados de hemácias, incluem a transfusão autóloga de sangue, equipamentos "cell savers", uso de eritropoietina recombinante, administração de drogas para redução de perda sangüínea durante cirurgias, além das já citadas emulsões de perfluorocarbono e soluções de hemoglobina. Estes autores desenvolveram estudo de custos sobre todo o ciclo do sangue, relacionado ao concentrado de hemácias, comparando custos entre transfusões heterólogas e autólogas entre 1.993 e 1.994 em oito hospitais do Canadá, levantam variáveis importantes determinantes do custo final de hemocomponentes, como local de coleta do sangue, se intra ou extra hospitalar, condições de saúde do doador, volume e tempo de coletas, número de transfusões, diferenças no porte dos diversos serviços, valores relacionados a custos dos profissionais envolvidos, entre 
outros. Os autores ressaltaram a importância da comparação do custo-efetividade de transfusões alogênicas com alternativas como transfusão autóloga, uso de eritropoietina recombinante, administração de aprotinina durante atos cirúrgicos, "cell savers" e outras técnicas e possibilidades de transferências de custos de um setor hospitalar para outro, aumentando o custo social global.

A II Guerra Mundial desencadeou produção de derivados do plasma sangüíneo consistente na precipitação de diversas proteínas plasmáticas, posteriormente submetidas a processos de purificação, concentração e inativação viral. Algumas dessas proteínas são produzidas atualmente por processos tecnológicos de recombinação de DNA, mostrando-se eficazes, bem toleradas, com menor risco de transmissão de doenças $\left(\mathrm{AABB}{ }^{10}\right.$ ).

Substitutos para o sangue, seus componentes e derivados, apesar das amplas pesquisas que se desencadeiam, ainda estão muito longe do alcance de resultados de eficácia e de produção necessários e compativeis com as práticas transfusionais atuais.

Para o financiamento de pesquisas, devem ser considerados critérios rigorosos com o intuito de evitar desperdicio de recursos em projetos mal conduzidos.

\subsection{Aspectos históricos e do direito sobre a hemoterapia}

No início do século $\mathrm{XX}$, a descoberta dos grupos sangüíneos por Karl Landsteiner permitiu o desenvolvimento de técnicas de transfusão, aperfeiçoadas de maneira importante durante as duas guerras mundiais (SANTOS ${ }^{5}$ ).

A II Guerra Mundial serviu de motivação e estímulo às primeiras campanhas de doação de sangue. A transfusão tornou-se rotina na prática médica, surgindo os primeiros bancos de sangue e a organização de sistemas de doação nos países da Europa Ocidental, alicerçados, desde seus primórdios, em doações altruístas e nãoremuneradas (AMORIM FILHO ${ }^{3}$ ).

No Brasil, na década de 1940, surgiram os primeiros bancos de sangue: o do Hospital Fernandes Figueira, no Rio de Janeiro em 1941 e o Banco de Sangue do Distrito Federal em 1945 (SANTOS ${ }^{5}$ ).

Em 1949 foi organizada a Associação dos Doadores Voluntários de Sangue do Rio de Janeiro que, depois, tornar-se-ia de caráter nacional - organização fundamental, embrião do sistema em vigor na atualidade -, defendendo as doações voluntárias não pagas, em confronto com bancos de sangue que viam, no sangue, recurso terapêutico com valor de mercado e que recrutavam doadores através de pagamento ${ }^{5}$.

A primeira lei a abordar questões do sangue foi a Lei Federal $n .{ }^{\circ} 1.075$, de 3 de maŕço de 1950, que dispensava do ponto, no dia de doação de sangue, o funcionário público civil ou militar que doasse sangue a banco mantido por organização estatal ou paraestatal ${ }^{11}$.

Em São Paulo, o Decreto n. ${ }^{\circ} 34.658$, de 13 de fevereiro de 1959, dispensava do ponto as doações voluntárias em bancos privados onde não houvesse bancos públicos, "se a entidade particular receptora não aplicar o sangue recebido mediante remuneração". A dispensa do trabalho se estendia por, no máximo, três vezes ao ano, com intervalo mínimo de 45 dias ${ }^{5}$. 
Até o ano de 1964 não houve qualquer regulamentação legal para as atividades relacionadas ao sangue, sendo que, neste período, ocorreu a proliferação de pequenos bancos de sangue privados, como negócio lucrativo, comprando sangue de doadores e o vendendo a hospitais, em geral sem controle de qualidade. Estabelecia-se padrão de banco de sangue comercial de pequeno porte, a que se referiu Pierre Cazal, em relatório apresentado em 1969, como consultor da Organização Mundial de Saúde ${ }^{5}$.

No Brasil, a primeira planta de produção de hemoderivados foi instalada pelo grupo Höechst, em Teresópolis, no Rio de Janeiro durante a década de 1950 . Os pequenos bancos passaram a vender parte de sua produção para o fracionamento industrial, implementando a lógica comercial já existente, de menor custo possível e baixa qualidade do sangue, de forma contrária à evolução tecnológica da hemoterapia que ocorria internacionalmente ${ }^{5}$.

A terapia através do sangue ganhou importância em meados da década de 1960, com progressos como aumento do tempo de estocagem do sangue, aprimoramento de testes pré-transfusionais, desenvolvimento das técnicas de cirurgia cardíaca, que demandava grande quantidade de sangue nos períodos perioperatórios e, também, a utilização rotineira dos componentes sangüíneos ao invés de sangue total, trouxe mais eficiência aos tratamentos e, ao mesmo tempo, evitavam a aplicação excessiva de sangue (LIMA ${ }^{12}$ ).

A Lei Federal n. ${ }^{\circ} 4.701$, de 28 de junho de 1965, cria a Comissão Nacional de Hemoterapia - $\mathrm{CNH}$, órgão normativo e consultivo, incumbido de promover medidas necessárias ao cumprimento dos preceitos da Política Nacional de Sangue, subordinado ao Ministério da Saúde, destacando-se o incentivo e o auxílio a organizações que promovessem aliciamento e utilização de doadores voluntários, que fornecessem sangue para transfusão gratuitamente, com a promoção de medidas para assegurar a utilização de sangue obtido por doação voluntária nas organizações oficiais, paraestatais e beneficentes e a adoção de medidas de apoio à proteção dos doadores não remunerados e que evitassem o abuso por questões econômicofinanceiras. Também tinha a incumbência de conceder autorização para exportação de derivados de sangue e fixar normas para sua eventual exportação, a finalidade de definir sistemas de organizações responsáveis pelo provimento adequado e distribuição de sangue e seus hemoderivados, primando pela doação voluntária de sangue, também de estabelecer medidas de proteção individual do doador e do receptor, de assegurar critérios para a destinação do sangue e dos hemocomponentes e assim garantir sua disponibilidade para transfusão, com a finalidade de constituir, como de interesse e segurança nacional, reservas hemoterápicas à disposição do Estado, também de disciplinar a atividade industrial relativa à produção de derivados do sangue e de incentivar a pesquisa científica relacionada ${ }^{13}$.

Em fevereiro de 1967 a CNH determinou que o exercício de atividades hemoterápicas dependeria de registro naquele órgão, junto ao Ministério da Saúde, com a finalidade de cadastro das entidades ${ }^{14}$ a serem classificadas em: Serviços de Hemoterapia, Banco de Sangue, Posto de Coleta, Agência Transfusional, Serviço Industrial de Derivados de Sangue e Posto de Suprimento. Além do regimento e do contrato social, para a efetivação do cadastro, era necessária a habilitação de profissional médico que poderia ser responsável por apenas um órgão executivo de atividade hemoterápica ${ }^{55}$. No mesmo ano, por Decreto Federal ${ }^{27}$ era vedada a exportação de sangue humano e hemoderivados (SERINOLLI ${ }^{16}$ ). 
As portarias da $\mathrm{CNH}$ tiveram pouco êxito, no propósito de disciplinar as atividades hemoterápicas, pelos problemas relacionados a sua execução. A necessidade de normalização relacionada ao sangue era evidente, no ano de 1967, e foram ditadas pela Comissão Nacional de Hemoderivados; mas, a execução das atividades, ficou a cargo das divisões de vigilância sanitária estaduais, desaparelhadas e sobrecarregadas, incapazes de realizar sua fiscalização de forma satisfatória. Ao mesmo tempo, o Instituto Nacional de Previdência Social (INPS) iniciava a compra de serviços de saúde, inclusive de sangue, para os hospitais públicos e particulares contratados, impulsionando o crescimento do número de pequenos bancos de sangue particulares.

Em 1975 foi publicada a Resolução $\mathrm{CNH}$ n. ${ }^{\circ} 1 / 75$, que especificava o emprego do sangue somente como meio terapêutico, profilático ou diagnóstico, testados laboratorialmente contra a hepatite $\mathrm{B}$, sifilis e Doença de Chagas, informações que deveriam constar dos rótulos das unidades doadas, assim como classificações imuno-hematológicas ${ }^{16}$.

Com a reforma do Ministério da Saúde, em 1976, a CNH foi transformada em "Câmara Técnica de Hemoterapia", deixando de determinar as diretrizes políticas relacionadas ao sangue que, em 1978, passou a ser função da Comissão de Articulação Ceme / Fiocruz - Comart (SANTOS ${ }^{5}$ ).

Em 1978, o Código Sanitário do Estado de São Paulo, em seu capítulo XIV, determinava as condições e disposições de área física para órgãos executivos de atividades hemoterápicas $\mathrm{e}$, no livro IX, a obrigatoriedade de os serviços de hemoterapia contarem com fichários atualizados dos doadores de sangue; os doadores deveriam ter as doações rejeitadas caso apresentassem falta de condições de saúde físicas ou mentais. $O$ sangue deveria passar por processos físicos ou químicos que o libertassem de agentes nocivos à saúde do receptor ${ }^{17}$.

Em 1980, instituia-se o Programa Nacional de Sangue do Ministério da Saúde (Pró-sangue) com a finalidade de evitar a especulação na coleta e distribuição de sangue, reordenando-a para a legítima finalidade social, estimulando a doação voluntária, não remunerada, e evitando as doações de sangue pelas populações marginalizadas dos grandes centros urbanos. Iniciava-se a implantação de hemocentros, formando a Rede Nacional de Centros de Hematologia e Hemoterapia (SANTOS ${ }^{5}$ ).

A criação do Pró-sangue pode ser vista como uma resposta oficial à insatisfação da sociedade organizada com o descontrole do sistema de sangue, os altos índices de doenças infecto-contagiosas diagnosticáveis na época, causas de contaminação transfusional, em particular a ocorrência da Doença de Chagas, também os primeiros casos de AIDS. Houve gradual polarização da opinião pública; contudo, as respostas institucionais foram lentas e de acordo com as condições regionais (SANTOS ${ }^{18}$ ).

Em 1985 é constituída a Vigilância Sanitária no Estado de São Paulo. Por problemas de qualidade, as bolsas de sangue nacionais, nesta época, foram recolhidas, após várias reuniões com grupos envolvidos com a questão. Este recolhimento promoveu o primeiro investimento em hemoterapia no Estado que passou a importar novas bolsas de sangue, inclusive fornecendo-as a hospitais privados.

Grandes discussões sobre os problemas do sangue ocorreram durante a $8^{\mathrm{a}}$ Conferência Nacional de Saúde, em 1986 e nos debates prévios às votações da 
Constituinte, em 1988, o controle do sangue seguiu os pólos sobre estatização/privatização. Seguindo a linha política de descentralização da saúde, os Estados iniciaram a formulação de políticas hemoterápicas, aumentando a fiscalização através das Vigilâncias Sanitárias ${ }^{18}$. Em 1986, instituiu-se em São Paulo a obrigatoriedade dos testes antiaids para fins hemoterápicos ${ }^{19}$.

A descentralização das políticas de hemoterapia para os Estados provocou controle e físcalização não uniformes dos serviços pelo país, com importantes diferenças regionais. As dificuldades e problemas continuavam, em todas as etapas do processo hemoterápico, faltavam dados estatísticos, a produção estava aquém das necessidades transfusionais do país, ainda com predomínio da iniciativa privada no setor.

A falta constante de doadores, decorrente de campanhas descontínuas e descoordenadas de captação, também a necessidade de controle e seleção de doadores, etapa fundamental do processo para obtenção de sangue de boa qualidade, mas que restringe a doação, agravavam ainda mais a falta de sangue ${ }^{19}$. Em 1987 a oferta era estimada, em relação às demandas, em pouco mais de $10 \%$ para o Estado de São Paulo e 4,5\% para o Brasil; mesmo as doações de reposição, exigidas de amigos e parentes de pacientes internados em hospitais, eram insuficientes e correspondiam, em 1987 , a $82 \%$ do total de doações recebidas pela rede oficial de Hemocentros (FERREIRA ${ }^{20}$ ), com o agravante de ordem ética que envolve este tipo de doação, pelo aspecto coercitivo que possibilita (LIMA ${ }^{12}$ ).

Em outubro de 1987, considerando a incidência crescente da AIDS e a necessidade de assegurar o controle de qualidade do sangue transfundido, é elaborada pela Comissão Interministerial de Planejamento - CIPLAN, a Resolução Interministerial n. ${ }^{\circ} 009$, que restringe doações remuneradas e provenientes de colônias penais e de recuperação de drogados, expostos a fatores de risco ou com manifestações de doenças, também abordando questões relativas à ética médica, incluindo-se o sigilo sobre soropositividade, responsabilidade sobre notificação epidemiológica e normas de biossegurança ${ }^{21}$.

Em janeiro de 1988 é promulgada lei que institui a obrigatoriedade do cadastramento de doadores de sangue e realização de exames laboratoriais para detectar infecções por Hepatite B, Sífilis, Doença de Chagas, Malária e AIDS. Havendo contaminação, o sangue do doador deveria ser desprezado; todo o material utilizado no processamento do sangue, da seleção do doador à transfusão, deveria ser descartável ${ }^{22,23}$.

Em março de 1988, o Pró-sangue foi substituído pelo Plano Nacional de Sangue e Hemoderivados - Planashe (FERREIRA ${ }^{20}$ ). Considerou-se ter havido apenas troca de nomes, com poucas alterações de conteúdo ou mudanças profundas, com o propósito de criar "fato novo" no cenário hemoterápico brasileiro, estimulado pelos movimentos sociais desencadeados pelo surgimento da AIDS. Permanecia a estrutura centralizada e vertical, ampliava a possibilidade de captação de recursos financeiros entre ministérios e externos e excluia o setor privado responsável na formulação de políticas (SANTOS ${ }^{18}$ ).

A Constituição Brasileira de $1988{ }^{24}$, em seu Artigo 199, como expressão de documento político que transforma em lei os objetivos da sociedade ${ }^{25}$ tem, ao "vedar todo o tipo de comercialização", a consolidação da atuação dos movimentos sociais, forças econômicas e politicas sobre a questão do sangue. Segundo DALLARI ${ }^{25}$, a opção pela não aceitação - em qualquer hipótese - da comercialização do corpo 
humano ou parte dele, implica considerações econômicas que muitas vezes afrontam a ética sanitária, acrescentando que, sem dúvida, existe mercado para os produtos decorrentes das pesquisas biológicas, sendo inegável que a participação em algumas pesquisas acarreta ônus financeiro para os pesquisados. Diz ainda que, a conceituação econômica de bem faz com que, devido à escassez, os órgão e tecidos humanos, que satisfazem necessidades tanto de tratamento médico como de pesquisa para o desenvolvimento de medicamentos, permitem que lhe determine valor de mercado. Reconhecendo a importância social, por exemplo, da doação de órgãos e tecidos humanos, determina que tal noção seja amplamente disseminada, possibilitando a todos - os pesquisadores - a racionalização da ética sobre a matéria.

A regulamentação do $\S 4^{\circ}$ do art. 199 da Constituição Federal ${ }^{24}$ relativo à coleta, processamento, estocagem, distribuição e aplicação do sangue, seus componentes e derivados, estabelecendo o ordenamento institucional indispensável à execução adequada dessas atividades, entre outras providências, acontece somente em março de 2001, com a Lei 10.205 , de 21 de março de $2001{ }^{28}$ que não considera como comercialização a cobrança de valores referentes a insumos, materiais, exames sorológicos, imunoematológicos e demais exames laboratoriais definidos pela legislação competente, realizados para a seleção do sangue, componentes ou derivados, bem como honorários por serviços médicos prestados na assistência aos pacientes e aos doadores. Destaca-se que os reagentes e insumos para diagnóstico que são produtos ou subprodutos de uso laboratorial oriundos de sangue total ou de outras fontes integram o conteúdo da Lei.

Em setembro de 1990 é baixada a Lei 8.080, Lei Orgânica da Saúde, que regulamenta dispositivo da Constituição Brasileira e que inclui no Sistema Único de Saúde (SUS) as instituições públicas de sangue e hemoderivados; inclui, igualmente, nesse campo, a formulação de políticas relacionadas e, no âmbito administrativo, atribuição de implantar "Sistema Nacional de Sangue, Componentes e Derivados". À direção estadual do SUS compete coordenar a rede de Hemocentros e, aos municípios, a gestão. A participação dos serviços privados, de forma complementar, deve ser formalizada mediante contratos e convênios ${ }^{26}$.

Questão muito discutida, após a expressão constitucional descrita, era se essa não comercialização implicaria na estatização do setor de hemoterapia.

Com o intuito de melhorar a qualidade do sangue a ser transfundido, evitando a propagação de doenças, normalizar e uniformizar os processos da coleta à transfusão sangüínea e os procedimentos de segurança, determinando responsabilidades e possibilitando a capacitação de pessoal, baixou-se a Portaria n. ${ }^{\circ}$ 721/GM, em agosto de 1989, disciplinando Normas Técnicas, exaustivamente debatidas e aprovadas por "representantes qualificados" em hemoterapia, organizadas e consolidadas pela Divisão Nacional de Sangue e Hemoderivados DINASHE ${ }^{29}$. A Portaria apresentava detalhamento importante sobre a triagem clínica do doador, visando a proteção do receptor e do próprio doador. Na proteção do receptor, ainda eram realizados testes, na triagem sorológica do sangue coletado, havendo a obrigatoriedade nos testes laboratoriais sorológicos para hepatite B, HIV, dois testes diferentes para a Doença de Chagas, testes para malária nas regiões endêmicas e pesquisa de citomegalovírus (CMV), quando o receptor do sangue tivesse sido submetido a transplante de órgãos.

A década de 1980, então, foi de grandes mudanças, no Brasil, para a hemoterapia. As discussões passaram a ter interesse "não-técnico", não- 
especializado, claramente posterior ao surgimento da epidemia de AIDS, ganhando dimensão nitidamente ideológica e político-partidária, chamada "politização do sangue", diferentemente do contexto internacional que já discutia questões sobre altruísmo e doenças transfusionais havia 20 anos (SANTOS ${ }^{18}$ ).

Voltando ao assunto sobre hemoterapia, a legislação relacionada, iniciada em 1950, ganhou algum formato a partir de 1965, com a Comissão Nacional de Hemoterapia. Sua aplicação, contudo, não foi efetiva, sendo que houve reedições, como nas questões referentes a cadastros de doadores e responsabilidade técnica pelas unidades hemoterápicas. $\mathrm{Na}$ década de 1980, com o surgimento da AIDS, as discussões sobre a importância do sangue ganharam conotação política, além de técnica, com grande impulso, que culminou na $8^{\mathrm{a}}$ Conferência Nacional de Saúde, na Constituição Federal de 1988, cristalizando-se na Portaria MS n. ${ }^{\circ} 1376 / 93$, que detalha a organização dos serviços e técnicas necessárias ao seu funcionamento. As legislações complementares implicam em restrições maiores ao doador nas triagens clínica e sorológica sendo que o desafio é de adaptar os recursos financeiros às novas técnicas laboratoriais emergentes, de custo elevado ${ }^{6}$.

Em novembro de 1993 é publicada a Portaria n. ${ }^{\circ} 1376$ aprovando alterações na Portaria n. ${ }^{\circ} 721 / 89 / \mathrm{GM}$, sendo alterada a instância normativa para Coordenação de Sangue e Hemoderivados (COSAH), em substituição à Divisão Nacional de Sangue e Hemoderivados, responsável pela interpretação e revisão periódica das Normas Técnicas aprovadas ${ }^{7}$. Apresenta detalhamento ainda maior, incluindo-se normas de controle de qualidade. Na triagem sorológica, há obrigatoriedade dos testes para hepatite B e C, AIDS, sífilis, Doença de Chagas, a dosagem da TGP/ALT, anti-HBC e anti-HTLV - I/II ${ }^{8}$ e malária, em regiões endêmicas. Em outubro de 1996, foram acrescentados os testes anti-HIV-I e anti-HIV-II às Normas Técnicas vigentes ${ }^{9}$.

No Estado de São Paulo, é criada a Rede Estadual de Hematologia e Hemoterapia, HEMO-REDE, em janeiro de 1991, conceituando e estabelecendo os Hemocentros, Postos de Coleta de Sangue, definidos por ato do Secretário da Saúde e Agências Transfusionais, definidas pelos Hemocentros e Núcleos de Hematologia e Hemoterapia, em articulação com os hospitais. Definida a coordenação da HEMOREDE no âmbito central e no regional ${ }^{32}$. A organização dos Núcleos de Hematologia e Hemoterapia e das Unidades Sorológicas foi estabelecida em junho de 1992, quando foram determinadas estrutura, atribuições e competências. Tanto os Núcleos de Hematologia e Hemoterapia quanto as Unidades Sorológicas subordinavam-se aos Escritórios Regionais de Saúde do Estado de São Paulo ${ }^{33}{ }^{34}$.

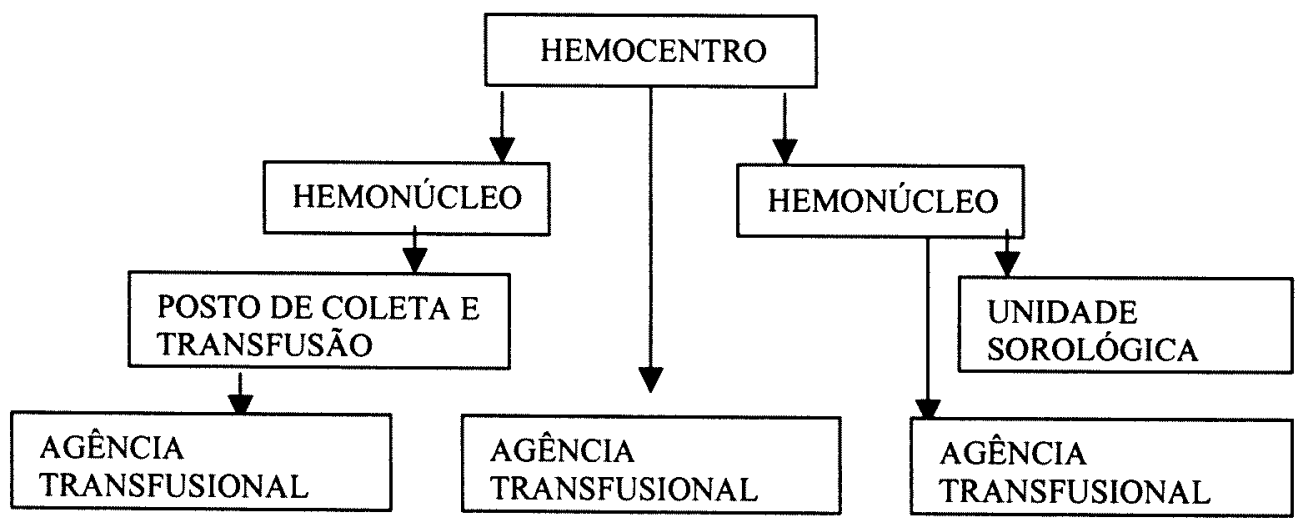

Figura 1 Hemorrede 
Em março de 1994, era aprovada a instrução normativa estadual que indicava o fluxo de "Cadastro de Hemoterapia", precedida de preenchimento da "Ficha de Cadastro Ambulatorial" a partir da qual se deveria proceder à inspeção sanitária pelo Grupo Técnico de Vigilância Sanitária (GTVS) e encaminhadas ao "Grupo de Coordenação Técnica de Hemoterapia" das Coordenações Regionais de Saúde do Estado de São Paulo ${ }^{35}$.

Em agosto de 1994, na consolidação do processo de descentralização, é definido o Sistema Nacional de Vigilância Sanitária, ditando normas para a execução dos serviços de Vigilância Sanitária das diversas esferas de governo no SUS, visando à organização do sistema, à formação de rede laboratorial oficial para Controle de Qualidade e implantar o Sistema Nacional de Informações em Vigilância Sanitária, incluindo o sangue e hemoderivados no seu exercício, ficando o Estado com a competência de implementar serviços e prestar apoio técnico ${ }^{36}$.

A necessidade de se estabelecer padrões de referência para controle de qualidade das reações sorológicas executadas pelas Unidades Hemoterápicas na triagem de doadores de sangue gerou a instituição de "Programa Nacional de Controle de Qualidade Externo em Sorologia", PNCQES, em setembro de $1996^{37}$, coordenado pela Secretaria de Vigilância Sanitária do Ministério da Saúde e em consonância com as diretrizes e procedimentos estabelecidos pela Coordenação do Sangue e Hemoderivados - COSAH, passando a ser mais abrangente em 1997, com a denominação de "Programa Nacional de Controle de Qualidade Externo em Sorologia e Imunohematologia" 38 .

Em 1996, segundo SERINOLLI ${ }^{39}$, o governo brasileiro atuou energicamente na melhoria da qualidade do sangue, implantando o Programa Nacional de Inspeções em Unidades Hemoterápicas, envolvendo quatrocentas unidades, responsáveis por $90 \%$ do sangue coletado pelo Sistema Único de Saúde ${ }^{40}$.

Em estudo realizado entre março e junho de 1996, sobre "Roteiro de Inspeção em Unidades Hemoterápicas" ${ }^{41}$, de acordo com critérios estabelecidos pela Portaria MS n. ${ }^{\circ} 1376 / 937$, concluiu-se que $38,54 \%$ das unidades inspecionadas foram consideradas insatisfatórias na execução de normas técnicas, destacando como problema a falta de recursos financeiros do Pró-sangue, em São Paulo, baixa remuneração de funcionários e deficiências no sistema de informações, dispersando recursos e dificultando o controle de qualidade ${ }^{39}$.

No Estado de São Paulo, em novembro de 1997, foi feito treinamento, organizado pela Coordenadoria dos Institutos de Pesquisa - Centro de Vigilância Sanitária, para capacitação de profissionais para a fiscalização e controle de serviços hemoterápicos, muitos dos quais foram credenciados para se fazer representar pela Secretaria de Vigilância Sanitária do Ministério da Saúde em inspeções pelo Programa Nacional de Inspeções em Unidades Hemoterápicas (PNIUH). Foram credenciados 158 técnicos dos serviços estaduais, sendo 49 pelo Estado de São Paulo 42 .

Com a intenção de renovar os cadastros dos serviços que datavam de 1993, foi feita ficha de "Cadastro de Hemoterapia", com novo formato, que deveria ser aplicada no ano de 1998, visando à implantação de Sistema de Informação de Hemoterapia, SIS-HEMO. No entanto, em maio de 1999, a Equipe Técnica de Hemoterapia do Centro de Vigilância Sanitária de São Paulo ainda não dispunha de dados cadastrais confiáveis, relatando que "certamente não foram cadastrados todos os serviços existentes" naquele período e que, considerando os dados cadastrais de 
1993 e os atualizados, concluía que entre 32 e $47 \%$ dos serviços hemoterápicos tiveram inspeções informadas durante o ano de $1998{ }^{43}$, retratando a manutenção, crônica, dos problemas estatísticos, já referidos por SANTOS ${ }^{18}$, em 1992.

O Ministério da Saúde, em 28 de maio de 1998, lançou, através do Presidente da República, doze Metas Mobilizadoras para a saúde, em doze projetos sobre estratégias para atingi-las. Uma destas doze metas seria de garantir a qualidade do sangue transfundido. O objetivo era de "envolver a sociedade brasileira, levando-a a participar ativamente do processo da doação de sangue de forma consciente e responsável, através de ações educativas e de mobilização social, visando a garantia da qualidade do sangue, componentes e derivados" considerando que "apesar dos avanços alcançados pela hemoterapia brasileira a partir da criação do Pró-sangue, desníveis tecnológicos e, sobretudo, sócio-econômicos e culturais, fazem com que, contrastando com serviços de excelência técnico-científica de nível internacional, identifiquemos, ainda hoje, a prática da transfusão braço-a-braço, sem qualquer controle documental, imunohematológico ou sorológico, colocando setores da população sob risco ao receber uma transfusão de sangue". A meta proposta pelo Ministério da Saúde é de "Sangue com garantia de qualidade, em todo o seu processo, até 2003".

Em 28 de janeiro de 1999 foi instituída Autarquia Especial pela Lei Federal n. ${ }^{\circ}$ 9.782, denominada Agência Nacional de Vigilância Sanitária - ANVISA, tendo como missão, em relação à questão do sangue, "promover a proteção e a recuperação da saúde da população, coordenando ações que disponibilizem sangue $e$ hemoderivados com garantia de qualidade em todo o seu processo e em quantidade suficiente para suprir a demanda do país", assumindo a continuidade para o alcance da Meta Mobilizadora.

Através de Contrato de Gestão, documento oficial firmado entre o Ministério da Saúde e a ANVISA, houve o estabelecimento de que a ANVISA é responsável pelo controle sanitário da produção e da comercialização de produtos e serviços submetidos à vigilância sanitária, dos ambientes, dos processos, dos insumos e das tecnologias. Além desses a ANVISA ainda exerce controle de portos, aeroportos e fronteiras e a interlocução junto ao Ministério das Relações Exteriores e instituições estrangeiras para tratar de assuntos de cunho internacional na área de vigilância sanitária. O Contrato prevê duração de três anos, podendo ser renovado em períodos sucessivos de três anos, no interesse de ambas as partes.

Em novembro de 1999, o planejamento, a coordenação e a avaliação da execução das atividades do Programa Nacional de Sangue e Hemoderivados, subprogramas e projetos da área técnica relacionada passaram a ser executados pela Gerência Geral de Sangue e Hemoderivados da Diretoria de Serviços e Correlatos da Agência Nacional de Vigilância Sanitária ${ }^{44}$.

Em dezembro de 2002 foi revogada a Portaria Conjunta n. ${ }^{\circ} 1376$ SVS/MS SPS/MS de 13 de novembro de 1993, substituída pela Resolução da Diretoria Colegiada-RDC n. ${ }^{\circ} 343$, de 13 de dezembro de $2002^{82}$.

As considerações do "caput" da nova legislação incluíram, como inovação, a importância de compatibilizar a legislação nacional com os instrumentos harmonizados no âmbito do Mercosul, Res. GMC n. ${ }^{\circ} 42 / 00$.

À legislação anterior, acrescentou-se a possibilidade de o doador de sangue manter doações regulares de até duas vezes ao ano, entre 60 e 65 anos. 
Doadores, antes rejeitados por história de transfusão nos últimos dez anos, em seus antecedentes hematológicos poderão doar sangue após doze meses da recepção transfusional.

Registros dos candidatos à doação de sangue devem ser conservados por dez anos, contra cinco ditados pela legislação anterior. Procedimentos de recepção, triagem e coleta de sangue, assim como a atenção ao doador que apresentar reações adversas, devem estar contidos em manual de Procedimentos Operacionais Padronizados, não exigido anteriormente.

O controle de qualidade de hemocomponentes, assim como a definição de suas diversas apresentações, são normalizados. Firmados em dez anos os registros e, seis meses, a manutenção de plasmateca.

$\mathrm{Na}$ rotulagem, além das informações de conteúdo e de testes realizados, incluem-se informações ou instruções para transfusão.

Há detalhamento muito maior relacionado aos procedimentos de obtenção de componentes por aférese, também exigências quanto a programa de capacitação profissional, até de controle de equipamentos com manutenção preventiva determinada.

A legislação atual prevê a extensão das exigências nos procedimentos de hemoterapia, com maior detalhamento e determinando mais responsabilidade aos gerentes. As alterações traduzem as necessidades da sociedade e suas exigências políticas impostas no final da década de 1980 e na década de 1990.

Ainda que seja justa e necessária, significa suplementação dos custos de produção, aplicação e controle de hemocomponentes.

\subsection{O Hemocentro de Botucatu: história e objetivos}

A Faculdade de Ciências Médicas e Biológicas de Botucatu - FCMBB foi criada em 1962 (Lei n. ${ }^{\circ} 6.860$, de 22 de julho de 1962). Suas atividades no núcleo de Botucatu tiveram seu início em abril de 1963, com sua instalação. A instituição vinculada, na época, ao Conselho de Ensino Superior do Estado de São Paulo (CESESP), congregava profissionais da área da saúde e oferecia quatro cursos: Medicina, Biologia, Medicina Veterinária e Agronomia (DEFFUNE \& ALVARADO ${ }^{45}$ ).

Até o início da década de 70 as atividades docentes foram concentradas no sentido de implantar os cursos e criar infra-estrutura indispensável para ministrá-los. $\mathrm{Na}$ área médica, especificamente, os esforços foram canalizados para os serviços de ambulatórios, enfermarias e unidades técnicas e administrativas do Hospital de Clínicas e dos Departamentos ${ }^{45}$.

Entre as idéias que direcionavam a criação e implantação da FCMBB destacavam-se ${ }^{46}$ :

"bem formar homens e médicos";

"... mentalidade aberta a todas as verdades e voltada a solução de problemas";

“... aluno se tornasse cidadão consciente e profissional competente, profissional com condições pessoais para prosseguir, fora da faculdade, os estudos e pesquisas nela iniciados e capaz de integrar a vultosa soma de conhecimentos...";

“... atenção voltada um pouco mais para o doente e não só para a doença...";

“... transformação do ensino clínico de informativo para formativo". 
A integração em vários níveis indicando avanços no sentido da interdisciplinaridade, a contratação em tempo integral dos docentes para que houvesse dedicação exclusiva às atividades de ensino, feitas em pequenos grupos, e de forma importante às pesquisas com maior aproximação junto ao corpo discente, eliminando barreiras, aumentando rendimento e produtividade, seriam formas de alcançar as propostas iniciais, destacando o "Plano de Ensino Médico na Faculdade de Botucatu, em São Paulo" elaborado e publicado em 1966 pelo Prof. J. E. Dutra de Oliveira ${ }^{47}$. Vale destacar as questões relacionadas ao ensino integrado entre as várias disciplinas e a característica de priorização do ensino sobre a assistência. Com a criação da Universidade Estadual Paulista "Júlio de Mesquita Filho" pelo Decreto Lei n. ' 952 de 30 de janeiro de 1976, houve desmembramento das faculdades em: Faculdade de Medicina, Instituto Básico de Biologia Médica e Agrícola, Faculdade de Medicina Veterinária e Zootecnia e Faculdade de Agronomia.

Na Faculdade de Medicina, especificamente, mudaram-se os objetivos com relação ao ensino integrado, as disciplinas aumentaram em número com o surgimento cada vez maior das especialidades; as idéias iniciais descaracterizaramse, hoje muito menos explicitas e até desconhecidas, principalmente por docentes contratados recentemente, residentes, alunos e técnicos (ANJOS ${ }^{48}$ ).

Em março de 1998, o Grupo Técnico de Desenvolvimento de Recursos Humanos - GTDRH, trabalhando na linha de Desenvolvimento Organizacional, organizou seminários com o objetivo de determinar a "visão, valores e missão da Faculdade de Medicina de Botucatu", pressentindo a existência de objetivos diferentes entre as diversas áreas da Faculdade e do HC, o comportamento de "emergência de pronto socorro", o crescimento desordenado e nunca discutido, a falta de projetos de trabalho de chefias, todos característicos da falta de planejamento; também o conflito entre as questões acadêmicas e técnicoadministrativas e a falta de unidade de ensino entre os diversos Departamentos $\left(\mathrm{ANJOS}^{48}\right)$.

Apesar dos esforços do GTDRH, desde então, a definição da missão ainda não havia sido concluída até o final de 1999 , abordando, separadamente, questões sobre ensino, pesquisa, assistência e quadro funcional.

Em 1967 foi implantado sistema de captação de doadores e coleta de sangue pelo Prof. Carlos Gomes de Araújo, docente da Disciplina de Urologia do Departamento de Cirurgia da Faculdade de Ciências Médicas e Biológicas de Botucatu (FCMBB), com a finalidade de possibilitar a realização de cirurgias no Hospital de Clínicas (HC). Referido sistema envolvia o Serviço Social Médico do $\mathrm{HC}$, na captação de doadores, solicitados aos pacientes internados com o intuito de repor ou manter estoques de sangue, embrião do sistema existente hoje.

Em 1976, quando a FCMBB foi integrada à UNESP, a então Disciplina de Urologia constituiu, na nova organização, o Departamento de Urologia. A Hemoterapia, mantendo-se ligada ao Prof. Carlos Gomes de Araújo, organizou-se como Disciplina no Departamento constituído.

A aquisição de equipamento denominado "centrífuga refrigerada", em meados de 1979, constituiu marco histórico relevante na evolução da Hemoterapia na Faculdade de Medicina: o sangue deixou de ser coletado em frascos de vidro, passando a ser coletado em bolsas plásticas e estas passaram a ser centrifugadas ao invés de decantadas, por gravidade, como ocorria com os frascos, para a obtenção de 
hemocomponentes. A centrifugação refrigerada ampliou a obtenção de hemocomponentes, até então, restritos a concentrados de hemácias.

Estudo sobre a implantação de um Centro de Hematologia e Hemoterapia, com a participação dos Departamentos de Clínica Médica e de Urologia, iniciou-se em 1982, quando foi elaborada proposta de regimento interno e projeto de nova planta física.

Em agosto de 1982, os responsáveis pelas disciplinas de Hematologia (Departamento de Clínica Médica) e Hemoterapia (Departamento de Urologia), solicitaram a filiação da Faculdade de Medicina ao Pró-sangue, junto ao Ministério da Saúde e, em 14 de setembro do mesmo ano foi criado o HEMOCENTRO DE BOTUCATU, integrado ao Pró-Sangue do Ministério da Saúde, segundo ofício $\mathrm{SG} / \mathrm{GAB} /$. $^{\circ} 02982$ do Secretário Geral do Ministério da Saúde, sendo então liberadas verbas para sua implantação.

Em 6 de outubro de 1982, a Congregação da Faculdade de Medicina de Botucatu deliberou favoravelmente à filiação, sendo referendada às disciplinas de Hematologia e Hemoterapia a coordenação do Hemocentro.

A Portaria UNESP n. ${ }^{\circ} 382$, de 6 de dezembro de 1983, criou a DIVISÃO HEMOCENTRO, subordinada à Supervisão do Hospital de Clínicas da Faculdade de Medicina de Botucatu atendendo, inicialmente, o Hospital de Clínicas, nas áreas de Hemoterapia e Hematologia, assim como desenvolvendo programas de formação de recursos humanos médicos (graduação e residência médica), para-médicos (biólogos, farmacêuticos e biomédicos), nas áreas de Hematologia, Hemostasia e Hemoterapia, de acordo com o programa da FUNDAP de aprimoramento. Ao curso de graduação, continuavam sendo oferecidas as disciplinas de Hematologia e Hemoterapia, separadamente. No entanto, para a formação de médicos residentes, consolidou-se programa único de Residência Médica em Hematologia e Hemoterapia, sendo oferecidas três vagas anuais. Apesar de a Residência Médica ser unificada, as disciplinas de Hematologia e de Hemoterapia permanecem distintas e vinculadas, respectivamente, aos departamentos de Clínica Médica e de Urologia.

Entre 1985 e 1986 foram instalados e equipados os Laboratórios de Hemostasia, Sorologia e Bioquímica Eritrocitária, com investimentos na área física, em equipamentos e em pessoal especializado.

Em 1987 foram iniciadas as Coletas Externas de sangue.

Em 1990, a Divisão Hemocentro iniciou projeto de implantação na área de Biotecnologia, para tanto, necessitou-se de profissional com experiência internacional na área de produção de anticorpos monoclonais e na área de qualidade e biossegurança.

Em 1991, com a aprovação da congregação da Faculdade de Medicina, iniciase o processo de contratação de pesquisador, que se consolida em agosto de 1992. As atividades referentes à biotecnologia são iniciadas e, de forma concomitante, as de controle de qualidade, consolidando evolução técnica importante. O Laboratório de Biotecnologia produz inúmeros anticorpos monoclonais anti-eritrocitários, com tecnologia nacional, que substituem reativos policlonais anteriormente adquiridos no mercado privado sempre com custo muito superior (DEFFUNE \& ALVARADO ${ }^{45}$ ). Além da questão do avanço tecnológico levou-se em consideração que reagentes monoclonais são biosseguros, não expõe os técnicos, repetidamente, a material biológico humano potencialmente contaminado. $\mathrm{O}$ uso de reagentes policlonais humanos feriam princípios éticos, também dava margem ao questionamento sobre a 
legislação brasileira que proibia a comercialização de sangue, componentes e derivados, já que, naquela época, a constituição federal ainda não havia sido regulamentada com relação a este aspecto.

As mudanças de área física, conforme projeto inicial de 1982, foram concretizadas apenas em 1992, inclusive para alocar os laboratórios descritos. $\mathrm{Na}$ época, já mostrava sinais de ter espaços insuficientes para atender às atividades e às necessidades existentes.

Em 1994, a Divisão Hemocentro foi ampliada pela instalação de laboratório de Biologia Molecular, para diagnóstico e prevenção de doenças, integrante do projeto Genoma - Câncer da FAPESP.

Em 1999, importante projeto de ampliação e reforma da estrutura física e aquisição de equipamentos, apresentado ao Ministério da Saúde, é aprovado, são obtidos os recurso e iniciadas as obras no ano de 2000 , concluídas ainda que parcialmente, no ano de 2001: projeto REFORSUS.

No ano de 2001 iniciou-se implantação de técnicas de biologia molecular em diversos laboratórios do Hemocentro em prosseguimento a processo revolucionário, pois substitui métodos sorológicos - de incorporação tecnológica.

No dia 6 de outubro de 2001 houve reunião, fora do horário habitual de trabalho, sobre o tema "Divisão Hemocentro: Análise do Presente e Planejamento do Futuro" com a participação de 55 pessoas, correspondentes a $53 \%$ dos profissionais, dentro de metodologia participativa de trabalho, onde foram abordados três temas que passaram pelas etapas de criação ou de reflexão, com posterior exposição coletiva das idéias e discussão. Os temas abordados incluíram relacionamentos pessoais intersetoriais e intra-setoriais, fluxo de recursos materiais e recursos humanos, tendo sido descritos cenários atuais e visão dos cenários futuros ${ }^{74}$.

No organograma vigente, a Divisão Hemocentro encontra-se diretamente subordinada à Supervisão do Hospital de Clínicas e, esta, à Diretoria da Faculdade de Medicina. Subordinam-se à Divisão Hemocentro: a Seção Técnica de Desenvolvimento Diagnóstico e Controle de Qualidade, a Seção de Hematologia, a Seção Técnica de Hemoterapia e a Seção Técnica de Quimioterapia.

A Divisão Hemocentro de Botucatu, segundo DEFFUNE \& ALVARADO ${ }^{45}$, tem como finalidade a prestação de serviços, pesquisa e o desenvolvimento de processos biotecnológicos na área de hematologia e hemoterapia.

$\mathrm{O}$ estímulo à doação de sangue em Botucatu e nos municípios da região é descrito por LIMA $^{49}$ como a finalidade do Setor de Captação e Atendimento aos Doadores de Sangue.

ANJOS ${ }^{6}$ observa que, o cerne de toda a organização, tanto da Faculdade de Medicina, quanto do Hospital de Clínicas e da Divisão Hemocentro passaria pela definição precisa da missão e dos objetivos da instituição e que a implicação imediata seria o surgimento de objetivos e finalidades circunstanciais, de acordo com necessidades apresentadas de momento, sem a determinação das atribuições e da competência de cada nível hierárquico, não formalizadas para a Divisão Hemocentro naquele momento.

A Divisão Hemocentro, ainda segundo ANJOS ${ }^{6}$, vinha desenvolvendo normas e rotinas de trabalho, padronização de técnicas e controle de qualidade, dispostos em manuais, para seus diversos setores e laboratórios, ressaltando a probabilidade de ser o único local de ocorrência, como processo, dentro da Faculdade de Medicina. 
As metas do Hemocentro, como integrante da Hemo-rede, foram as definidas pelo Ministério da Saúde através do "Programa Nacional de Doações Voluntárias de Sangue" que incluía, até o ano de 2003:

a) tornar $4 \%$ da população, com idade entre 18 e 65 anos, doadora voluntária de sangue;

b) aumentar em $80 \%$ a participação dos doadores espontâneos em relação ao total de doadores da Hemo-rede;

c) aumentar em $6 \%$ ao ano a participação dos doadores habituais em relação ao total de doadores da Hemo-rede;

d) aumentar em $6 \%$ a participação da população feminina, com idade entre 18 e 60 anos, na doação voluntária de sangue, em relação ao total de doadores da Hemorede;

e) aumentar em $6 \%$ ao ano a participação da população jovem, com idade entre $18 \mathrm{e}$ 28 anos, na doação voluntária de sangue, em relação ao total de doadores da Hemorrede;

f) reduzir em $50 \%$ a taxa de inaptidão clínica na Hemo-rede;

g) reduzir em $50 \%$ a taxa de inaptidão sorológica.

A inaptidão clínica, também chamada rejeição clínica, está relacionada com a impossibilidade temporária ou definitiva registrada na triagem clínica do candidato à doação de sangue.

A inaptidão ou rejeição sorológica está relacionada com a detecção, nos testes sorológicos realizados com o sangue do doador, após a doação, que resultam reagentes e que têm, por conseqüência, o descarte das bolsas coletadas.

A questão tecnológica é determinante dos caminhos, mesmo por uma questão de sobrevivência do Hemocentro, ante as circunstâncias que se apresentavam de desenvolvimento técnico. O projeto Genoma - câncer, os laboratórios de biotecnologia e de carga viral são exemplos do rumo adotado.

\section{Estrutura e Processos}

Parte dos recursos materiais, tanto equipamentos quanto e, principalmente, reformas e construções na formação do Hemocentro provêm de financiamentos de projetos de pesquisa e projetos governamentais. Eventualmente, tais recursos financiam material de consumo utilizado em concomitância às atividades rotineiras. Destaca-se a reforma e ampliação do Hemocentro através de projeto apresentado ao REFORSUS, no ano de $2000^{81}$, como descrito anteriormente, que inclui as áreas fisicas destinadas à recepção, triagem clínica e coleta, também praça de alimentação para o doador de sangue.

Equipamentos novos, para a sala de coleta de sangue, como cadeiras automáticas, seladora, homogeneizadores e condicionadores de ar foram adquiridos no ano de 2003 com recursos de reserva de pesquisa.

O repasse, através de convênio entre o Hospital das Clínicas da Faculdade de Medicina e o Sistema Único de Saúde - SUS, garante a outra parte dos recursos, em geral utilizados para custeio de materiais de consumo. Estes recursos são recebidos por uma fundação, a Fundação para o Desenvolvimento Médico e Hospitalar - 
FAMESP, que repassa $40 \%$, aproximadamente, ao Hemocentro. Com estes recursos são pagos 17 dos 89 trabalhadores: 11 através da Fundação e 6 em contratos temporários de prestação de serviços.

A universidade contribui, através da Faculdade de Medicina, para uma de suas unidades, o Hospital das Clínicas, com o contrato de 54 servidores públicos, que prestam serviços ao Hemocentro, ainda arcando com despesas de custos indiretos como manutenção predial, água, luz, telefone, etc. e, ainda com fatia orçamentária de aproximados $\mathrm{R} \$ 45.000,00$ anuais.

Mesmo com as diversas fontes geradoras de recursos, o Hemocentro acumula dívida aproximada de meio milhão de reais (cerca de US\$170.000,00), com a Fundação, conforme divulgação, realizada aos trabalhadores do Hemocentro, em 5 de janeiro de 2004 (FAMESP - Sistema de Controle de Despesas dos Departamentos - Hemocentro). Algumas das possíveis razões para este acúmulo seriam o corte gradual de subsídios como a interrupção do fornecimento de bolsas de sangue e de testes sorológicos pela Secretaria Estadual de Saúde e pelo governo federal; muitos dos materiais de consumo são importados, cujos preços acompanham a variação do dólar.

O Hemocentro conta com 89 trabalhadores, sendo 54 servidores públicos, 18 trabalhadores contratados pela Fundação, sendo 11 pagos com recursos do Hemocentro e 7 com recursos da Supervisão do Hospital das Clínicas. Outros 9 trabalhadores são servidores públicos estaduais comissionados da Direção Regional de Saúde - DIR XI e, ainda, 2 trabalhadores prestam serviços, contratados pelo Hospital "Amaral Carvalho" de Jaú. Prestam serviços autônomos 6 trabalhadores temporários. As atividades de limpeza são realizadas por empresa contratada, constituindo grupo de trabalhadores contratados no regime da Consolidação das Leis do Trabalho - CLT.

O nível de escolaridade dos trabalhadores é de 53,9\% universitários, $44,9 \%$ com nivel médio e $1,2 \%$ de nível elementar. As proporções são semelhantes às relatadas por ANJOS ${ }^{6}$, referindo-se a agosto de 1999 . Vale destacar que $54,2 \%$ dos profissionais de nível universitário têm, no mínimo, especialização ou mestrado.

A distribuição apresentada dos trabalhadores evidencia a ausência de padrão de lotação adequado para a Divisão Hemocentro, que se pode considerar frágil.

O grande número de "patrões" impossibilita gerenciamento adequado dos trabalhadores e pode gerar insatisfações subliminares devidas às diferenças de vencimentos para funções semelhantes.

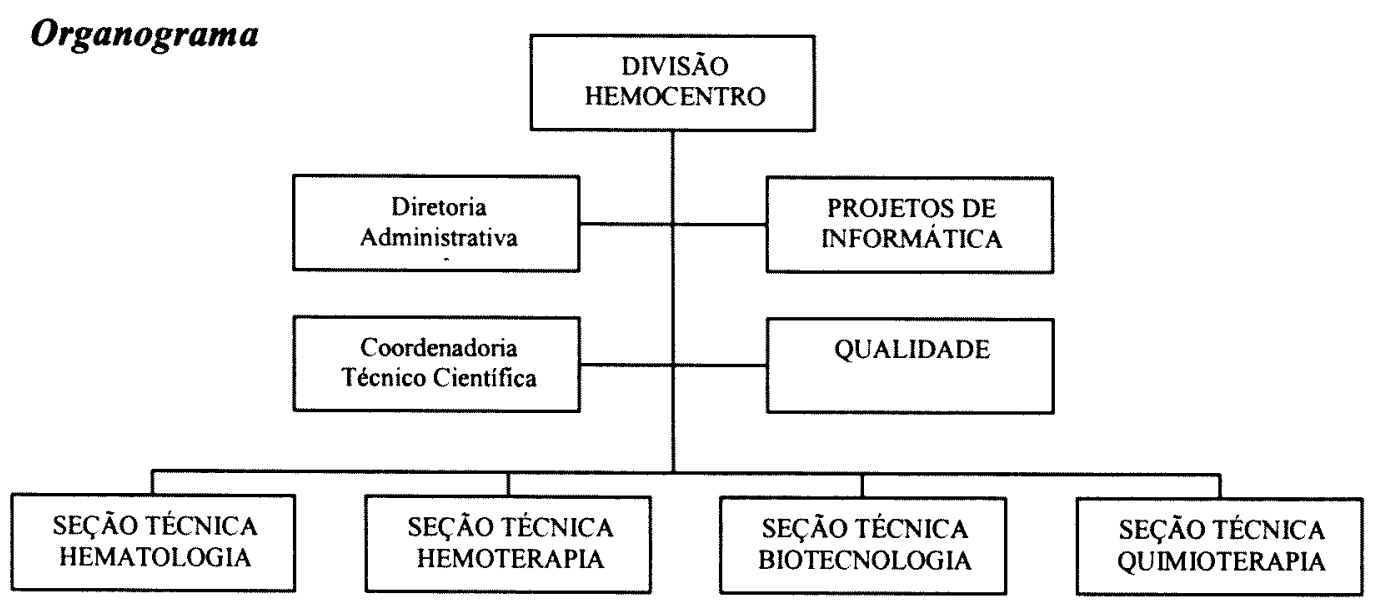


Em 1997, com o intuito provável de conter custos e com a argumentação natural de que estruturas horizontais seriam mais ágeis, através de estudo da Comissão de Estrutura Administrativa e Funções Autárquicas - CEAFA da UNESP, foram recortados níveis hierárquicos: diretorias de serviços e encarregaturas de setores, baixando-os de 5 para 3, como descrito por ANJOS ${ }^{48}$ em 1998.

Houve, também, congelamento do subquadro de funcionários, sem qualquer estudo prévio, juntando-se à não reposição de trabalhadores aposentados. Considerase provável a decorrência destes fatos à limitação orçamentária, no percentual de gastos com pessoal, determinada pela lei de responsabilidade fiscal em vigor.

A implicação imediata é o surgimento de coordenações informais nos diversos laboratórios do Hemocentro, muitas vezes não reconhecidas pelos trabalhadores e, absolutamente, não reconhecidas financeiramente, em substituição aos inexistentes encarregados de setor dos laboratórios diversos.

O grande número de trabalhadores graduados provoca outra distorção, pois ocupações técnicas de nível médio acabam sendo realizadas por profissionais de nível universitário, reforçando padrão de baixas recompensas financeiras pelo trabalho.

Aliando-se a estas questões, há grande responsabilidade do Hemocentro em suprir o Hospital das Clínicas de hemocomponentes, da melhor qualidade. É natural que as atividades e a convivência profissional naquela unidade sejam acompanhadas de ansiedade ou estresse, contribuem ao surgimento de distúrbios de comportamento para os quais, apenas uma abordagem psicológica terapêutica, deve ser insuficiente.

\subsection{O Ato da Doação de Sangue}

O sangue, segundo MONTEIRO ${ }^{31}$, é um bem natural, utilizado com finalidade terapêutica, que depende fundamentalmente da disponibilidade do doador. É propriedade intrínseca ao indivíduo, não se sujeitando ao princípio da função social ou da desapropriação. Sua cessão depende de ato livre e soberano de vontade e de consciência social, passível de influência do Estado, mas não de sua interferência.

SANTOS ${ }^{57}$ e colaboradores, descrevendo fase que denominaram politização do sangue, ocorrida na década de 1970, na Europa, citam R. M. Titmuss como sendo dos principais autores e críticos sobre a mercantilização do sangue e defesa pela doação altruísta, causando debate mundial sobre o tema e sobre a própria qualidade dos sistemas hemoterápicos. A repercussão nos Estados Unidos teve dimensão tamanha que influiu de maneira a que o governo federal adotasse política favorecedora à doação voluntária do sangue ${ }^{57}$. A instituição National Blood Policy interrompeu completamente o pagamento a doações de sangue total em 1.975. Todos os serviços de coleta de sangue mudaram para sistema de doações voluntárias não pagas ${ }^{52}$. Outro autor citado por SANTOS ${ }^{57}$, Kenneth J. Arrow, que apresenta argumentação desfavorável à de Titmuss, não acreditava que a criação de mercado para o sangue e para os hemoderivados pudesse reduzir o potencial de altruísmo existente em uma sociedade.

A Comunidade Européia exigia, através da diretiva 89/381, que seus Estados Membros tomassem "todas as medidas necessárias para promover a auto-suficiência em sangue e plasma humanos" e outras para "encorajar os doadores de sangue voluntários não pagos". Defesa sobre ética em favor das doações voluntárias não 
pagas de sangue foi exposta por KEOWN ${ }^{53}$, em 1997, utilizando-se de argumentos: doações pagas seriam desnecessárias, vista a experiência ilustrativa do Reino Unido que mantinha suprimentos adequados de sangue para alimentar a demanda clínica existente; altruísmo e solidariedade social: evidências sugeriam que o pagamento de alguns doadores desencorajaria a doação altruísta de outros e, citando Titmuss, salientou que "os caminhos os quais a sociedade se organiza e estrutura suas instituições sociais, em particular a saúde e bem estar, podem encorajar ou desencorajar o altruísmo no homem" promovendo a integração ou a alienação social; segurança: como os componentes celulares do sangue não podem ser inativados, com relação à presença de vírus, e os testes para detecção de infecção não serem completamente confiáveis, a segurança seria favorecida pelas doações não pagas; exploração: risco significativo de explorar os pobres e os em desvantagem social. A remuneração financeira agiria induzindo com mais força o pobre que o rico. O pobre, em geral, tem pior estado de saúde. O exemplo aos países subdesenvolvidos ou em desenvolvimento poderia conduzi-los a disseminada exploração de populações menos favorecidas. Comercialização do corpo humano: mesmo sendo produto renovável do corpo humano, o sangue seria como qualquer órgão, como rins, que não podem ser comercializados, inteiramente diferente de produtos ou dejetos como urina ou cabelos, também renováveis; o sangue teria inegável e simbólico significado para a comunidade e o significado social e moral da doação de sangue - a doação altruísta de uma vida ou de um presente de saúde que salva vidas, de uma pessoa para outra.

KEOWN ${ }^{53}$ conclui que, os cinco fatores apresentados, por si, não seriam suficientes na argumentação das doações não pagas; contudo, agrupados, constituiriam persuasivo motivo para a adoção dos princípios da doação não paga. Salienta que, no pagamento das doações, deveriam ser consideradas, além da remuneração monetária, também outras formas como horas livres de trabalho ou dispensa do trabalho, presentes, refeições e passagens, desde que não fossem essenciais e necessárias ao doador.

O não pagamento de doadores é um importante critério para evitar doadores de alto risco. Em vários países houve importantes esforços para promover sistemas de doadores voluntários não remunerados como França, Suíça, Finlândia, Holanda. Nos EUA, doações de sangue total não são pagas, mas pagamento pode ocorrer em aféreses de plasma. $\mathrm{Na}$ Alemanha e na Suécia, os doadores podem ter suas despesas pagas. Vários estudos em países desenvolvidos demonstram que sistemas de doadores de sangue não pagos diminuem consideravelmente os níveis de incidência de HIV (VAN DEN BURG ${ }^{30}$ ).

$\mathrm{Na}$ década de 1970 ficou claro, nos EUA, que o pagamento de doadores estava associado ao maior risco de transmissão de doenças. A epidemia da AIDS, em 1980 , forçou os serviços de sangue a solicitar que doadores pertencentes a grupos de risco deixassem de doar. Os critérios de exclusão para doadores ficaram cada vez mais rigorosos nas décadas de 1980 e 1990, enfocando a educação do doador, introduzindo questionários médicos com aprofundamento de questões pessoais para excluir doadores de alto risco ${ }^{30}$.

Sem dúvida, a doação de sangue, como bem escasso, estaria mais vulnerável e sujeita ao ambiente, a questões ideológicas, pressões políticas, informações noticiosas ou científicas com variedade de interpretações, necessitando de trabalho educativo e motivação da sociedade para manter-se sem retrair o fluxo do doador de sangue, sem retrair-se evitando conseqüências irrecuperáveis como a perda da vida 
humana. Nesta época, o perfil do doador, definido por pesquisa realizada pela Fundação HEMOPE, em Pernambuco, apontava para doadores do sexo masculino, semi-analfabetos, com renda mensal inferior a cinco salários mínimos, interessados no abono à falta ao trabalho, no lanche servido após a doação e na crença de que a doação de sangue faria bem à saúde (MONTEIRO ${ }^{31}$ ).

A Associação Brasileira de Doadores Voluntários de Sangue, fundada na década de 1960, organizada em moldes beneficentes, é a organização civil mais antiga no Brasil, propositadamente funcionando sem fundos monetários, procurando despertar formação altruística na população, através de campanhas educativas de doação voluntária que "despertam a felicidade, o prazer e a satisfação de, com um pouco de sangue, salvar a vida de alguém que nunca conhecerá - gesto mais nobre de que um homem é capaz" (SANTOS ${ }^{57}$ ).

Pessoas inaptas à doação de sangue, reveladas por sistema de informação mantido pela Cruz Vermelha Americana, denominado donor deferral registry $D D R$, em pesquisa amostral controlada realizada em Connecticut, New England e Southern regions, por MUNSTERMAN ${ }^{54}$ e colaboradores, nos meses de abril a julho de 1996, receberam questionários compostos por 24 questões, para resposta anônima, pelo correio.

O estudo confirma que créditos e recompensas podem influenciar de forma adversa na segurança dos suprimentos de sangue, incentivando indivíduos com maior risco, talvez desonestos com relação a seu comportamento ou estado de aptidão com a intenção de receber tais créditos e recompensas ${ }^{54}$.

O surgimento da AIDS, na década de 1980, transformou radicalmente o panorama da hemoterapia brasileira, segundo AMORIM FILHO ${ }^{3}$, acrescentando que o elevado número de casos de contaminação pelo vírus HIV por meio de transfusão mobilizou a opinião pública culminando com a proibição definitiva da doação remunerada - como exposto anteriormente - incluindo, ainda, que o sistema de doação remunerada deixou seqüelas: como o recrutamento de doadores era feito com estímulo de pagamento, a rede pública de hemocentros precisou se apoiar no chamado doador de reposição, amigo ou parente de paciente internado, com vários inconvenientes como a doação esporádica e vinculada à internação.

Em estudo descritivo realizado por ANJOS ${ }^{6}$, sobre doações de sangue, realizado no Hemocentro de Botucatu, no Estado de São Paulo, as doações de reposição foram predominantes no período de estudo, entre 1991 e 1998, com percentual médio de $67,6 \%$.

As doações de sangue são descritas ou conceituadas de várias maneiras: autólogas, por doadores convocados, de reposição ou vinculados, voluntários ou espontâneos, podendo ser novos ou de repetição.

O doador convocado é aquele, conhecido pelo serviço, em geral apresentando tipo sangüíneo sabidamente raro ou pouco comum, que se dispõe à doação de sangue, quando solicitado ${ }^{6}$.

A doação de reposição acontece pela solicitação a amigos e parentes de pacientes internados ou aguardando internação hospitalar. Este tipo de doação, segundo autores como LIMA ${ }^{12}$, envolve questões éticas, pois coage pessoas à doação de sangue, dizendo ser comum o pagamento de indivíduos para apresentação como doadores. 
A doação espontânea ou voluntária ocorre quando o individuo, de posse de informações, provindas de quaisquer fontes, sobre necessidades de sangue dos serviços, sente-se imbuído a doar sangue e o faz de maneira espontânea.

A doação autóloga acontece quando o doador de sangue realiza a doação para si próprio, antes de se submeter a ato cirúrgico, por exemplo.

THOMSON ${ }^{65}$ relata existirem vantagens óbvias em ampliar a retenção de doadores de sangue; contudo, por razões de segurança, alguns doadores, de fato, seriam mais desejáveis que outros. O doador "seguro" seria definido como aquele que proporcionaria doação sangüínea relatando ausência de comportamento de risco e todos os testes sorológicos não reagentes.

Doadores de reposição podem apresentar, com mais freqüência que doadores voluntários de sangue, testes laboratoriais reagentes para doenças infecciosas transmissíveis. Os programas de doações de reposição, por consequiência, apresentam maior prevalência proporcional de doadores com doenças transmissíveis; contudo, dois fatores contribuem para isso: muitos doadores novos (primeira doação) e pressão para doação que conduz a grande quantidade de atividades e comportamentos não revelados, incompatíveis com a doação de sangue (LIU ${ }^{61}$ ).

Para ampliar o número de doadores, LIU ${ }^{61} \mathrm{e}$ colaboradores procuraram identificar subgrupo de doadores de reposição, seguro, aceitável para doações de rotina, o que foi realizado através de estudo de coorte retrospectivo no National University Hospital, em Singapura, entre 1991 e 1995, quando os doadores foram classificados em 4 categorias: novo voluntário, voluntário de repetição, novo de reposição e reposição de repetição. No período, 18.606 doadores realizaram 23.082 doações em programa de reposição estruturado em doações pós transfusionais, segundo o autor, não coercitivo e sem imposição. Os resultados obtidos foram de que não há diferenças estatísticas significativas entre o doador novo voluntário e o de reposição de repetição, em termos de incidência de doenças infecciosas transmissíveis. Há risco maior entre os novos de reposição e o menor nos voluntários de repetição, mais recentemente denominados de fidelizados.

Doadores voluntários e de repetição, em geral, são considerados mais seguros quanto aos riscos de transmissão de doenças infecciosas pelo sangue. Com a intenção de confirmar esta expectativa SCHREIBER ${ }^{64}$ e colaboradores verificaram a incidência de infecções virais (HIV, HTLV, HCV e HBV) entre 868.403 doadores de repetição que, entre 1991 e 1993 realizaram, no mínimo, duas doações de sangue. O estudo foi feito por serviços de sangue de São Francisco e na Califórnia. Os resultados apresentados não demonstram diferenças entre a incidência de infecções por HIV, HCV e HBV e o número crescente de doações de sangue total; contudo, para o vírus HTLV as infecções decresceram com o incremento do número de doações por doador. Os achados não evidenciam risco menor de infecções virais transmissíveis por transfusão, não sendo aconselhável, segundo o autor, abreviação das triagens clínicas em doadores de repetição.

O tipo de doação que se procura, pela definição de sistema adotado pelo Brasil, é o da doação voluntária espontânea, quando impede que ocorra comercialização do sangue. Contudo, mais de que uma questão de comercialização envolvendo ética sobre mercantilização de partes do corpo humano, envolve problema de cultura cívica, presente nos diferentes países, com implicações diretas sobre os resultados das políticas de sangue. Em um país como o Brasil, em que a população não tem o sentido da doação como obrigação para com seu semelhante, 
em necessidade, calcar toda a política de sangue na doação voluntária poderia significar séria ameaça de paralisação do sistema hemoterápico, segundo nos relata COELHO $^{50}$.

Há necessidade de se discutir, com maior propriedade e profundidade, conceitos e definições sobre os tipos ou formas de doações de sangue descritas, principalmente considerando-se que, em princípio $e$ por estabelecimento constitucional ${ }^{24}$, todas as doações seriam voluntárias.

É fato que pessoas doam espontaneamente seu tempo e seu sangue quando há uma necessidade clara que conseguem compreender; dificil será compreender a necessidade diária de doações para manter o suprimento necessário nos diversos serviços e hospitais (WESTPHAL ${ }^{51}$ ).

Esforços importantes têm sido despendidos no entendimento da motivação individual para doação de sangue, mas os mecanismos de decisão que envolvem a doação voluntária continuam insuficientemente entendidos ${ }^{65}$.

A determinação do comportamento, de suas motivações e implicações no gerenciamento e aplicação das diversas formas de captação de doadores de sangue tem sido objeto de pesquisas. Os estudos envolvem grande variedade de aspectos, ciências e disciplinas como a epidemiologia, a história, a sociologia, a cultura, o momento político, entre outros fatores, adequadamente prescindindo de meta-análise que, segundo JÉNICEK ${ }^{66}$, seria a "integração de resultados de estudos independentes vinculados a uma mesma questão".

Em 1977, importante artigo de revisão de literatura sobre motivação e recrutamento de doadores foi realizado e publicado por OSWALT ${ }^{67}$. Relata que, havia 20 anos, os pesquisadores vinham apresentando resultados semelhantes. Descreve altruísmo e humanitarismo, reconhecimento pessoal e familiar, pressão social, reposição e recompensas como principais fatores de motivação para a doação de sangue. Para não doar, descreve medo, sangramentos, fraqueza, medo de furar o dedo, também: razões médicas, reações adversas, indiferença e inconveniência. Análises mais aprofundadas sobre motivação sugeririam que os doadores desejariam, ainda que inconscientemente, um "tapinha nas costas" pelo esforço realizado. Também ressalta a maior importância em buscar retenção e gerenciamento de doadores de repetição sobre as necessidades de sangue que motivar novos doadores.

Lembra que o reconhecimento imediato pela equipe de coleta em contato com o doador sobre a importância do ato realizado seria o principal reforço de atitude, amplamente comprovado por estudos de psicologia da aprendizagem. As melhores respostas, em termos de altruísmo, são obtidas quando o doador está em situação que lhe traga sensação de estar sendo necessário ${ }^{67}$.

No tópico relacionado à pressão social, OSWALT ${ }^{67}$ discorre sobre a relação entre modelos de pais ou amigos doadores com motivação para novos doadores.

A motivação decorrente de campanhas publicitárias no rádio, na televisão, nos jornais, relativamente inefetivas na captação de doadores considerando-se a importância ou ênfase que habitualmente se depositam em tais campanhas, é pequena, mas ressalta a importância em se desfazer informações errôneas ou duvidosas ${ }^{67}$.

Com o intuito de trazer à luz circunstâncias em que doadores novos passariam a doadores de repetição, considerando que estes proporcionariam maior segurança às transfusões e, ainda, para explorar sobre estratégias de exclusão de doadores de alto risco, PILIAVIN ${ }^{52}$, em 1990, publica nova e importante revisão sobre o assunto. 
$\mathrm{O}$ autor ${ }^{52}$ destaca, como fator de maior importância, com relação à distribuição de doadores de sangue por sexo que, nas mulheres, a depleção de seus estoques de ferro faria com que fossem rejeitadas para a doação de sangue o que retiraria ânimo para novas doações, sugere que o estímulo à doação feminina deva ser mantido através do oferecimento de possibilidades outras como de realizar doações de plaquetas por aférese.

Características como estado marital, idade, ocupação, educação e raça, como aspectos demográficos, teriam pouca importância em termos de motivação para doação. PILIAVIN ${ }^{52}$ salienta como fator causal, em alguns estudos, a história pregressa do doador. Descreve fatores da personalidade dos doadores, motivação, diferenças entre primeira doação e doações de repetição, motivações como altruísmo em contraposição a recompensas, considerações teóricas sobre motivação do doador e captação, terminando sua exposição falando sobre os sistemas de auto-exclusão.

FERNANDEZ-MONTOYA ${ }^{55}$, estudando a evolução de algumas atitudes, crenças e motivações nos doadores da Espanha, cita a "Teoria da Ação Racional" de Fishbein e Ajzen que diz que a maioria dos comportamentos social está sob controle voluntário, determinado pela intenção do indivíduo e que, esta, antecede o comportamento. $\dot{E}$ influenciada pelas atitudes em direção ao ato. A teoria foi revisada, indicando a possibilidade de os indivíduos não possuírem total controle sobre o comportamento ou de o comportamento não ser totalmente de sua decisão, a "Teoria do Comportamento Planejado".

A intenção se relaciona bem com o comportamento, o que sugere que o comportamento dos doadores de sangue deve estar sob controle da vontade ${ }^{55}$.

A teoria de persuasão de Fishbein e Ajzen foi citada e aplicada por LIMA \& d'AMORIM ${ }^{56}$, como alternativa no recrutamento de doadores voluntários e periódicos de sangue em população de estudantes universitários de Brasilia - DF, em estudo caso-controle, de 1985, utilizando comunicação persuasiva baseada em dados empíricos retirados de estudo prévio para estabelecimento preciso do comportamento a ser modificado relacionado a crenças comportamentais primárias, influência nas atitudes e intenções avaliadas com relação ao comportamento desejado. Foram efetuadas medidas de força das crenças (salvar vidas, tornar-se satisfeito, ser valorizado, suprir necessidades de sangue, etc.), medidas de atitude e de intenção, obtendo diferenças significativas entre os grupos, concluindo pelo êxito desse tipo de comunicação.

FERNANDEZ-MONTOYA ${ }^{55}$ aplicou questionário para estudo de coorte em amostra de 126 doadores de sangue, em período de 7 anos, entre 1987 e 1994, observando que houve mudanças em grande número de questões, relacionadas às crenças e atitudes, com redução do medo da doação e das necessidades de retorno e reconhecimento com incremento nas necessidades de conforto durante a doação e nas atitudes de amizade e solidariedade. As motivações não mudaram em $65 \%$ dos doadores da amostra.

Os fatores que influenciaram a transição da primeira doação para a segunda e da segunda para a terceira foram diferentes. A maioria dos doadores começou a se considerar como doadores regulares a partir da quarta doação ${ }^{55}$.

O conforto durante a doação é, possivelmente, fator importante e que cresce, em termos de expectativa, entre os doadoresde sangue ${ }^{55}$.

A primeira motivação que move o doador a doar sangue mostrou ser altamente valorizada pelo doador, responde a suas expectativas e crenças e deve estar 
profundamente enraizada no indivíduo. Onde a primeira motivação mudou, evoluiu para solidariedade e dever. A evolução para atitudes mais altruístas, em geral é acompanhada de menor necessidade de motivação externa ${ }^{55}$.

Em estudo com o propósito de identificar fatores mais importantes que afetam doadores "seguros" para nova doação, THOMSON ${ }^{65}$ e colaboradores enviaram questionários a 50.162 doadores que realizaram doações em serviços de sangue nos estados americanos da Califórnia, Michigan, São Francisco e Oklahoma, em 1993. Obteve respostas em $69 \%$ dos questionários enviados. Apenas 3,4\% dos doadores responderam apresentar baixa probabilidade de doar novamente, com maiores proporções da resposta entre doadores novos ( $1^{\mathrm{a}}$ doação), doadores de grupos de minorias e doadores com menor nível de escolaridade. Em seus resultados observou, ainda, entre os doadores considerados "seguros", que 6,3\% consideraram regular ou ruins seu estado de bem-estar durante a doação e $13,8 \%$ tiveram os mesmos conceitos com relação ao tempo de espera.

A influência de familiares, colegas de trabalho ou mesmo de patrões para a doação de sangue foi resposta de 7,4 a $11,3 \%$ das respostas dos questionários, enquanto que a mídia teve percentual de $2,1 \%$, doadores sem estímulo aparente $2,3 \%$ e apenas $1,8 \%$ relataram influência para doação procedente de iniciativas ou contatos dos próprios serviços de sangue ${ }^{65}$.

Uma das limitações do estudo, citada pelo autor ${ }^{65}$, foi a perda ou "resposta relativamente pobre" dos doadores novos ( $1^{\mathrm{a}}$ doação), que poderia não ser representativa, interferindo em termos dos resultados da aplicação do questionário.

Descreveu que os doadores considerados "seguros" teriam intenção de doar novamente em intervalo de até 12 meses. Neste aspecto os resultados sobre comportamento, descritos por ANJOS ${ }^{6}$, no Hemocentro de Botucatu esboçam semelhanças quando relata que as "doações de repetição ocorreriam de um ano a outro".

A metodologia que se utiliza de questionários, enviados pelo correio e que garantem o anonimato de quem responde, em pesquisas relacionadas a doadores de sangue, foi aplicada por autores como MUNSTERMAN ${ }^{54}$, WILLIAMS ${ }^{58} \mathrm{e}$ THOMSON ${ }^{65}$.

O controle dos doadores de sangue é a primeira etapa do processo hemoterápico para se obter sangue de boa qualidade (SANTOS ${ }^{18}$ ).

Nos EUA, guias sensiveis para doadores são considerados importantes para a segurança de doador e receptor, mas devendo ter suas questões bem administradas, para tratar melhor os doadores, com menos rigor tanto quanto o necessário ao não comprometimento de uma segurança verdadeira do produto a ser transfundido. Doadores voluntários de sangue não deveriam ser considerados como fazendo parte da indústria farmacêutica, nem a sala do doador, como linha de produção de fábrica (WESTPHAL ${ }^{51}$ ).

A exclusão de doadores de alto risco através de seleção é um dos passos cruciais para manter provimento adequado e seguro dos estoques de sangue. A doadores de alto risco correspondem altas incidências de infecções virais agudas, transmissíveis por transfusão de produtos do sangue. Testes em períodos de janela imunológica destas infecções agudas não são capazes de detectar agentes infecciosos. Assim, a maior importância da seleção dos doadores está em prevenir riscos de infecção nos períodos de janela imunológica (VAN DEN BURG ${ }^{30}$ ). 
A história clínica para deteç̧ão de comportamentos e fatores de risco, estabelecida para reduzir a transmissão de hepatite, teve impulso revigorado em 1983, nos EUA, pelo reconhecimento da transmissão da AIDS pelo ato transfusional. Com os avanços no conhecimento da AIDS os critérios de exclusão por comportamento foram sendo alterados, expandidos e redefinidos várias vezes naquele país (WILLIAMS ${ }^{58}$ ).

No início da epidemia de AIDS reconheceu-se que a educação de doadores tem importante significado na exclusão de doadores com maior risco de apresentarem infecção pelo HIV, em janela imunológica; porém, muito poucos estudos são adequados para demonstrar a eficácia dessas medidas educacionais ${ }^{30}$.

Os materiais educativos, desenhos de questionários e procedimentos de seleção utilizados pelos serviços de sangue devem ser validados com o uso de métodos cientificamente aceitos de avaliação para os doadores potenciais de todos os estratos da população ${ }^{58}$.

As ciências do comportamento que incrementam os elementos do processo de triagem são necessárias para melhor entendimento das motivações dos doadores soropositivos e os benefícios das questões orais diretas ${ }^{58}$.

Mesmo os materiais sendo compreensíveis, o ambiente que envolve o local de triagem clínica do doador deve ser conduzido por cuidadosos estudos dos materiais educativos e verdadeira avaliação pessoal do doador sobre sua aptidão para a doação 58

As limitações inerentes aos testes laboratoriais disponíveis e as possíveis consequiências ao receptor, se não forem providas informações acuradas, devem ser claramente apreciadas pelo doador ${ }^{58}$.

A educação dos doadores de sangue e os materiais e instrumentos de triagem devem ser refinados para refletir no reconhecimento do doador de que a infecção pelo HIV e outras infecções provindas de doações nos períodos de janela imunológica estão relacionadas a comportamentos de risco recentes, senão dos tradicionais fatores de risco ocorridos em passado remoto ${ }^{58}$.

Não há método preciso para quantificar o comportamento de retorno de doadores de sangue nos programas determinados a modificar comportamentos. Estudos quantitativos basearam-se em doações realizadas em períodos específicos de tempo, não medindo adequadamente o impacto dos esforços administrativos devendo os pesquisadores empenhar-se em descrição precisa de medidas de retorno de doadores de sangue, com base na investigação do altruísmo e de outras construções da psicologia social (JAMES \& MATTHEWS ${ }^{59}$ ).

Diante das necessidades de descrição quantitativa precisa para a construção de métodos estatísticos confiáveis, JAMES e MATTHEWS ${ }^{59}$ elaboraram paradigma do ciclo das doações, descrevendo quatro eventos essenciais:

a) $1^{\text {a }}$ doação (inicial);

b) Período obrigatório de inaptidão - deferral period (imediato à doação - cerca de 8 semanas);

c) Intervalo Eletivo;

d) Nova Doação,

com a finalidade de estudar características associadas: sexo, idade, grupo sangüíneo, entre outras, relacionadas aos intervalos determinados, possibilitando a elaboração de 
estratégias específicas para os diversos grupos de doadores. Para tanto, combinou com recursos estatísticos como curvas de sobrevivência (Kaplan - Meier), função de risco X função de sobrevivência (Mattheus and Farewell) e o modelo de risco proporcional (Cox), objetivando dois benefícios desta combinação:

1.) medidas eficientes do modo ou modelo de doação.

2.) Modelos apropriados e bem desenhados de intervenção para mudança de comportamento dos doadores onde os pesquisadores podem alcançar os méritos das estratégias propostas e administrar os suprimentos de sangue.

O ciclo das doações foi abordado por JAMES \& MATTHEWS ${ }^{60} \mathrm{em}$ outro estudo, em amostra de doadores do Gulf Coast Regional Blood Centre, em Houston, Texas, quando foram observados os primeiros cinco ciclos de doação, iniciados em 1987. Concluíram que estudos quantitativos são necessários para compreender o comportamento de retorno dos doadores e que o ciclo das doações, associado a análises de sobrevivência, é chave para obtenção de medidas, características confiáveis sobre o comportamento dos doadores e avaliação da efetividade das estratégias para sua captação.

ANJOS ${ }^{6}$, em estudo das doações de sangue no Hemocentro de Botucatu, descreveu perfil do doador de sangue como do sexo masculino, adulto jovem, com baixo nível de escolaridade, trabalhador braçal, casado e procedente do próprio município de Botucatu.

Observou aumento nos números absolutos das doações de sangue realizadas no período entre 1992 e 1998 referindo que os maiores aumentos proporcionais ocorreram entre os doadores do sexo feminino, doadores com idades entre 40 e 60 anos e nos doadores identificados como divorciados apontando para mudanças graduais no perfil do doador de sangue naquele serviço.

Entre os tipos de doação, descreveu as doações de reposição ocupando ainda posição destacada e maior aumento proporcional, contra os doadores voluntários ou espontâneos e fidelizados, mas indicou ocorrência processo gradual de fidelização pelo fato de quase a metade das doações de sangue terem sido realizadas por doadores com uma ou mais doações anteriores, em curva ascendente. Os doadores repetiriam doações, com mais freqüência, em intervalos que ultrapassariam de um ano a outro.

O fato de o percentual médio de $67,6 \%$ das doações partirem de doadores de reposição afirma o modelo de captação predominante, mas não explicita se haverá inversão de valores com aumento das doações voluntárias ou espontâneas, já que é difícil prever o impacto da maioria das campanhas realizadas com crianças e adolescentes desde 1995 . O autor ${ }^{6}$ considera que o reflexo poderia ser verificado ao menos nos cinco anos subseqüentes.

Existindo estudos que demonstram haver necessidades diferentes entre doadores, conforme o número de doações anteriormente realizadas, que os doadores em primeira doação buscariam segurança enquanto doadores com múltiplas doações buscariam conforto, ANJOS ${ }^{6}$ aponta a necessidade de abordagem diferenciada para os diversos tipos de doador na busca de sua fidelização, com procedimentos descritos em manual operacional.

$\mathrm{O}$ estudo conclui que as doações feitas por doadores voluntários ou espontâneos são de menor risco em relação aos doadores de reposição. O número de 
doadores convocados vem aumentando; mas, proporcionalmente, mantêm-se em patamar baixo e estável em relação aos outros tipos de doação e não indicariam ser este o tipo de doador em que se deveria investir, mesmo sendo de menor risco com relação ao doador voluntário ${ }^{6}$.

Sobre triagem clínica e triagem sorológica, ANJOS ${ }^{6}$ considerou alto o número de rejeições clínicas, sem garantias de diminuição do número de rejeições sorológicas, por parte dos Internos do $5^{\circ}$ ano médico, questionando a realização de triagens clínicas por estes alunos. $\mathrm{O}$ resultado deste questionamento foi a suspensão destas triagens clínicas, realizadas por Internos, no ano de 2001. A discussão sobre a realização das triagens clínicas por enfermeiros e médicos e sobre seu perfil desejado mereceria ser realizada. Sugeriu que as triagens clínicas pudessem ser monitoradas individualmente, correlacionando-as com as rejeições sorológicas assim como apontou a necessidade de melhoria do sistema de captação de doadores para diminuição dos efeitos de omissão ou de inverdades ditas durante o processo de triagem clínica pelo candidato à doação de sangue.

Os principais motivos de rejeições clínicas apresentados pelo estudo ${ }^{6}$ foram hipertensão arterial, uso de álcool, uso de medicamentos, gripes e anemias, poderiam ser correlacionados com faixas etárias, sexo e procedência, com o intuito de auxiliar na melhoria do processo captação. Os motivos, causas de inaptidão clínica, poderiam orientar ainda a abordagem dos doadores ou candidatos à doação de sangue para que tivessem sua saúde preservada e motivá-los à futuras doações de sangue. Sugeriu que orientação e motivação poderiam ser realizadas, de maneira sistemática, nas salas de espera dos candidatos à doação através de vídeos, folhetos instrutivos ou mesmo por atividades semelhantes às de grupos terapêuticos e, necessariamente, passarem a fazer parte dos discursos de captação, de maneira semelhante ao que ocorria com relação às doenças infecciosas.

A captação de doadores de reposição para garantia de suprimento adequado de sangue ao Hospital de Clínicas e aos serviços de sangue da região, trabalho fundamental da Seção Social Médica, sem vínculo direto ou subordinação à Divisão Hemocentro constituiria possibilidade importante de conflitos ${ }^{6}$.

As coletas externas precisariam ser planejadas de forma a melhorar a qualidade dos hemocomponentes produzidos, deixando, progressivamente, de funcionar como forma básica de divulgação das necessidades de sangue. ANJOS ${ }^{6}$ sugeria que fossem substituídas, talvez, por programas baseados em captadores voluntários, nos municípios com sistema de validação sobre a maneira de transporte do material coletado durante as coletas externas, ao menos em relação à temperatura de conservação desse material. Os dados de cadastro, durante as coletas externas, poderiam ser confrontados, pelo sistema de "bloqueio de cadastro", se houvesse a possibilidade de estas informações estarem contidas em computador portátil (note book) que pudesse ser transportado aos locais de coleta. Porém, enquanto isso não ocorre, esses procedimentos deveriam permanecer, sob a realização, de forma manual, das fichas de cadastro, como está previsto nas normas do Hemocentro. $\mathrm{O}$ sistema de "bloqueio de cadastro" poderia se estender a toda Hemo-rede, no Estado de São Paulo, de maneira a fornecer informações sobre possiveis doações anteriores, em pontos diferentes do Estado e condição de aptidão do doador de sangue.

As campanhas realizadas, intensificadas nos últimos anos, certamente tiveram a influência positiva sobre a população, haja visto o aumento no número de doações. Campanhas para captação de doadores, além de programadas, devem ser ordenadas e 
monitoradas para comprovação ou não de sua eficácia, também, a relação com seu custo.

ANJOS ${ }^{6}$ considera que questões relacionadas à organização, à administração e aos recursos financeiros disponíveis da Divisão Hemocentro seriam de fundamental importância no comportamento das doações de sangue.

$\mathrm{O}$ aspecto de informalidade, presente no cotidiano do trabalho e como característica da cultura organizacional da instituição, teria lado positivo, o de facilitar relacionamentos interpessoais. Outro desafio era de aproveitá-lo ao máximo como facilitador ao funcionamento da instituição, dentro da estrutura formal existente.

Vários dados de produção ou de características dos doadores de sangue estão disponíveis para análise. Contudo, alguns têm maior importância e deveriam ser monitorados de forma breve, para que medidas de contingência pudessem ser tomadas rapidamente, relacionadas ao número de doações e tipo de doador, rejeições clínicas e sorológicas e profissional que realiza a triagem. Outras características devem ser monitoradas, mas devem estar vinculadas a programações ou atividades planejadas.

O Hemocentro de Botucatu, pela forma como vinha sendo dirigido, mesmo sem compartilhar, de maneira explicita, objetivos bem delimitados, avançava e se desenvolvia rapidamente dentro do Hospital de Clínicas da Faculdade de Medicina, em termos de organização. Teria papel fundamental como agente de mudanças, na época, mesmo com a apresentação de possíveis conflitos internos. Provavelmente, teria maiores possibilidades de superá-los e influenciar outras áreas técnicas e administrativas institucionais.

As necessidades internas do Hemocentro e do Hospital de Clínicas precisam ser satisfeitas, mas sua clientela externa precisa ser considerada e influenciada, da mesma forma, no cumprimento de seu papel técnico de assistência aos serviços de sangue da região. Este papel não se resume a treinamentos. Complementa-se em supervisões e orientações técnicas locais. Deste modo, promove, aproxima, incentiva e contagia os diversos serviços de sangue e os municípios aos quais pertencem, para que alcancem a autonomia relacionada ao número de doadores necessários ao seu próprio suprimento de sangue, com qualidade.

Falhas na captação de doadores, por diversos fatores, prejudicam o funcionamento dos serviços de saúde dependentes de sangue ou hemocomponentes, obrigam a suspensão de cirurgias eletivas, a gastos desnecessários com transporte na busca de hemocomponentes de outros serviços, a atendimento inadequado de pacientes nos serviços de urgência e emergência, entre outros problemas de atendimento; mas, certamente, a perda de vidas pela falta de captação adequada de doadores é a final e pior conseqüência e que deveria, com todos os esforços possíveis, ser evitada. 


\subsection{Trabalhadores: Aprendizado e Vínculo}

A ampliação do número de doadores de sangue assegurando retorno para novas doações com a utilização de técnicas ou padrões de garantia de qualidade do sangue coletado, tarefa de execução complexa, depende, fundamentalmente, da disposição e envolvimento das equipes de captação e coleta do sangue com o doador.

A autonomia do profissional diretamente envolvido para a tarefa e o gerenciamento da equipe de forma a não tolher iniciativas ou possibilitar sobreposição de interesses corporativos em combinação com grau de responsabilidade dos trabalhadores é dos principais segredos, segundo CAMPOS ${ }^{70}$, para assegurar qualidade, pressupondo capacidade de assumir responsabilidades sobre problemas de outros.

No outro lado, a alienação e o descontentamento dos profissionais destas áreas pode resultar em degradação de resultados, com qualidade duvidosa dos produtos finais do sangue e com perda de doadores. A alienação, em parte, estaria relacionada, segundo o autor, a organização parcelar do trabalho: o profissional não se sentiria sujeito ativo nos processos e programas, não se responsabilizaria pelo projeto final de intervenção em que participa, perdendo o contato com elementos potencialmente estimuladores da sua criatividade. A alienação do profissional, para CAMPOS $^{70}$, aconteceria como processo de estabelecimento de estereótipos fixos no qual se perderia a possibilidade de distinguir a singularidade de cada caso, processo consolidado pelo jogo institucional. No caso, o fluxo do doador, pelos atendimentos sucessivos a que se submete na recepção, com o técnico de microhematócrito, pelo triador clínico, na identificação de bolsas e coleta de sangue, no lanche.

A padronização de técnicas mais evidentes e bem estabelecidas, principalmente nas áreas de triagem clínica e de procedimentos de coleta, não garante execução coerente das atividades, como observado por ALVARADO ${ }^{81}$.

Ainda para CAMPOS ${ }^{70}$, a relação entre autonomia e responsabilidade passaria por, ao menos, três critérios, o de validação de arranjo institucional assegurando objetivos da programação estabelecida, de viabilidade técnica, financeira e politica dos arranjos acordados e da realização profissional e financeira do trabalhador.

A aproximação do profissional dos resultados de seu trabalho dependeria da restauração da liberdade criadora e da ampliação de suas responsabilidades o que poderia ser dado, na prática, pelo Vínculo, no caso dos profissionais em referência, pelo Vínculo com o doador de sangue.

Vínculo significa refletir sobre a responsabilidade e o compromisso que a equipe tem sobre o doente, sobre o doador de sangue. Criar Vínculos "implica em ter relações tão próximas e tão claras, que nós nos sensibilizamos com todo o sofrimento daquele outro, daquela população", no caso o doador de sangue e, talvez não de uma forma direta, o doente, o acidentado que necessita da transfusão. "É permitir a constituição de um processo de transferência" entre o doador e o trabalhador, "que possa servir à construção da própria autonomia" do doador de sangue (MERHY ${ }^{84}$ ).

CAMPOS ${ }^{70}$ fala sobre a subjetividade no relacionamento entre médicos e pacientes que, quando se apaga, "afoga qualquer vestígio de solidariedade, durante sua convivência obrigatória, estando condenados terapeutas e enfermos". Ressalta que, na saúde pública, a esterilização dessas relações acontece com maior facilidade ao considerar o objeto de trabalho como sendo a "população" ou uma "coletividade". 
Doadores de sangue são tipo especial de clientela já que não são doentes ou enfermos, em princípio, além de dispor de produtos do seu próprio corpo, voluntariamente. Contudo, tendência ao tratamento pelos profissionais, como se estivessem naquela condição, é comum, muito provavelmente pela proximidade dos serviços de sangue com o hospital e com as atividades hospitalares.

É comum nas organizações que se exijam qualidades humanas mínimas para o trabalho, que as pessoas sejam tratadas como insumos, como recursos disponibilizados para serem usados. Exatamente esta orientação que, na opinião de SENGE ${ }^{73}$ funciona como obstáculo ao desenvolvimento de lideranças e do pensamento sistêmico, como forma de incrementar o pensamento reducionista tradicional: substituição das habilidades humanas mínimas por habilidades pessoais $\mathrm{e}$ interpessoais.

As habilidades de aprendizagem individuais e coletivas, alimentando a visão pessoal para construir genuinamente visões gerenciais compartilhadas seria maneira de evitar o fato de que, a maioria das intervenções gerenciais, piora as coisas ao invés de melhorá-las ${ }^{73}$.

O diálogo, como fluxo de significado, possibilitaria ou facilitaria novas formas de pensar e interagir, estabelecendo visões e compreensões compartilhadas e novas capacidades de ações coordenadas. As mudanças organizacionais de estrutura dependem de mudanças estruturais internas, com alterações no que chama de modelos mentais, o que ocorreria em comunidades de aprendizagem. $\mathrm{O}$ alcance destas mudanças exigiria esforços sustentados na prática das disciplinas ${ }^{73}$.

Os Modelos Mentais, como disciplina de aprendizagem, é disciplina de habilidades de reflexão e indagação, que se concentra em desenvolver consciência das atitudes e percepções que influenciam o pensamento e as interações. Reflexão contínua sobre as imagens internas do mundo, reconsiderando-as e falando a respeito delas. Pode propiciar o alcance de maior capacidade de governar ações e decisões.

Uma forma de facilitar a identificação dos modelos mentais é relacionar as ações de curto prazo para reagir às crises, empreendidas no passado, talvez sem pensar nas conseqüências de longo prazo ${ }^{76}$.

\subsection{Pensamento Sistêmico}

As organizações são sistemas que apresentam conexões invisíveis de ações inter-relacionadas que podem, muitas vezes, levar anos para manifestar seus efeitos, umas sobre as outras. Com a participação na organização, fica mais difícil observar os padrões de mudanças, tem-se a tendência natural de se analisar partes isoladas do sistema, sem que se consiga identificar e resolver os problemas mais profundos. $\mathrm{O}$ pensamento sistêmico é referência conceitual, conjunto de conhecimentos e ferramentas para esclarecer padrões em um todo que ajudar a ver como modificá-los efetivamente ${ }^{73}$. O pensamento sistêmico resgata a percepção da dinâmica do todo $\mathrm{e}$ das interações de suas partes ${ }^{85}$. 


\subsection{Alavancagem}

A alavancagem é definida por SENGE ${ }^{73}$ como o principal resultado prático do pensamento sistêmico e consiste em se identificar de onde as ações e mudanças, nas estruturas organizacionais, podem levar a melhorias significativas e duradouras, às vezes pequenas, mas bem focalizadas, em geral evitando as soluções sintomáticas, que muitas vezes melhoram situações em curto prazo e que pioram no longo prazo. A alavancagem nem sempre é óbvia aos nossos olhos, porque, não raro, necessitam que se enxergue estruturas subjacentes às ações. Os arquétipos têm como finalidade facilitar a identificação dessas estruturas e, por conseqüência, encontrar pontos de alavancagem, especialmente em meio às pressões que permeiam a vida organizacional.

\subsection{Discurso do Sujeito Coletivo}

O Discurso do Sujeito Coletivo é uma proposta de organização e tabulação de dados qualitativos de natureza verbal, obtido de depoimentos, artigos de jornal, matérias de revistas semanais, cartas, papers de revistas especializadas, etc., consistindo em analisar material verbal coletado, extraindo-se Idéias Centrais ou Ancoragens semelhantes e compondo-se um ou vários discursos-síntese, na primeira pessoa do singular. Esse "eu", sintático, ao mesmo tempo em que sinaliza a presença de um sujeito individual do discurso, expressa uma referência coletiva, na medida em que esse "eu" fala em nome de uma coletividade ${ }^{75}$.

\subsection{Complexos, Arquétipos e Normoses}

SENGE ${ }^{73}$ utiliza termos e conceitos como Modelos Mentais, Arquétipo, expressões comumente usadas pela psicologia, para estruturar sua obra. A abordagem desses termos e conceitos auxilia na compreensão mais adequada interdisciplinar necessária a alcançar qualidade no trabalho relacionado ao sangue.

Carl Gustav Jung, em suas idéias filosóficas fundamentais de sua importante obra dentro da psicologia, define Complexos como agrupamentos de conteúdo psíquico carregados de afetividade, verdadeiras unidades vivas, capazes de existência autônoma e dos quais depende o mal-estar ou o bem-estar da vida do indivíduo. Não são, por essência, elementos patológicos, podendo significar a existência de algo conflitivo e inassimilado e, para serem assimilados, será necessário, junto a sua compreensão em termos intelectuais, que os afetos, nele condensados, exteriorizemse por meio de descargas emocionais. Complexos seriam a imagem de situações psíquicas fortemente carregadas de emoção e incompatíveis com a atitude e a atmosfera consciente habituais ${ }^{77}$.

A constatação de que existem tipos bem caracterizados e facilmente reconheciveis de Complexos sugere que estes repousem sobre bases igualmente típicas que seriam os Arquétipos, isto é, os alicerces da vida psíquica, comuns a todos os seres humanos. O Complexo mostraria conexões com os Arquétipos, ou seja, haveria sempre uma ligação entre as vivências individuais e as grandes experiências da humanidade ${ }^{77}$. 
Arquétipos são possibilidades herdadas para representar imagens similares, são formas instintivas de imaginar. São matrizes arcaicas onde configurações análogas ou semelhantes tomam forma. O Arquétipo funciona como um nódulo de concentração de energia psíquica. Quando essa energia, em estado potencial, se atualiza, toma forma, aí então teremos a imagem arquetípica. O Arquétipo seria unicamente uma virtualidade ${ }^{77}$.

Os Arquétipos resultariam do depósito das impressões superpostas deixadas por certas vivências fundamentais, comuns a todos os seres humanos, repetidas incontavelmente através de milênios.

Peter Senge afirma que "somos prisioneiros de estruturas que desconhecemos" e que, o aprendizado em enxergar as estruturas, dentro das quais se opera, inicia processo de libertação das forças, antes não identificadas, o que permite que se domine habilidades de trabalhar e mudar tais estruturas. Considera que uma das percepções mais importantes e potencialmente mais poderosas surgidas no campo do pensamento sistêmico é que determinados padrões de estrutura ocorrem repetidas vezes. "Esses "arquétipos de sistema" ou "estruturas genéricas" são o segredo para aprendermos a ver as estruturas em nossas vidas pessoais e organizacionais" 73 .

Descreve como sentenças básicas ou histórias simples contadas repetidas vezes, como temas comuns na literatura e falas recorrentes que se repetem com diferentes personagens e contextos e que um número relativamente pequeno de arquétipos seria comum em uma grande quantidade de situações gerenciais. Algumas destas estruturas genéricas são chamadas de normoses. Um dos conceitos de normose foi introduzido por WEIL ${ }^{90}$ que se apresenta como "um conjunto de normas, conceitos, valores, estereótipos, hábitos de pensar ou de agir, que são aprovados por consenso ou pela maioria de uma determinada sociedade e que provocam sofrimento, doença e morte. Em outras palavras, é algo patogênico e letal, executado sem que seus autores e atores tenham consciência de sua natureza patológica". LELOUP 90 acrescenta que "o consenso e a conformidade impedem o encaminhamento do desejo do nosso interior".

\subsection{Avaliação de serviços e programas sociais}

Um dos tipos de avaliação, descrito por AGUILAR e ANDER-EGG ${ }^{68}$, é a avaliação ex-ante, caracterizada por ser feita anteriormente à tomada de decisão de empreender programa ou projeto, realizando a estimação crítica de sua pertinência, viabilidade e eficácia potencial. Os autores chamam de pertinência do projeto com a realidade a coerência entre as soluções propostas e a realidade a ser modificada. A viabilidade e a coerência estão relacionadas à relação entre meios (recursos) e objetivos, entre objetivos e metas e entre diagnóstico e proposições. Destacam o aspecto econômico da rentabilidade econômica das diferentes ações para o alcance dos objetivos propostos.

COTTA ${ }^{69}$ descreve como aspecto-chave na elaboração de projetos de avaliação o traçado do perfil completo da intervenção, com exame dos objetivos, coleta de informações sobre seu mecanismo de implementação, o conhecimento da equipe responsável e grupos de potencialmente afetados pelo seu conteúdo. A autora cita a avaliação ex-ante como oferecendo subsídios ao processo decisório, apontando a conveniência ou não de se realizar o projeto. 


\section{JUSTIFICATIVA}

$\mathrm{O}$ objeto deste trabalho é o doador de sangue, questões relacionadas ao processo de captação com o intuito de aprofundamento e direcionamento, identificação e monitorização das suas diversas formas.

Aprofundar o conhecimento do perfil do doador de sangue, considerando aspectos socio-econômicos, culturais e de motivação é passo inicial para renovação do programa de captação de doadores de sangue do Hemocentro de Botucatu.

A renovação do programa de captação justifica-se, entre outros aspectos possíveis, além da perspectiva longínqua de surgimento de substitutos para o sangue, pelo aumento das demandas por hemocomponentes e hemoderivados decorrentes da:

a) incorporação tecnológica crescente do Hospital de Clínicas;

b) aumento da longevidade da população, com maior ocorrência de doenças crônicas;

c) aumento do número de transplantes (destacando a ampliação de transplantes renais e o início de transplantes hepáticos) e de traumas;

Melhoria constante da qualidade do sangue pela captação e retenção de doadores de menor risco seria outra justificativa para a renovação do programa.

$\mathrm{O}$ melhor direcionamento da captação de doadores de sangue, através do conhecimento daqueles mais saudáveis, implica em provável diminuição do risco de doações realizadas por doadores em período de "janela imunológica" caracterizando sangue de melhor qualidade, com beneficios evidentes aos futuros receptores.

Para o doador fidelizado, um dos alvos desta pesquisa, o contato com o serviço de sangue terá o intuito de estreitamento dos laços e incentivo a continuidade das doações: a pesquisa de seu perfil como forma de reconhecimento de sua importância no sistema.

Aos doadores de reposição com evento único de doação, a pesquisa de seu perfil histórico traz aspectos fundamentais:

d) possibilidade de comparação com perfil de doador de menor risco;

e) à comparação, possibilidade de redirecionar formas de captação;

f) motivações contrárias à continuidade das doações de sangue podem determinar falhas na captação inicial, falhas de tratamento oferecido aos doadores durante as atividades da coleta ou mesmo apontar falhas administrativas como incongruência de horários de funcionamento do serviço de sangue, incongruência no produto a ser doado (sangue total por aférese de plaquetas, por exemplo);

Com o aumento da captação de doadores de sangue de menor risco o resultado esperado seria de:

g) diminuição das rejeições clínicas;

h) diminuição das rejeições sorológicas;

i) diminuição do descarte de bolsas (sorologia reagente);

j) diminuição conseqüente dos custos do processo de coleta.

A motivação da equipe de captação e coleta de sangue, estabelecida através do Vínculo (CAMPOS ${ }^{70}$ ) com o doador, além dos benefícios esperados de melhoria da qualidade dos produtos do trabalho, pode gerar maior comprometimento $\mathrm{e}$ satisfação para o trabalhador.

Em termos de coletividade, a melhoria da qualidade do sangue diminuiria o risco da transmissão de doenças por via transfusional. 
A capacitação da população para realização de doações seguras e de menor risco transfusional é um estímulo ao auto-cuidado, estímulo propiciado em palestras e contatos individuais e, de maneira mais ampla, através dos meios de comunicação.

Atualmente, este trabalho sensibiliza cerca de 15.000 candidatos à doação, anualmente. 


\section{OBJETIVO}

\subsection{Objetivo geral}

Realizar avaliação de predecisão ou ex-ante sobre renovação do Programa de Captação de Doadores de Sangue do Hemocentro de Botucatu.

\subsection{Objetivos específicos}

- Estabelecer perfil do doador que proporcione menor risco de transmissão de doenças por transfusão;

- Estabelecer perfil de doadores de maior risco de transmissão de doenças por transfusão;

- Comparar os diversos perfis encontrados entre si e em função da literatura;

- Descrever procedimentos que potencialmente poderão ter seus custos diminuídos em função da captação dos doadores com perfil de menor risco de transmissão de doenças por transfusão de sangue;

- Descrever as diversas formas de captação de doadores de sangue existentes, formais e informais;

- Estabelecer o perfil do trabalhador de captação de doadores e de coleta de sangue do Hemocentro de Botucatu sob a ótica do Vínculo (CAMPOS ${ }^{70}$ ) com o doador de sangue e sob as disciplinas de aprendizado sugeridas por SENGE ${ }^{73}$ : pensamento sistêmico, domínio pessoal, modelos mentais, visão compartilhada e aprendizagem em equipe. 


\section{MATERIAL e MÉTODO}

\subsection{Estudo da população de doadores de sangue de menor risco}

Utilizando-se o banco de dados existentes no Hemocentro, obteve-se listagem de 92 doadores os quais realizaram ao menos seis doações no período de dois anos, entre julho de 2001 e junho de 2003. Destes, foram excluídos 9 doadores por participarem de programação de coleta específica de plaquetas ou de "mini-painel" para fenotipagem.

Encontrou-se número total de 83 doadores com características de menor risco, que tinham, como indicadores, a doação voluntária espontânea (ANJOS ${ }^{6}$ ), resultados de rastreamento sorológico não reagentes, procedência do município de Botucatu e o Hemocentro como local de coleta interna. Destes doadores, 38 compareceram e foram entrevistados $(45,8 \%)$, não se conseguiu contato com 24 doadores por incoerência de endereço ou telefone $(28,9 \%)$, sendo 21 doadores não compareceram ou não retornaram após contato inicial ou agendamento da entrevista. Os contatos e entrevistas aconteceram durante dois meses, entre dezembro de 2003 e janeiro de 2004.

Facilitou-se o acesso para a realização das entrevistas, marcadas no centro da cidade de Botucatu. Foram realizadas duas visitas domiciliares.

Todos os entrevistados receberam esclarecimentos e agradecimentos, concordaram com a entrevista e assinaram termo de consentimento. As entrevistas foram organizadas de maneira estruturada, apresentadas como questões fechadas (anexos). Constaram da entrevista questões epidemiológicas, demográficas, socioculturais e de comportamento para caracterização do doador com variáveis já referidas na literatura ou introduzidas por profissionais ligados à captação de doadores dentro do Hemocentro, destacando: sexo, idade (em anos), estado marital, ocupação (o que faz / posição na ocupação), educação (em anos de estudo), etnia, situação de emprego, número total de doações, habitação (número de cômodos), composição familiar (número de pessoas habitantes da mesma residência), participação em organizações (sindicatos, clubes, comunidades religiosas).

Aplicaram-se as seguintes questões abertas (TRIVIÑOS ${ }^{71}$ ) aos doadores:

a) "você já doou sangue várias vezes, não é? você lembra por que você resolveu doar a primeira vez? Fale um pouco sobre isso.";

b) "e as outras vezes? Você doou pelos mesmos motivos, ou não?";

c) "Nestas vezes que você doou, houve algum problema, alguma coisa que dificultou a doação, ou não?".

As questões abertas constantes das entrevistas foram gravadas e transcritas, depois foram agrupadas todas as respostas para uma mesma questão, identificadas as expressões chave, as idéias centrais e ancoragens, elaborados os discursos-sínteses e finalização do Discurso do Sujeito Coletivo (LEFEVRE ${ }^{75}$ ).

As idéias centrais semelhantes foram quantificadas e aparecem sob a notificação percentual como medida de força. Representam o percentual de referência de determinada idéia central com relação ao número total de entrevistados (F\%).

O Discurso do Sujeito Coletivo é apresentado, integralmente, nos anexos. 


\subsection{Estudo de população de doadores com evento único de doação de sangue}

No banco de dados do Hemocentro obteve-se listagem de 676 doadores, supostamente com evento único de doação de sangue, ocorrido no período de um ano entre julho de 2000 e junho de 2001, procedentes do município de Botucatu.

Foram entrevistados 26 doadores, entre janeiro e março de 2004, sendo que, para 19 doadores, as entrevistas foram realizadas em local central do município de Botucatu, como maneira de facilitar o acesso e, as outras 7 , no próprio domicílio, após convite realizado por telefone. Procurou-se marcar as entrevistas, de imediato, em horário que pudesse facilitar o deslocamento do doador.

Parte dos contatos iniciais e convites para as entrevistas foram efetuados por Assistente Social capacitada que realizou as marcações e encaminhamentos para as entrevistas.

Dos 153 doadores aptos e que se enquadravam, em princípio, às exigências para participar das entrevistas, $102(66,7 \%)$ foram localizados através de contatos indiretos (parentes ou pessoas que habitavam no mesmo domicílio) e não ofereceram resposta. Outros 25 doadores marcaram local, dia e horário para a entrevista e não compareceram (16,3\%).

À semelhança do grupo entrevistado descrito no item anterior, todos os 26 entrevistados deste grupo receberam esclarecimentos e agradecimentos, concordaram com a entrevista e assinaram termo de consentimento. As mesmas questões fechadas foram aplicadas neste grupo de doadores.

Aplicaram-se as seguintes questões abertas (TRIVIÑOS ${ }^{71}$ ) aos doadores:

a) "na sua ficha, eu vi que você doou sangue só uma vez, não é? por que você resolveu doar?";

b) "daí você não doou mais, não é? por que? Fale um pouco sobre isso.

As questões abertas constantes das entrevistas também foram gravadas e transcritas, depois foram agrupadas todas as respostas para uma mesma questão, identificadas as expressões chave, as idéias centrais e ancoragens, elaborados os discursos-sínteses e finalização do Discurso do Sujeito Coletivo (LEFEVRE ${ }^{75}$ ), da mesma forma como descrito no item anterior, inclusive com relação a quantificação das idéias centrais semelhantes, expressas também como medida de força (F\%).

O Discurso do Sujeito Coletivo é apresentado, integralmente, nos anexos.

\subsection{Otimização de custos}

Realizou-se o levantamento do número de bolsas de sangue total descartadas por rejeição sorológica entre os anos de 2001 e 2003, assim como o número de bolsas descartadas por prazo de validade vencido, e efetuados os cálculos de acordo com os valores demonstrados por ALVARADO ${ }^{81}$.

Também, levantou-se o número de rejeições clínicas a candidatos a doação de sangue, nos mesmos anos e, da mesma forma, foram executados os cálculos para obtenção dos valores dos custos do procedimento ${ }^{81}$.

Os dados encontrados foram apresentados de maneira a auxiliar a estabelecer metas relativas a otimização dos custos. 
A Tabela I ilustra as perdas mensais por validade:

Tabela I - Distribuição mensal de descartes de bolsas de concentrado de hemácias, por validade, do Hemocentro de Botucatu.

\begin{tabular}{cccccccccccccc}
\hline \hline & \multicolumn{10}{c}{ MÉS } \\
\cline { 2 - 14 } ANO & JAN & FEV & MAR & ABR & MAI & JUN & JUL & AGO & SET & OUT & NOV & DEZ \\
\hline 2001 & 240 & 14 & 46 & 34 & 72 & 42 & 119 & 167 & 199 & 203 & 78 & 14 \\
2002 & 68 & 58 & 116 & 75 & 119 & 131 & 24 & 112 & 80 & 56 & 28 & 88 \\
2003 & 242 & 34 & 45 & 56 & 54 & 59 & 111 & 97 & 63 & 206 & 214 & 56 \\
\hline
\end{tabular}

Fonte: sistema SBS - Hemocentro de Botucatu

A Tabela II, com respectivo Diagrama de Barras, ilustrativo, aponta para constância no consumo mensal de bolsas de concentrado de hemácias nos últimos anos.

Tabela II - Distribuição mensal de bolsas de concentrado de hemácias utilizadas ou distribuídas pelo Hemocentro de Botucatu.

\begin{tabular}{ccccccccccccc}
\hline \hline & \multicolumn{10}{c}{ MÉS } \\
\cline { 2 - 27 } & JAN & FEV & MAR & ABR & MAI & JUN & JUL & AGO & SET & OUT & NOV & DEZ \\
\hline 2001 & 793 & 708 & 800 & 731 & 773 & 767 & 705 & 697 & 737 & 738 & 674 & 637 \\
2002 & 685 & 723 & 772 & 746 & 778 & 862 & 754 & 745 & 791 & 870 & 693 & 676 \\
2003 & 731 & 907 & 734 & 795 & 775 & 888 & 875 & 774 & 881 & 690 & 923 & 880 \\
\hline
\end{tabular}

Diagrama de Barras - Distribuição mensal de bolsas de concentrado de hemácias utilizadas ou distribuidas pelo Hemocentro de Botucatu.

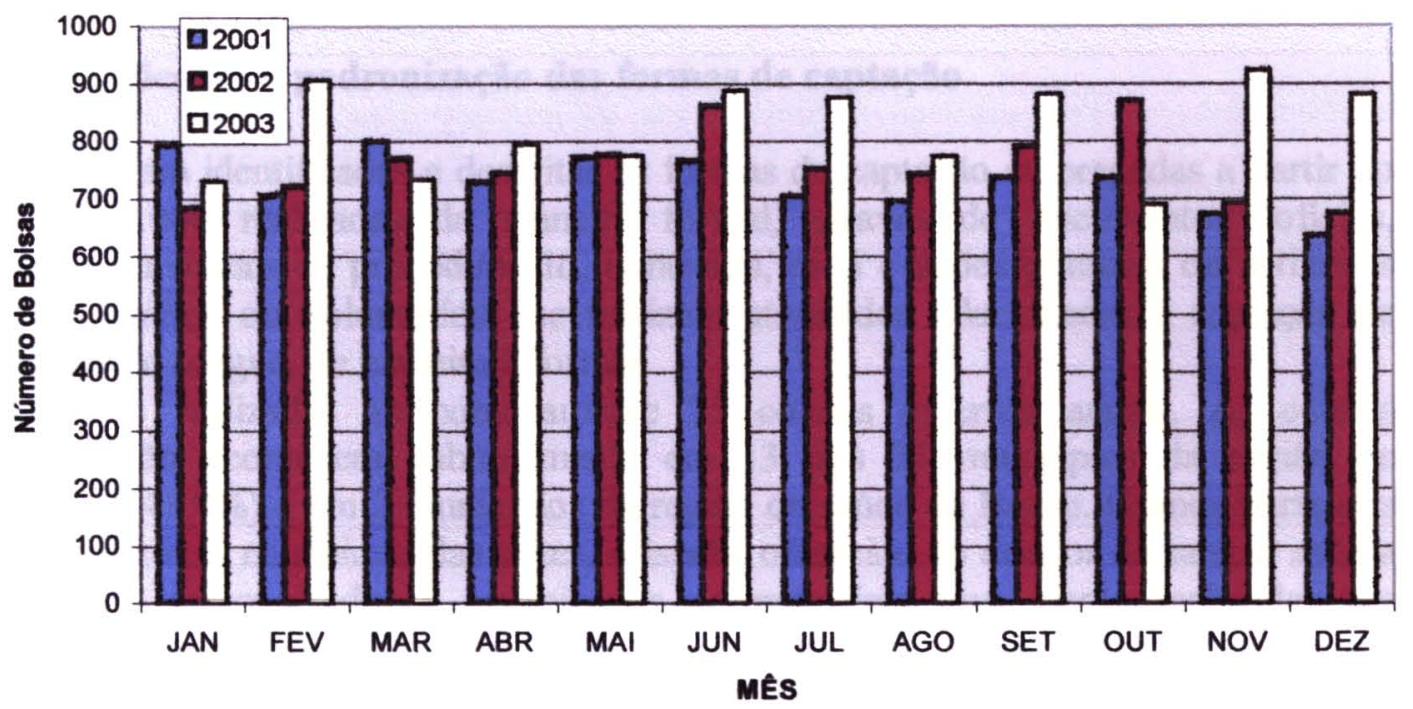

Tabela III - Distribuição do percentual de bolsas de concentrado de hemácias perdidas relacionadas ao total de bolsas utilizadas ou distribuídas. Hemocentro de Botucatu.

\begin{tabular}{|c|c|c|c|c|c|c|c|c|c|c|c|c|}
\hline \multirow[b]{2}{*}{ ANO } & \multicolumn{12}{|c|}{ MÉS } \\
\hline & JAN & FEV & MAR & ABR & MAI & JUN & JUL & AGO & SET & OUT & NOV & DEZ \\
\hline 2001 & 30,3 & 2,0 & 5,7 & 4,6 & 9,3 & 5,5 & 16,9 & 24,0 & 27,0 & 27,5 & 11,6 & 2,2 \\
\hline 2002 & 10,0 & 8,0 & 15,0 & 10,1 & 15,3 & 15,2 & 3,2 & 15,0 & 10,1 & 6,4 & 4,0 & 13,0 \\
\hline 2003 & 33,1 & 3,7 & 6,1 & 7,0 & 7,0 & 6,6 & 12,7 & 12,5 & 7,1 & 29,8 & 23,2 & 6,4 \\
\hline
\end{tabular}


Gráfico de Linhas - Distribuiçăo dos percentuais de perdas de bolsas de concentrado de hemácias relacionados ao número de bolsas utilizadas. Hemocentro de Botucatu

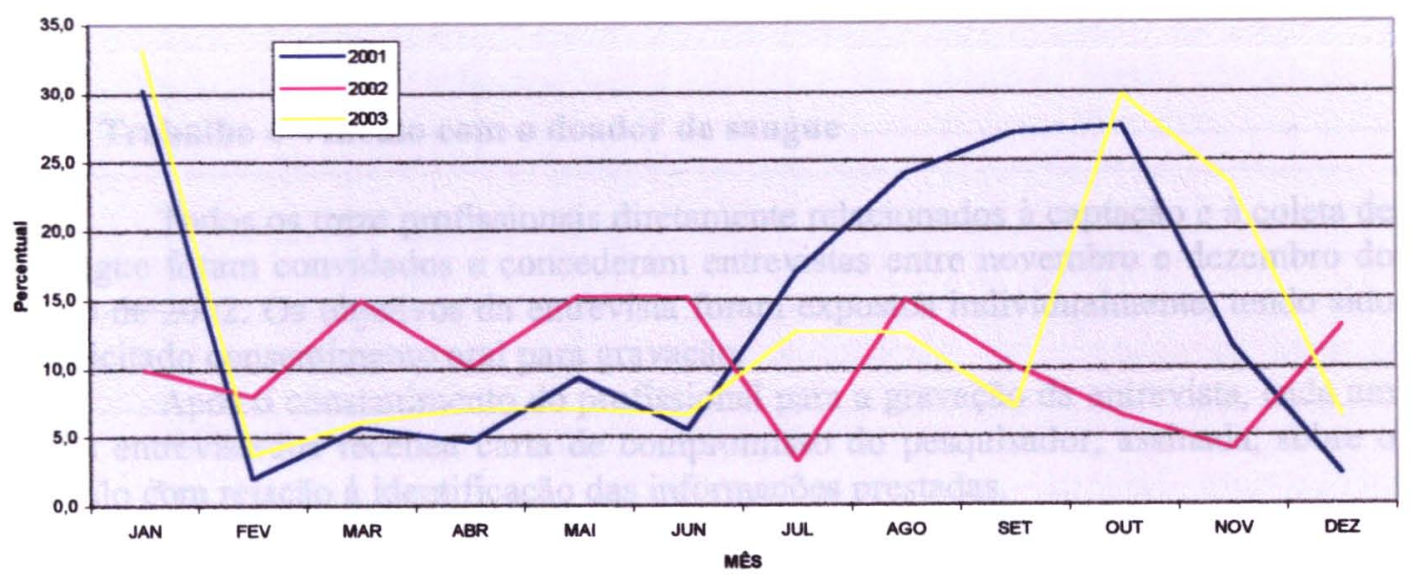

A Tabela III e o Gráfico de Linhas ilustram o percentual das perdas com relação aos concentrados de hemácias consumidos ou distribuídos pelo Hemocentro de Botucatu. Observam-se maiores perdas proporcionais nos meses de janeiro, outubro e novembro que são determinadas por períodos sistemáticos de maior incentivo à doação de sangue: festas de fim-de-ano e "semana do doador de sangue" que ocorre no final do mês de novembro.

\subsection{Identificação e padronização das formas de captação}

Foram identificadas e descritas as formas de captação empregadas a partir do ano de 2.000 realizadas de maneira formal, através de documentos (ofícios, circulares, manuais de procedimento, contratos, etc.) e ações pontuais ou rotineiras de funcionários ou voluntários que realizam atividades relacionadas à captação de doadores de sangue, de maneira informal.

São realizadas aproximadamente 25 coletas externas anuais. As coletas externas são acontecem habitualmente em 13 dos 31 municípios da região de Botucatu (41,9\%) e em 2 municípios da região de saúde de Bauru. Grande parte dos equipamentos e, na maioria das vezes, o lanche oferecido ao doador de sangue após a coleta, são transportados e organizados no município onde serão realizadas tais coletas. É necessária organização e logística com previsão dos diversos materiais, transporte de bolsas, tipos de bolsa a serem coletas, tubos para coleta de exames, materiais descartáveis e até embalagens apropriadas para o lixo. São coletadas entre 100 e 150 bolsas de sangue em cada evento.

O preparo para cada coleta externa inclui o envio de cartas a doadores habituais do município com informações sobre datas, horários e sobre o preparo necessário para a doação de sangue; também envio de cartazes, em geral para afixação nos serviços de saúde ou em pontos estratégicos de freqüência de pessoas.

Nesta atividade, são consumidos cerca de 20 cartazes e 1000 folhetos explicativos mensais. 
O tempo longo entre a coleta das bolsas e a chegada das mesmas aos laboratórios de processamento do Hemocentro obriga que o sangue seja coletado em bolsas duplas, não havendo aproveitamento de plaquetas e diminuição da qualidade dos produtos do sangue.

\subsection{Trabalho e Vínculo com o doador de sangue}

Todos os treze profissionais diretamente relacionados à captação e à coleta de sangue foram convidados e concederam entrevistas entre novembro e dezembro do ano de 2002. Os objetivos da entrevista foram expostos individualmente, tendo sido solicitado consentimento oral para gravação.

Após o consentimento do profissional para a gravação da entrevista, cada um dos entrevistados recebeu carta de compromisso do pesquisador, assinada, sobre o sigilo com relação à identificação das informações prestadas. inicial.

Nenhuma entrevista excedeu a trinta minutos, como proposto no projeto

As entrevista foram semi-estruturadas (TRIVIÑOS ${ }^{71}$ ), incluíram cinco questões relacionadas ao Vínculo (CAMPOS ${ }^{70}$ ) e às Disciplinas de Aprendizagem (SENGE ${ }^{73}$ ): raciocínio sistêmico sobre comportamento do doador de sangue, doações e consumo de hemocomponentes, domínio pessoal relacionado a seu compromisso individual, sua visão do que lhe é importante, sua competência e pontos em que considere devam ser melhorados, resistências, cinismo, felicidade, metas e objetivos, contrapondo-se sobre o que querem se livrar, visões negativas, processos e hiatos criativos; objetivos comuns incluindo visão compartilhada; modelos mentais, ressaltando arquétipos de comportamento e aprendizagem em equipe, reflexão e diálogo:

a) Você é uma pessoa que tem ou não um projeto para sua vida pessoal? Fale um pouco sobre isso.

b) Em relação a sua vida profíssional, você tem um projeto para a sua vida, ou não?

c) Entre seus colegas do Hemocentro você percebe um projeto comum de trabalho? Fale um pouco sobre isso.

d) Agora, eu queria que você falasse um pouco sobre os doadores. Eles são pessoas que têm alguma coisa em comum, ou não?

e) Como é o seu relacionamento com estes doadores? Fale um pouco sobre isso.

As entrevistas foram transcritas, foram identificadas as expressões chave, as idéias centrais e as ancoragens, seguindo-se à construção do Discurso do Sujeito Coletivo ${ }^{75}$, à semelhança das entrevistas com os dois grupos de doadores de sangue. Também foram estabelecidas medidas percentuais de força das idéias centrais (F\%). Todos os discursos e trechos aparecem com os caracteres em itálico $\left(\right.$ LEFEVRE $^{75}$ ).

A integra do Discurso do Sujeito Coletivo dos trabalhadores é apresentada nos anexos. 


\subsection{Entrevista com psicólogos}

Foram entrevistados dois psicólogos os quais desenvolveram atividades com os trabalhadores (1998-2000 e 2003), com o intuito de direcionar abordagem, terapêutica ou não, daqueles envolvidos diretamente com doadores de sangue. Os psicólogos foram interrogados sobre objetivos de trabalho, linhas terapêuticas, dificuldades levantadas e resultados. O conteúdo das entrevistas foi escrito e retornou para ser avaliado sobre sua pertinência e necessidade de correção pelos psicólogos.

As entrevistas com os psicólogos têm importância, na medida em que estes profissionais realizaram trabalho terapêutico com os trabalhadores e utilizando abordagens metodológicas distintas, ambos conduzindo suas atividades com relação a questões do Vínculo. Sendo que nova proposta de abordagem, com os trabalhadores, não pode desconsiderar o realizado anteriormente.

Informações sobre estrutura e processos (DONABEDIAN ${ }^{83}$ ), como número de trabalhadores, cargos ou funções ocupadas e escolaridade, organograma institucional, recursos materiais e financeiros, relatórios anuais de produção, relatórios financeiros da Fundação para o Desenvolvimento Médico e Hospitalar FAMESP, obtidos na área administrativa do Hemocentro, descritos na introdução, auxiliaram na caracterização dos trabalhadores e doadores.

\subsection{Pensamento Sistêmico}

As informações sobre as idéias centrais obtidas nos discursos coletivos de todos os entrevistados, com suas respectivas forças, expressas de forma percentual, foram analisadas em concomitância às entrevistas com os psicólogos e enfermeiros e às informações pertinentes relacionadas a estrutura e processo, com a finalidade de apontar ações de alavancagem que facilitassem a emergência do Domínio Pessoal, entendimento dos Modelos Mentais e que permitam o trabalho e a aprendizagem em equipe, também o estreitamento do Vínculo entre doadores e trabalhadores.

\subsection{Análise de dados}

O perfil dos doadores de sangue foi apresentado através da distribuição de freqüências e respectivas medidas descritivas dos dados (CAMPANA e col. ${ }^{72}$ ). 


\section{RESULTADOS E DISCUSSÃO}

\subsection{Considerações gerais sobre as coletas e qualidade dos dados}

Houve dificuldade inicial em obter as listagens dos doadores de sangue para a realização das entrevistas, em princípio, por problemas técnicos relacionados ao sistema de informação. Observou-se que, conforme o número de cruzamentos solicitados, o sistema tornava-se lento ou não processava as informações solicitadas.

O sistema não diferenciou as informações quanto ao local de coleta e, um dos motivos, foi a realização das coletas no centro da cidade de Botucatu, enquanto o local de coletas de sangue do Hemocentro, anexo ao Hospital das Clínicas e distante cerca de seis quilômetros do centro da cidade, estava em reformas, entre os anos de 1999 e 2000. As coletas naquele local foram notificadas como externas. Assim, foi impossível diferenciar as coletas internas das coletas externas, realizadas em escolas, empresas ou em outros locais, quando dentro do município de Botucatu.

Talvez por conseqüência desta deficiência ou dificuldade, permitiu-se observar falhas nos preenchimentos dos cadastros dos doadores, como ausência de número telefônico para contato, que foi de $9,6 \%$ dos registros nas listagens de doadores costumeiros e de $29,1 \%$ de doadores de evento único.

Observou-se, entre os 201 doadores selecionados através dos registros da listagem de doadores de evento único de doação, com os quais se conseguiu algum tipo de contato $(29,7 \%)$, que 48 destes $(23,9 \%)$ já haviam realizado outras doações além daquela indicada no registro, o que sugere que ao menos parte destes registros obtidos no sistema implantado pela empresa SBS Consultores, no ano de 2000 , não se relaciona com o banco de dados cadastrais do sistema anterior. A outra possibilidade, que justificaria o fato, seria a multiplicidade de cadastros para um mesmo doador. Há indícios de que ambos os fatos estejam ocorrendo, já que foi observado registro do mesmo doador, com doação em datas diferentes, na listagem de doadores de evento único.

A maioria dos doadores entrevistados não sabia o número de doações anteriores realizadas, sendo comuns respostas referindo-se a "mais do que" um determinado valor. Optou-se por obter esses números através do sistema de informações do Hemocentro, o Sistema SBS. Encontrou-se dado incompativel com a listagem de doadores múltiplos, visto que, a exigência para o cruzamento de dados no sistema era de, no mínimo, 6 doações no período de dois anos.

As dificuldades em realizar contatos com doadores entre os dois grupos em estudo foram maiores naquele de doadores com único evento de doação, bem menos disposto a conceder entrevista. Possível influência nos resultados, neste grupo, poderá estar relacionada à população feminina, mais disponível a participar. Vale destacar a ocorrência do evento "Gincana pela Vida", que aconteceu em meados do ano de 2000 e que teve influência significativa, como motivação inicial, apresentada sob a idéia central "Evento estimulando a doação" e com força de $26 \%$ no Discurso do Sujeito Coletivo deste grupo de doadores. 


\subsection{Perfil do doador de menor risco: doador regular ou capacitado}

O doador de menor risco, como mostram os trabalhos de LIU ${ }^{61}$, FOLLĖA ${ }^{62}$ e $\operatorname{ANJOS}^{6}$, é o doador de repetição, que se apresenta espontaneamente para doação e se apresenta regularmente ao serviço de sangue para a doação.

\subsubsection{Gênero}

As listagens obtidas pelo sistema de informações do Hemocentro mostram 83 doadores habituais, sendo 70 doadores do sexo masculino $(84,3 \%)$ e 13 doadores do sexo feminino (15,7\%). Entre os 38 doadores entrevistados, 30 foram do sexo masculino $(73,0 \%)$ e 8 doadores do sexo feminino $(21,0 \%)$. A predominância do sexo masculino é semelhante às descritas por MONTEIRO ${ }^{31}$, ANJOS ${ }^{6}$ e PILIAVIN 52

\subsubsection{Idade}

As idades variaram entre 21 e 51 anos para o sexo feminino e entre 23 e 59 anos para o sexo masculino, entre os doadores entrevistados. Na faixa etária entre 20 e 30 anos concentraram-se $34,2 \%$ dos doadores e $44,7 \%$ na faixa entre 30 e 40 anos.

Tabela VI - Distribuição das idades média, mediana e moda, do grupo de doadores freqüentes entrevistados, segundo sexo. Hemocentro de Botucatu, 2004.

\begin{tabular}{lccc}
\hline \hline & \multicolumn{3}{c}{ sexo } \\
\cline { 2 - 4 } & $\mathrm{M}$ & $\mathrm{F}$ & TOTAL \\
\hline Média & 36,3 & 31,3 & 35,2 \\
Mediana & 37 & 26,5 & 34 \\
Moda & 37 & 24 & 37 \\
\hline \hline
\end{tabular}

\subsubsection{Estado marital}

Declararam-se casados 23 doadores $(60,5 \%)$. Outros 12 doadores, solteiros $(31,2 \%)$. Os valores percentuais observados são muito semelhantes aos encontrados por ANJOS ${ }^{6}$ no Hemocentro de Botucatu, na década de 1990 , de $33,1 \%$ de solteiros e $60,1 \%$ de casados, semelhantes à população geral de doadores.

\subsubsection{Etnia}

A grande maioria dos doadores entrevistada é branca, 35 doadores, correspondendo a $92,1 \%$. Um dos doadores, negro e, dois, asiáticos. 


\subsubsection{Ocupação e escolaridade}

Declararam-se exercer profissões de nível médio ou técnico 24 dos entrevistados $(63,2 \%)$, seguidos por 5 entrevistados que exerciam profissões correspondentes ao nível universitário de escolaridade $(13,2 \%)$ e 4 , ocupados em atividades de trabalho que exigem nível elementar de estudo (10,5\%). Declararam não ter ocupação ou estarem aposentados outros 5 entrevistados $(13,02 \%)$.

A atividade econômica de 23 entrevistados empregados foi de prestação de serviços $(60,5 \%)$, sendo que 7 destes declararam exercer atividades na área da saúde.

$\mathrm{Na}$ indústria, outros 8 entrevistados $(21,1 \%)$ e, no setor agrário, apenas 2 $(5,2 \%)$. Esta distribuição é semelhante àquela divulgada pelo Instituto Brasileiro de Geografia e Estatística - IBGE, para a população economicamente ativa (PEA), do município de Botucatu: $71,9 \%$ na prestação de serviços, $24,3 \%$ na indústria e $3,8 \%$ na agricultura (IBGE, 1998 - Cadastro Central de Empresas).

A metade dos entrevistados declarou ter completado o segundo grau de escolaridade ou curso técnico profissionalizante; possuíam nível superior 5 dos entrevistados $(13,2 \%)$, outros 5 completaram o ciclo básico e 4 não chegaram a completá-lo $(10,5 \%)$. Entre os universitários, 3 tinham curso de pós-graduação: mestrado ou doutorado.

A média dos anos de estudo foi de 11,7 anos, sendo que, a mediana e a moda, de 11 anos.

\subsubsection{Doações anteriores}

Não foi possível obter a informação verdadeira sobre o total de doações, pois o sistema atual permitiu informar os registros apenas após sua instalação, em setembro de 1999.

A número de doações, por entrevistado, no período em referência, variou de 5 a 11 doações, sendo a média de 7,4 doações, a mediana, igual à moda, em 7 doações.

\subsubsection{Motivação inicial para doação - O Discurso do Sujeito Coletivo}

As motivações iniciais declaradas nas entrevistas foram extraídas de 16 idéias centrais dos discursos dos 38 entrevistados que, a seguir, são apresentadas, pela ordem de força que representaram e com o respectivo Discurso do Sujeito Coletivo, a partir da pergunta "Você já doou sangue várias vezes, não é? você lembra por que você resolveu doar a primeira vez? Fale um pouco sobre isso.":

\section{Reposição de sangue para o Hospital das Clínicas}

Foi a pedido de um amigo, para doar para uma pessoa, para um familiar, porque a mãe dele tinha sido operada, não é? e existe uma norma aqui do Hospital das Clínicas de pedir doadores para repor o sangue. Ai eu falei "vamos aproveitar não é?", deu vontade, assim: eu fui, sei lá, com a intenção de ajudar. (F:15,8\%) 


\section{Serviço militar estimulando a doação}

A primeira vez eu doei quando estava fazendo serviço militar, foi convocação quando eu fazia o "tiro de guerra", na época, soldado. O sargento que incentivava a gente pediu vários voluntários, ai fui encaminhado para doar. Eu sai do "tiro de guerra", já em noventa e oito, ai eu coloquei na cabeça que eu queria doar, assim. espontâneo mesmo. (F:13,2\%)

\section{Estímulo dos meios de comunicação à doação de sangue}

Foi voluntário, porque eu... a gente ficou sabendo, não é? a gente vê muitas matérias, a gente sempre escuta no rádio de pessoas que estão precisando e que é muito dificil, não é? que está sempre faltando sangue no hospital. A própria publicidade, de falar da necessidade de doação de sangue, falta de sangue, banco de sangue, que uma doação salvava quatro vidas... conscientização, que têm muitas pessoas precisando. Aí eu resolvi ser voluntária na doação. (F:13,2\%)

\section{Estímulo de parentes ou amigos para a doação de sangue}

Vendo meu pai doar sangue, aquilo foi me motivando, não é? meu pai que doa bastante. Eu cresci com isso e meu pai falava "não, vamos doar, vamos doar". Um amigo meu já tinha doado sangue e encorajou, falou como que é, que não tinha problema nenhum, a minha irmã desceu e falou para mim "ó... estão precisando de 'O negativo' lá no Hemocentro" e... falou "vamos lá?" então: fui. (F:10,5\%)

\section{Solidariedade}

O motivo maior foi a vontade, não é? o voluntarismo de querer ajudar as pessoas, ajudar às pessoas que necessitam, porque eu acho que tem bastante gente que precisa, não é?. (F:10,5\%)

\section{Atividade comunitária ou em organizações sensibilizando à doação de sangue}

Minha religião, que incentiva as pessoas a fazer este ato de caridade. Quando eu fiz escotismo, então tinha essa vontade de... tinha a vontade de exercer, não é? ser voluntário... foi parte do trote de quando eu entrei no curso, na faculdade $e$, todos acabaram doando e eu entrei nessa e doei também. Onde eu trabalhava naquela época, nós fizemos um conjunto de pessoas e resolvemos ir doar sangue. (F:10,5\%)

\section{Evento catastrófico sensibilizando para a doação de sangue}

Ajudar um amigo que estava precisando, de um acidente, um acidente muito grave que, na época, ocorreu na empresa, não é? e a gente foi convidado para... essa doação. Também, tinha uma irmã que faleceu com câncer, e eu acompanhei muito tempo. Em cada doação... que ela recebia transfusão, ela melhorava sensivelmente. (F:7,9\%) 


\section{Divulgação e coleta externa de sangue em empresas}

Teve uma campanha na empresa que eu trabalho, não é? então, pediram para mim, lá e... eu achei bom, achei interessante. (F:7,9\%)

\section{Espontaneidade}

Foi espontâneo mesmo, não tinha motivo de ter. Foi vontade própria: eu decidi doar e fui doar. (F:5,2\%)

\section{Serviço de saúde sensibilizando para a doação}

Fiquei lá no hospital, vendo as pessoas que... que passavam, essas pessoas que necessitavam de sangue. Voluntária mesmo, pela própria dificuldade que a gente via, da dificuldade do Hemocentro, de doadores. (F 5,2\%)

\section{Curiosidade sobre doação de sangue}

Foi por curiosidade, eu... resolvi doar pela primeira vez, não é? a curiosidade do que era uma doação de sangue e, também, aproveitei uma dispensa do trabalho. (F 5,2\%)

\section{Informar-se para a doação}

Eu procurei me informar sobre com quantos anos eu poderia doar, peso... tudo certinho. (F 2,6\%)

\section{Palestra sobre a importância como fator desencadeante da doação de sangue}

Para a doação teve uma palestra que foi um (...) quem foi fazer a palestra, mas falou relativamente da importância do sangue. (F 2,6\%)

\section{Conhecer o tipo sangüineo}

Saber o tipo de sangue, o tipo sangüineo.(F 2,6\%)

\section{Realização de testes sorológicos}

Foi por envolvimento com uma pessoa, uma menina que não era muito certa das idéias... tem que tirar esse peso da consciência. (F 2,6\%)

Tiveram, como motivação inicial para doação, neste grupo de doadores, principalmente algum tipo de pressão social, correspondendo a $\mathbf{7 6 , 3} \%$ das respostas dos doadores, incluindo a categoria de reposição $(15,8 \%)$, que é considerada por PILIAVIN ${ }^{52}$ como outra categoria motivacional. Solidariedade e humanitarismo representaram $23,6 \%$ das motivações, sendo que 5,2 \% dos doadores relataram recompensas ou benefícios pessoais como motivação inicial para a doação de sangue. 
Observa-se que as duas motivações para a primeira doação, com maior força no discurso, somaram $29,0 \%$ e que não revelam, em princípio, que necessariamente deva existir sentimento altruísta ou de solidariedade como motivação consciente inicial para a doação, como nos casos do estímulo para reposição de sangue para o Hospital das Clínicas e o estímulo nas atividades do "tiro de guerra". Também, pela doação de sangue por curiosidade, para conhecer o "tipo sangüíneo" ou para a realização de testes sorológicos. Contudo, estas motivações iniciais desencadearam várias doações posteriores.

Isto sugere que a população geral, independentemente do grau de informação sobre o assunto doação de sangue, obedece gradiente que vai da indiferença: por maior e qualificada que seja a informação, não há estímulo que desencadeie a doação de sangue; até a doação freqüente e praticamente sem ou quase sem estímulos: espontaneidade.

Se estas hipóteses são verdadeiras, a implicação administrativa ou estratégica do Hemocentro será a de identificar o doador em primeira doação e tratá-lo com a consciência de que doações posteriores independem do motivo que o trouxe a realizar a primeira doação, ou seja: qualquer que seja a motivação inicial, mais ou menos altruísta, poderá desencadear doações múltiplas futuras.

\subsubsection{Motivação para voltar a doar - O Discurso do Sujeito Coletivo}

As motivações para voltar a doar ou, para as várias doações seguintes deste grupo de doadores concentraram-se em 9 idéias centrais encontradas nas diversas entrevistas, apresentadas aqui, também, acompanhadas do Discurso do Sujeito Coletivo, em ordem, segundo sua força no discurso, em resposta à pergunta " $E$ as outras vezes? Você doou pelos mesmos motivos, ou não?":

\section{Altruismo e solidariedade}

Eu faço assim como... de livre e espontânea vontade, nunca foi por outra... sempre foi para ajudar o próximo, simplesmente pelo motivo de estar ajudando alguém, solidário nas pessoas que necessitavam do meu tipo de sangue, por um altruismo, para continuar doando, ajudando, não é? às vezes, até a salvar a vida de uma pessoa, porque as pessoas precisavam. Vontade própria, mesmo, pelos mesmos motivos humanitários que eu acabei doando e pude fazer isso várias vezes. Eu sou doador, então dou continuidade até o dia que eu puder doar, acompanhando o periodo de poder doar, a cada três... quatro meses. (F:63,2\%)

\section{Consciência da necessidade de doar sangue}

Comecei a me conscientizar, com as campanhas, que os hospitais precisavam de sangue, que a gente precisa ajudar no banco de sangue, nas cirurgias, porque eu sabia que é dificil, eu conheço os mecanismos de doação, eu conheço os pacientes eu sei que é importante doar sangue. A gente sabe a grande necessidade, a falta, não é? do sangue no banco de sangue. Depois que eu conheci, não vi problema algum, não $e ́$ ? e, até gostei da idéia, ai eu vim voluntariamente. (F:36,8\%) 


\section{Espontaneidade}

Sim, espontâneo; nunca porque tinha parente internado. Voluntária, não é? eu ia porque eu queria mesmo. Dava vontade... vontade de doar, mesmo, sem precisar ajudar, mesmo, mas já ajudando, não é? a cada quatro meses aí.. eu estava lá, porque vi, nesta primeira vez, que não tinha nada de mais, não doía, não arrancava pedaço, não tinha nem um mal e, que eu podia fazer isso é... sem problemas.(F:18,4\%)

\section{Solicitação de amigos ou familiares para reposição de sangue}

Sabendo que eu doava sangue, quando as pessoas faziam algum tipo de cirurgia eles acabavam me pedindo, também quando parentes, amigos precisavam de doação de sangue... que tinha parentes no hospital e, eles pedem dez doadores, não é? para reposição. $(\mathbf{F}: \mathbf{1 8 , 4} \%)$

\section{Sensação de bem-estar}

Cada vez que eu dôo, eu me sinto outra pessoa. Parece que renova alguma coisa dentro da gente. Sei lá... a gente se sente bem melhor, também. Certo? acho que eu me sinto bem; mas, na verdade, é porque eu gosto, mesmo. (F:10,5\%)

\section{Possibilidade de precisar de sangue para si mesmo}

Eu sei que de repente pode ser que eu precise, um dia, do sangue de alguém. Eu me ponho no lugar das pessoas: vamos dizer que eu precisasse do sangue e não tivesse, eu poderia até morrer... (F:5,2\%)

\section{Boa saúde}

Eu falava para o pessoal, um sangue bom, livre de colesterol, livre de tudo, então, tinha que aproveitar. (F:2,6\%)

\section{Exames laboratoriais realizados com o sangue do doador}

O principal de tudo isso, também, aqui, pelo meu ponto de vista é... que pelo menos eu estou a par... assim, um "check up" geral do sangue. (F:2,6\%)

\section{Reconhecimento por parte do receptor da importância do doador de sangue}

O pai da criança que estava fazendo cirurgia foi lá atender, receber a gente legal, foi abraçar a gente, cumprimentar... motivou mais, para continuar doando (F:2,6\%)

A comparação entre a motivação inicial e a motivação para as doações posteriores, mostra que solidariedade e humanitarismo evoluiu de $23,6 \%$ para $63,2 \%$, enquanto houve regressão na motivação de pressão social de $76,3 \%$ para $18,4 \%$. Surgiu, entre as motivações para tornar a doar, outra categoria importante 
citada por PILIAVIN ${ }^{52}$, a motivação pelo bem-estar, com 10,5\%. A motivação por benefícios pessoais foi citada por $7,8 \%$ dos entrevistados. Destaca-se outra categoria, não citada por PILIAVIN ${ }^{52}$, a motivação desencadeada pela consciência da necessidade da doação de sangue, com $36,8 \%$ de afirmações entre os entrevistados.

O estudo de FERNÁNDEZ-MONTOYA ${ }^{55}$ sobre como foi a evolução das atitudes, crenças e motivações dos doadores de sangue na Espanha, quando acompanhou grupo durante sete anos, entre 1987 e 1994, utilizou metodologia diferente, somente com questões fechadas e trabalhando com valores estatísticos das respostas. Nas discussões, o autor mostra que a primeira motivação é altamente valorizada pelo doador e que as motivações, depois de sete anos, eram as mesmas do início e que essas motivações respondiam por expectativas e crenças profundamente enraizadas no indivíduo. Mudanças nas motivações resultaram no direcionamento para solidariedade e dever.

No presente trabalho as idéias centrais de motivação reduziram-se de 16 para 9 idéias. Também, observou-se que a idéia central de solidariedade (F:10,5\%) evoluiu, ganhou força em altruísmo e solidariedade (F:63,2\%) e consciência da importância de doar sangue (F:36,8\%), como descrito anteriormente.

Houve referências, pelos doadores, de que, mesmo doando espontaneamente, muitos deles atendem convites de parentes e amigos para reposição. Essa idéia central de reposição foi citada com força de $18,4 \%$. Este fato indica a necessidade de rever a forma de coleta de dados dos doadores e confirma as conclusões de ANJOS ${ }^{6}$ sobre a qualidade das doações de reposição que é influenciada diretamente por doadores voluntários de menor rejeição sorológica. Mesmo com esta influência, existem diferenças significativas de qualidade do sangue coletado, com relação à rejeição sorológica, entre doadores de reposição e doadores voluntários espontâneos freqüentes ${ }^{6}$.

\subsubsection{Problemas ou dificuldades para a doação - O Discurso do Sujeito Coletivo}

Dando continuidade à apresentação dos discursos, apresenta-se as idéias centrais das respostas à pergunta "Nestas vezes que você doou, houve algum problema, alguma coisa que dificultou a doação, ou não?":

\section{Ausência de dificuldades ou problemas}

Aqui, nunca senti dificuldades. Todas as vezes eu cheguei, doei, sem problema nenhum. Sabia já das coisas que precisava estar, assim, para doar, os quesitos básicos para doar, então: sem problema nenhum. Muito fácil de encontrar a veia, bombeamento perfeito... nunca aconteceu nada, nem antes e nem depois da doação. Nem vazamento, nada, nada. Nunca me senti mal, sempre correu tudo bem, sempre que eu vou lá sou bem atendido... sempre bom, sempre tranqüilo, graças a Deus! Tenho medo, até hoje, de ver a agulha entrar no meu braço. Depois que a moça "coloca lá", normal. Bem estruturado, bem estruturado o Hemocentro... as coisas são bem tratadas, o pessoal trata a gente bem. A recepção é muito agradável, eles te acolhem muito bem, tem uma preocupação enorme se você está bem, não é? se você se alimentou antes da doação, se você está bem de saúde, paparicando a gente e tal. (F:81,5\%) 


\section{Acidente de punção}

Fui fazer a doação e, na hora que eu recebi a agulha, no braço direito, eu acho que a moça era inexperiente, tá? ela insistiu que a veia do braço direito era mais... melhor, não é? a moça não estava encontrando a minha veia, então ela colocou a agulha, só que, em vez de ela retirar a agulha inteiramente e colocar, ela tentou dar uma acertadinha, a moça "pegou o nervo", não é? do braço que... que fiquei assim: meio assustado, não é? então, o braço ficou um pouquinho inchado; $j a ́$ aconteceu duas vez. Uma vez que... uma perfuração da minha veia, que eu falei "tudo bem" e houve um derrame muito grande, que ficou muito roxo o derrame que deu. Quando a moça foi arrancar a mangueira para colher o pouco de sangue para fazer os exames, ali, ela derramou um pouco daquilo no meu braço... uma certa impericia dela ou um descuido na hora, ali. (F:10,5\%)

\section{Mal-estar após a doação de sangue}

A segunda vez que eu doei sangue só que... eu acho que a minha pressão baixou demais, que eu fiquei pálido. Foi bem após à doação, eu tinha feito a doação lá na UNESP, mesmo e, após ter chegado aqui na cidade é que eu passei mal, eu "apaguei" um pouco (F:7,8\%)

\section{Demora no atendimento decorrente do número de doadores}

Teve uma ou duas vezes que eu vim, tinha muita gente, então demorou um pouco e... eu não gosto de esperar. (F:2,6\%)

\section{Chamada do doador por alteraçäo em exame sorológico}

Ligaram, não é? dizendo para mim voltar lá por causa que eu tinha que fazer novos exames que foi pelo fato de eu ter tomado, há um tempo antes, vacina contra febre amarela. (F:2,6\%)

\section{Problemas administrativos do Hemocentro dificultando a doação de sangue}

Fui chamada para doar plaquetas, não é? foram me buscar na data errada... eu não podia, não é? (F:2,6\%)

\section{Dificuldade de acesso ao local para doação de sangue}

O que eu falo para todo mundo: gostaria que o posto fosse de atendimento mais próximo do centro, que a gente comenta muito isso aí, para quem é doador da cidade. (F:2,6\%)

\section{Importância do vínculo entre doador e trabalhador do Hemocentro}

No começo eu era conhecido de todos os funcionários, então, não tinha pesquisa, não tinha quase nada, o pessoal conhecia, sabia a idoneidade da gente. (F:2,6\%) 


\section{Rejeição clínica provisória}

Tomei uma vacina, não é? aquela... acho que é rubéola, não sei o que é que foi lá, e, dai, eu não pude doar. (F 2,6\%)

\section{Perda do dia de trabalho por causa da doação}

O único problema era por causa do serviço, porque a empresa ela... as empresas, hoje, elas aceitam um atestado por ano, de doador... de doação de sangue, não é? então, eu sempre doava... dôo, não é? três vezes ao ano, dois eu perdia, quer dizer, eu perdia três dias, não é? que a gente perde o dia da semana, o sábado e o domingo. $(\mathbf{F}: \mathbf{2 , 6 \%})$

Identificaram-se dez idéias centrais, destacando-se a força de $81,5 \%$ nos discursos sobre a idéia central de ausência de dificuldades ou problemas para a doação de sangue.

Algumas da idéias centrais identificadas como problemas: acidentes de punção (F:10,5\%), demora ou espera prolongada pelo doador (F:2,6\%) e dificuldade de acesso ao serviço ( $F: 2,6 \%$ ), excetuando-se situações raras ou incomuns e inevitáveis, são situações que merecem treinamento, atenção em altos níveis e políticas da universidade ou da Faculdade de Medicina, como força maior do Hemocentro, para facilitar o local de acesso às doações de sangue.

O controle dos acidentes de punção, através de sistema de notificação, pode ser valioso instrumento potencializador da atenção nesses procedimentos. Também para controle e seleção de estagiários flebotomistas.

Os problemas e acidentes relatados, contudo, foram minimizados nos discursos. Extraiu-se idéia central apresentada a seguir, sem relação direta com a pergunta feita, mas que marca característica fundamental de perseverança no propósito da doação de sangue:

\section{Percepção diminuida de problemas ocorridos durante ou após a doação de sangue.}

Era o único problema, foi só isso. Foi, assim, coisa passageira; mas, mesmo assim, eu persisti, insisti e fiz a doação no braço esquerdo, dai. Foi a única vez... das outras tudo correu normal, são vinte... vai fazer vinte anos que eu dôo sangue o resto foi tudo normal. Só isso aí; mas, assim, quanto ao atendimento, nenhum. Depois disso nunca mais aconteceu nada. mas ficou normal, correu tudo normal, graças a Deus, tudo normalmente. (F:26,3\%)

Este trecho do discurso demonstra o alto grau de motivação deste grupo de doadores, que supera dificuldades que seriam, muito provavelmente, fatais no comprometimento de novas doações, se ocorressem com doadores em sua primeira doação de sangue. 


\subsection{Perfil do doador de maior risco: doadores com único evento de doação}

O doador de sangue que apresenta maior risco de transmissão de doenças através da via transfusional é o doador de que realiza sua doação pela primeira vez e de maneira a repor os estoques de sangue ao hospital, solicitado por parente ou amigo internado $61,62,6$.

\subsubsection{Gênero}

Apresentou-se listagem com 676 doadores que realizaram um único evento de doação, sendo $425(62,9 \%)$ do sexo masculino e 251 (37,1\%) do sexo feminino descontados aqueles os quais obteve-se a informação de que realizaram outras doações. Entre os 26 entrevistados, $46,2 \%$ foram do sexo masculino com conseqüentes $53,8 \%$ do sexo feminino. Houve número proporcionalmente maior, de indivíduos entrevistados do sexo feminino neste grupo, comparado com o grupo de doadores freqüentes, apresentado anteriormente.

\subsubsection{Idade}

Neste grupo, as idades variaram entre 21 e 39 anos para os doadores entrevistados do sexo feminino e, entre 21 e 51 anos, no sexo masculino.

Tabela V - Distribuição das idades média, mediana e moda, do grupo de doadores em único evento entrevistados, segundo sexo. Hemocentro de Botucatu, 2004.

\begin{tabular}{lccc}
\hline & \multicolumn{3}{c}{ sexo } \\
\cline { 2 - 4 } & $\mathrm{M}$ & $\mathrm{F}$ & TOTAL \\
\hline Média & 30,2 & 27,5 & 28,8 \\
Mediana & 28 & 27 & 28 \\
Moda & 28 & 29 & 28 \\
\hline \hline
\end{tabular}

Observa-se que há diferenças nas idades entre os doadores do sexo masculino, em comparação aos doadores freqüentes entrevistados, de aproximados 9 anos.

\subsubsection{Estado marital}

Neste grupo, declararam-se casados 12 doadores $(46,2 \%)$. O maior número de doadores declarou-se solteiro, 13 doadores $(50,0 \%)$, bem acima da proporção de solteiros do grupo de doadores freqüentes. Apenas um doador declarou-se viúvo $(3,8 \%)$.

\subsubsection{Etnia}

Com relação à etnia, 24 doadores deste grupo são brancos, com percentual correspondente de $92,3 \%$, semelhante ao grupo de doadores freqüentes, sendo que um doador é negro e outro é asiático. 


\subsubsection{Ocupação e escolaridade}

Entre os 23 doadores entrevistados que se declararam com emprego, encontrou-se 7 doadores empregados em atividades que exigem somente nível elementar de escolaridade $(30,4 \%), 11$ entrevistados em atividades de nivel médio $(47,8 \%)$ e 5 em atividades de nivel superior $(21,7 \%)$.

Com relação às áreas da economia, encontrou-se 20 doadores exercendo atividades no setor de prestação de serviços $(87,0 \%)$ e outros 3 relacionados ao setor industrial $(13,0 \%)$. Vale destacar que, neste grupo de doadores, não se encontrou profissionais em atividades relacionadas à saúde.

Em relação aos anos de estudo, a média foi de 12,5 anos, a mediana de 11 anos e, a moda, também de 11 anos.

De maneira semelhante ao grupo de doadores freqüentes, $50 \%$ dos doadores do grupo de doadores de evento único de doação apresentaram o segundo grau de escolaridade, $30,8 \%$ nível superior de escolaridade e os outros $19,2 \%$ completaram ou não o ciclo básico de escolaridade. Apenas um, dos doadores com nível universitário, relatou estar realizando curso de pós-graduação.

Observa-se que, em termos de anos de estudo, ambos os grupos, de evento único de doação e de doações freqüentes, são muito semelhantes.

\subsubsection{Motivação para doação - O Discurso do Sujeito Coletivo}

Selecionaram-se 12 idéias centrais relacionadas à pergunta "Na sua ficha, eu vi que você doou sangue só uma vez, não é? por que você resolveu doar?" nos discursos individuais dos 26 doadores entrevistados. Estas idéias centrais são apresentadas em ordem decrescente relacionada à força de cada idéia no discurso.

\section{Evento estimulando a doação}

Era uma gincana, na escola, na época, não é? e eu tive a oportunidade, as escolas daqui de Botucatu: municipais, estaduais, até as particulares estavam fazendo campanha e, eu resolvi entrar na campanha também, para dar o ponto para a escola da minha filha. Eu fiz um concurso para a policia militar e, um dos critérios para você estar passando à frente da fila, porque a fila é muito grande, foi: você doar o sangue para você estar passando na frente nos exames, não é? (F: 26,9\%)

\section{Estímulo de amigo ou parente para a doação de sangue}

Eu fui acompanhar uma amiga que ia doar, ai eu acabei doando. O incentivo da minha mãe, também, não é? minha mãe sempre doa. A diretora da minha escola me reconheceu, na rua, e me pediu a ser voluntária, a doar sangue e tal... Meu primo era estudante de medicina e ele que veio com essa proposta "oh, vamos doar, pro pessoal?" eu resolvi doar. (F: 15,4\%) 


\section{Intenção de doar sangue}

Olha, eu sempre tive vontade de doar, certo? Foi por vontade própria, eu tinha essa intenção; assim que eu subi o peso, eu vi a chance de doar. (F: 15,4\%)

\section{Solidariedade}

Eu queria ajudar, mesmo, na doação, uma coisa tão simples. Estava na semana de natal e foi mais com a intenção de fazer uma boa ação, porque tem muita gente que precisa. (F:11,5\%)

\section{Evento catastrófico ou doença estimulando a doação de sangue}

Um amigo meu, que trabalhou comigo e ele teve leucemia, não é? e, eu vi que ele precisava. Houve um acidente, na fábrica, com nosso amigo e precisavam de bastante sangue, foi o motivo meu, particular, de doar sangue. Conheço ele de muito tempo. (F: 11,5\%)

\section{Estímulo e facilitação do serviço de saúde}

Eu estava trabalhando ai eles foram na firma buscar, de perua, trouxeram até aqui que era aqui na esquina da "Misericórdia". A escola combinou... naquela época ligou e pediu que tivessem alunos que pudessem doar mais por isso mesmo: pelo grupo e pela escola, para ajudar na doação de sangue. (F: 7,7\%)

\section{Estímulo dos meios de comunicação à doação de sangue}

Eu resolvi doar porque eu via várias propagandas sobre doação de sangue. Um incentivo, não é? da televisão, para doar sangue. (F: 7,7\%)

\section{Realização de testes sorológicos}

Eu aproveitei para doar, para e saber se está tudo em ordem comigo, sabe? para fazer um check-up geral, não é? Aproveitar que a UNESP oferece o serviço. (F: 7,7\%)

\section{Possibilidade de precisar de sangue para si mesmo}

Eu não sei meu dia de amanhã, não é? quem sabe, eu posso precisar de alguém que doe para mim, não é? (F: 3,8\%)

\section{Serviço militar estimulando a doação de sangue}

Lá no quartel, não é? o sargento, ele conversava bastante com a gente, para a gente doar e tal, $(\mathbf{F}: \mathbf{3 , 8 \%})$ 


\section{Facilidade de acesso ao local para a doação}

Pela oportunidade do local. (F: $\mathbf{3 , 8 \%}$ )

\section{Doar sangue para salvar vidas}

Um gesto de salvar uma vida, não é? (F: 3,8\%)

Observa-se que, a primeira doação deste grupo, apresenta como principal motivação a pressão social, com $61,5 \%$, seguida da solidariedade e humanitarismo com $26,8 \%$. A motivação por recompensas ou benefícios pessoais foi de $11,5 \%$. Destaca-se que, apesar de haver algumas diferenças nas motivações e nos discursos entre o grupo de doadores freqüentes e o grupo de doadores em evento único, a distribuição percentual das motivações são semelhantes, para a primeira doação.

Comparando-se os dois grupos entrevistados de doadores, com relação às motivações iniciais para a doação, obteve-se oito idéias centrais coincidentes:

Tabela VI - Distribuição das Idéias Centrais de motivação inicial para a doação de sangue sequndo a força no Discurso do Sujeito Coletivo, por grupo de doadores. Hemocentro, 2004.

\begin{tabular}{lcc}
\hline \hline \multicolumn{1}{c}{ Idéia Central } & Doadores Freqüentes & Doadores Evento Único \\
\hline Estimulo de parentes ou amigos & 10,5 & 15,4 \\
Solidariedade & 10,5 & 11,5 \\
Estímulo dos meios de comunicação & 13,2 & 7,7 \\
Espontaneidade & 5,2 & 15,4 \\
Estimulo por evento catastrófico & 7,9 & 11,5 \\
Serviço Militar & 13,2 & 3,8 \\
Estimulo de Serviços de Saúde & 5,2 & 7,7 \\
Realização de Testes Sorológicos & 2,6 & 7,7 \\
\hline TOTAL & 68,3 & 80,7 \\
\hline \hline
\end{tabular}

Houve 11 idéias centrais não coincidentes, correspondendo à força de 47,2\% e de $38,3 \%$, respectivamente nos grupos de doadores freqüentes e no de doação única.

Ressalta-se, na Tabela VI, o grande percentual de forças de motivação coincidentes, em ambos os grupos de doadores, o que reforça a necessidade de melhorar o acolhimento e corresponder às expectativas dos doadores para aumentar 0 número de retenções entre os doadores de sangue. 


\subsubsection{Motivos para não tornar a doar - O Discurso do Sujeito Coletivo}

Foram obtidas 14 idéias centrais em resposta a pergunta "Daí você não dou mais, não é? por que? Fale um pouco sobre isso." As idéias centrais são apresentadas a seguir, com o respectivo conteúdo, dentro do Discurso do Sujeito Coletivo, também apresentadas as forças destas, em ordem decrescente, como nos discursos anteriores.

\section{Falta de tempo, esquecimento, falta de oportunidade ou de estímulo}

Falta de tempo, a correria do dia-a-dia, a gente nunca teve a oportunidade: quando via, já passava o tempo, passava o ano e eu não conseguia ir até o Hemocentro doar sangue. Eu estava trabalhando demais, por isso. Sou um cara acomodado demais, quer dizer, o defeito mais brasileiro. Então, foi, tipo, um esquecimento meu. "amanhã eu vou doar sangue", é uma coisa tão fácil; então, aquilo: deixa para amanhã. Amanhã ou depois; então, vai... passou. Como você ligou (entrevistador), eu estou disposto a doar sangue hoje, amanhã; mas, é aquilo: vou assumir um compromisso com você, amanhã eu vou lá doar. E, também por falta de... sei lá: às vezes, se me ligassem e falassem "vem, nós estamos precisando que você doe", alguma coisa nesse sentido, não é? de incentivar a pessoa, de lembrar a pessoa, nunca mandaram carta para mim, nada... eu teria ido. (F: 30,8\%)

\section{Distância ou dificuldade de acesso}

Eu fui doar estava na "Doutor Costa Leite" (rua) e, depois, voltou tudo a ser na UNESP, então, para mim, ficou mais longe não tinha facilidade para locomoção até lá: para mim ficou mais dificil, um pouco inviável. O Hemocentro, aqui no centro de Botucatu, ia ser bem mais fácil para a gente estar doando; eu acho que para todo o mundo, não é? É dificil o acesso até a UNESP, não é? Muito longe. Este problema de deslocação, você acaba perdendo uma tarde inteira e isso dificulta bastante. (F: $\mathbf{2 3 , 1 \% )}$

\section{Problemas de saúde ou uso de medicamentos}

Depois, eu tive uns problemas de saúde, eu comecei a fazer um tratamento com uns remédios, não doei mais. Pelo motivo, assim, de eu ter rinite alérgica, então era constante, você entendeu? é muito baixa a resistência da gente. Também, um acidente que eu tive, de trabalho, eu estava tomando uma medicação muito forte, dai eu... uma vez eu fui lá para doar. (...) perguntou se eu estava tomando remédio, eu falei o nome do remédio e ele falou que eu não podia doar mais, até que parasse de tomar esse remédio. Ainda, porque, no meu sangue, deu traço falciforme, dai falaram para mim que eu não podia.(F: 19,2\%)

\section{Gravidez ou amamentação}

Logo depois que eu fiz essa doação eu engravidei, ai eu perdi... eu fiquei grávida uns dois meses, perdi. Ai, depois de um tempo, eu engravidei de novo, então, 
nesse periodo todo, da primeira doação até agora. Na gestação não pode doar, não $e ́$ ? e, eu parei de amamentar em setembro do ano passado. (F: 15,4\%)

\section{Medo depois de mal-estar após a doação}

Por causa da sensação que eu tive, porque eu passei mal, não é? eu tive um desmaio: foi logo depois que eu doei. Dai, eu fiquei com medo: nunca mais eu fui, nunca mais procurei. (F: 11,5\%)

\section{Sem motivo em especial}

Então... não tive por quê... não fui mesmo doar. (F: $\mathbf{3 , 8 \%})$

\section{Acidente ou perda de sangue}

Eu sofri um acidente, não é? perdi muito sangue, (F: 3,8\%)

\section{Medo do contágio de doenças como a AIDS}

Eu fiquei pensando, porque a gente fica pensando muito em AIDS, em contágio de AIDS, a gente fica meio com tabu, assim, não é? a gente vai lá doar sangue e fica com receio... de repente eles usam uma sering a contaminada, alguma coisa assim. Então, eu não procurei mais doar sangue. (F: 3,8\%)

\section{Medo do ato de doar ou da agulha}

$\mathrm{Na}$ verdade, eu fiquei um pouco nervoso, na época. Eu fiquei meio que com medo, certo? Porque nunca tinha feito isso, então eu vi aquela mangueira cheia de sangue me deu... nossa! Fiquei meio assustado, mas... não sei, de repente não... eu falei, "eu não vou doar mais", tal... não deu vontade mais, sabe? (F: 3,8\%)

\section{Hemocentro fechado para doação de sangue}

Um dia que eu fui lá, que eu tinha aproveitado visitar uma pessoa, lá... o dia que eu fui, estava fechado. Não tive como, não tive como doar, não é? (F: 3,8\%)

\section{Erro de triagem clínica induzindo o doador a apresentar mal-estar}

Ai, teve um dia que eu estava mal, assim, mesmo com insônia, dai eu tinha ido lá e acabei sendo liberado para doar sangue, passei mal, não é? e travou minhas mãos, assim, meus braços, assim, as pernas... passei muito mal (F: 3,8\%)

\section{Doação de sangue determinando problemas no trabalho}

Pelo serviço meu, no caso, assim: não aceitam doar sangue e ter que trabalhar. No caso, se eu doar sangue e ter o meu dia livre, eu não ir no serviço, vão ficar falando, vão ficar argumentando, perguntando o porquê (F: $\mathbf{3 , 8 \%})$ 


\section{Doações realizadas em outros serviços de sangue}

Mas eu doei em um hospital em São Paulo, na minha faculdade sempre tem gente que pede, lá... doadores voluntários, então, lá, eu acabei doando. (F: $\mathbf{3 , 8 \%})$

\section{Demora no atendimento ao doador ou na doação de sangue}

O processo de doação de sangue, ele é muito demorado, o atendimento, apesar de ser bom, demora um pouco, (F: $\mathbf{3 , 8} \%)$

O trabalho de revisão das motivações de impedimento para doação de sangue, realizado por OSWALT ${ }^{67}$, mostra o medo como principal fator de impedimento para doações, destacando-se o medo da agulha, da visão do sangue, tonturas, fraquezas, baixa de pressão sangüínea e a picada do dedo. Neste estudo, esta categoria teve força de 22,9\% no discurso dos doadores.

Problemas médicos caracterizam a segunda maior causa de desmotivação para a doação de sangue, segundo OSWALT ${ }^{67}$, que corresponderam a $\mathbf{3 4 , 6 \%}$ das idéias centrais dos discursos. Não se constatou, nestes discursos, falsas motivações para não doar relacionadas a problemas médicos.

A terceira motivação para não doar, citada por OSWALT ${ }^{67}$, foi de reações após a doação, que tiveram peso, neste trabalho, de $\mathbf{1 5 , 3 \%}$.

Contudo, a principal dificuldade para não doar, encontrada no discurso dos doadores, foi de falta de tempo, esquecimento, falta de oportunidade ou de estímulo, que teve peso de $\mathbf{3 0 , 8 \%}$, o que registra a necessidade real em se criar métodos e formas de contato que facilitem de alguma maneira a vinda destes doadores, em local para fácil doação de sangue.

A distância, ou dificuldade de acesso, especificamente, apresentou-se como desmotivação para a doação de sangue, com peso de $\mathbf{2 3 , 1} \%$ nos discursos dos doadores em evento único de doação. Reforça situação citada anteriormente de se ter diretriz política para a criação de posto de coleta de sangue localizado em região central do município de Botucatu e que se caracteriza como problema específico do Hemocentro de Botucatu.

\subsection{Otimização de custos}

Levantamento dos custos, diretos e indiretos, foi realizado por ALVARADO ${ }^{81}$ em 2001, no Hemocentro de Botucatu, relacionados ao processo de obtenção de hemocomponentes, onde aponta os procedimentos e respectivos valores:
a) Recepção e Triagem Clínica
$\mathrm{R} \$ 3,14$
b) Coleta
$\mathrm{R} \$ 17,93$
c) Processamento
$\mathrm{R} \$ 5,05$
d) Exames Imunoematológicos
$\mathrm{R} \$ 30,61$
e) Exames Sorológicos
$\mathrm{R} \$ 96,84$

Assim, o custo de uma bolsa de sangue, soma dos itens descritos, é de R\$ 153,57 , para bolsas colhidas dentro do Hemocentro. Vale ressaltar que os custos, nos 
procedimentos apontados, sempre são superiores aos valores pagos pelo Sistema Único de Saúde - SUS.

O custo da Rejeição Clínica do candidato à doação de sangue é o mesmo do item “a) Recepção e Triagem Clínica”, de R\$ 3,14.

O custo da Rejeição Sorológica é o mesmo do custo da bolsa de sangue, R\$ 153,57 . O valor de reembolso pelo SUS para o procedimento é de R $\$ 106,86$, mesmo para as perdas. A diferença é de $\mathrm{R} \$ 46,71$, que representam prejuízo real.

Apresentamos os valores, para os anos de 2001, 2002 e 2003, das perdas financeiras decorrentes de Rejeições Clínicas e Rejeições Sorológicas no Hemocentro de Botucatu, considerando a diferença de custo real e reembolso pelo SUS:

\section{Tabela VII - Distribuição anual de Rejeições Clínicas e Sorológicas com respectivos valores, em reais. Hemocentro de Botucatu}

\begin{tabular}{lcccccc}
\hline \hline \multirow{2}{*}{ Tipo de Rejeição } & \multicolumn{6}{c}{ ANO } \\
\cline { 2 - 7 } & \multicolumn{3}{c}{2001} & \multicolumn{2}{c}{2002} & \multicolumn{2}{c}{2003} \\
\cline { 2 - 7 } & $\mathrm{N}^{\circ}$ & Valor & N. & Valor & N. $^{\circ}$ & Valor $^{\circ}$ \\
\hline Rejeições Clínicas & 2.921 & $9.171,94$ & 2477 & $7.777,78$ & 2771 & $8.700,94$ \\
Rejeições Sorológicas & 864 & $40.357,44$ & 970 & $45.308,70$ & 824 & $38.489,04$ \\
\hline \hline
\end{tabular}

Fonte: Relatórios anuais de produção - Hemocentro

Os valores apresentados são absolutamente preocupantes, já que os custos das bolsas descartadas por Rejeição Sorológica aos cofres públicos chegaram a valores de $\mathrm{R} \$ 132.684,48$ em 2001, de R\$ $148.962,90$ no ano de 2002 e de R\$ $126.541,68$ em 2003, considerando que os custos dos procedimentos não tenham se alterado desde o período do estudo de ALVARADO ${ }^{8}$.

As implicações dos valores apresentados não podem ser outras senão as de evitar coletar sangue de doadores que serão rejeitados e terão suas bolsas descartadas. Há duas formas, em princípio, de alcançar este intento:

a) Capacitação dos doadores de sangue

Um conceito sobre doador capacitado para a doação de sangue é de doador que reúna, como capacitação, não só as informações necessárias para seu preparo para a doação de sangue e atitudes condizentes de autocuidado, mas que tenha consciência ao ponto em que a doação de sangue possa ser uma opção consciente que, de forma transcendente, deixe de ser um dever cidadão para ser um direito cidadão.

b) Investimentos na melhoria das triagens clínicas. 
Tabela VIII - Distribuição anual de Descartes por validadede Bolsas de Concetrados de Hemácias, com respectivos valores, em reais. Hemocentro de Botucatu.

\begin{tabular}{lcccccc}
\hline \multirow{2}{*}{ CUSTO } & \multicolumn{7}{c}{ ANO } \\
\cline { 2 - 7 } & \multicolumn{2}{c}{2001} & \multicolumn{2}{c}{2002} & \multicolumn{2}{c}{2003} \\
\cline { 2 - 7 } & $\mathrm{N}^{\circ}$ & Valor & N. ${ }^{\circ}$ & Valor & N. $^{\circ}$ & Valor $^{\circ}$ \\
\hline Custo total & 1.228 & $188.583,96$ & 955 & $146.659,35$ & 1.237 & $189.966,09$ \\
Prejuizo real & 1.228 & $57.359,88$ & 955 & $44.608,05$ & 1.237 & $57.780,27$ \\
\hline \hline
\end{tabular}

Fonte: Relatórios anuais de produção - Hemocentro

As perdas de bolsas de concentrados de hemácias, por validade, apresentam valores anuais de custos surpreendentemente altos, como mostra a Tabela VIII. Informações extra-oficiais, contudo, mostram que, mesmo com perdas, ainda são suspensas cirurgias ou mesmo transfusões clínicas nas enfermarias. Técnicos dos laboratórios de transfusão relatam que não há controle destas informações, mas que poderiam ser realizados levantamentos sobre as requisições de sangue para transfusão, onde, habitualmente, são anotadas as informações de não realização de transfusões eletivas por falta de concentrados de hemácias específicos nos estoques.

Estas informações reforçam a necessidade de cadastros atualizados $\mathrm{e}$ disponiveis que possam direcionar a captação de doadores com tipos sangüíneos específicos. Reforçam também a necessidade do contato mais estreito entre o médico hemoterapeuta, o profissional responsável pelo laboratório de componentes lábeis, que mantém o controle dos estoques, e a equipe de captação e coleta de sangue, para que haja a agilidade necessária impeditiva da suspensão de procedimentos por falta de sangue.

\subsection{Histórico recente das atividades de captação de doadores de sangue}

Nos últimos três anos, foram se caracterizando duas formas básicas de captação, com resultados não mensurados:

a) divulgação das necessidades de sangue através dos meios de comunicação;

b) captação ou capacitação dos doadores de sangue através de contato pessoal, "corpo a corpo".

As duas propostas apresentam resultados diferentes, a primeira causa pouco impacto em termos de número de coletas de bolsas de sangue, a segunda, muito mais eficaz, produz impacto efetivo em termos de quantidade de bolsas coletadas, relacionado com o contato direto com o doador de sangue. Contudo, considera-se que estas formas de captação sejam complementares. A primeira mantém o assunto sobre doação de sangue em voga, enquanto a segunda, mais efetiva, realmente traduz as expectativas de coleta de sangue.

Ao mesmo tempo, o modelo de coleta de sangue através de atividades de coletas externas, em outros municípios, manteve-se, assim como o fornecimento de carnês de solicitações de doações de sangue aos pacientes internados, com o intuito de reposição, característico do final da década de 1980 .

Algumas das atividades relacionadas com ao primeiro item foram instituídas e preservadas com a intencionalidade de tornarem-se eventos anuais: 
1) Dia Internacional do Doador de Sangue;

2) Arte para Salvar Vidas

3) Passeio Ciclístico "Viva a Vida"

\subsubsection{Atividades de captação e capacitação}

1) I Gincana pela Vida - envolvidas escolas públicas e particulares na arrecadação de leite e na captação de doadores de sangue. Resultou em 7.200 litros de leite, distribuídos a instituições de caridade e organizações de assistência e na captação de 340 doadores de sangue. Ocorreu entre 7 de agosto e 14 de setembro do ano de 2.000 .

2) Polícia Militar - realização de campanha com orientação aos policiais com o intuito de torná-los doadores voluntários de sangue, entre os dias 23 e 26 de novembro de 2001.

3) Centro de Diretores Lojistas (CDL) - divulgada a campanha, em parceria, "Um Ato de Amor dividido em 12 meses", iniciada em 20 de fevereiro de 2001.

4) Pastoral da Saúde da Igreja São Benedito - campanha para doação de sangue, em fevereiro de 2001.

5) Sindicato do Comércio Varejista de Botucatu (SINCOVAB) - parceria na campanha "Um Ato de Amor dividido em 12 meses", em fevereiro de 2001.

6) Lions Clube - campanha de esclarecimentos sobre Doações de Sangue, em março de 2001.

7) I Passeio Ciclístico "Viva a Vida", com recreação - arrecadação de alimentos e importante divulgação nos meios de comunicação locais, ocorreu no dia 20 de maio de 2001.

8) Hidroplás - empresa participou de evento com palestras e divulgação de informações sobre doações de sangue e capacitação dos funcionários para serem doadores. Ocorreu em 29 de abril de 2003

9) Arquidiocese de Botucatu - parceria na campanha "O Amor está no Sangue", entre janeiro e dezembro de 2001.

10) Feira Cultural da escola "La Salle" - campanha de esclarecimentos entre os alunos sobre doações de sangue e profissões correlacionadas, em 15 de setembro de 2001 .

11) Conselho de pastores das Igrejas Evangélicas (COPIEB) - campanha conjunta para doação de sangue ocorrida entre 05 de novembro de 2001 e 10 de maio de 2002. 
12) Missa em comemoração ao Dia Internacional do Doador de Sangue - realizada em 25 de novembro de 2001, com ampla divulgação da imprensa local.

13) Centro das Indústrias do Estado de São Paulo (CIESP) / Sindicato dos Trabalhadores das Indústrias Químicas e Farmacêuticas de Botucatu e Região parceria para incentivar a captação de doadores de sangue entre os funcionários das empresas afiliadas. Acordo adesivo assinado em 25 de maio de 2001.

14) Indústria Aeronáutica Neiva - campanha e palestras sobre doações de sangue para os funcionários da empresa, em 23 de abril de 2003.

15) Padre Marcelo Rossi - gravada fita de vídeo, estimulando as doações de sangue, e divulgada, em horário nobre, no nível regional, nas emissoras afiliada a TV Globo e pelo Sistema Brasileiro de Televisão (SBT), entre julho e setembro de 2002.

16) Daniel - Realizada e divulgada fita de vídeo com solicitação para que o público realizasse doações de sangue, em estadia do cantor na cidade, gravada pelo SBT no Hotel Chailot, no ano de 2002.

17) Eduardo Saçaki, piloto de motocross - anexada mensagem sobre doação de sangue em adesivo de divulgação com o logotipo do piloto e divulgação das doações de sangue no evento RECREANÇA (SESI - Rede Globo), em 2002.

18) Evento de motocross "Arena Cross" - Realizada e divulgada fita de vídeo sobre doação de sangue com os pilotos Edinho Nascimento, Eduardo Saçaki e Leandro Romagnoli, em junho de 2001, na Casa de Coleta de sangue, na cidade de Botucatu, gravada pelo SBT.

19) Campanha "Faça um Gol pela Vida" - parceria com a empresa Prodive com realização e distribuição de folhetos educativos e camisetas, durante os jogos da Copa do Mundo de futebol de 2002.

20) Empresa Tadeu Seguros - parceria com realização e distribuição de panfletos educativos sobre doações de sangue.

21) Câmara Municipal de Botucatu - aprovado projeto de lei que instituiu a "Semana do Doador de Sangue", em 29 de janeiro de 2002.

22) VI Olimpíada Infantil "Plínio Paganini" - divulgação sobre o tema da doação de sangue e execução de encenação teatral por alunos das escolas participantes, em 15 de outubro de 2002 .

23) Projeto "Doador do Futuro: o Doador Cidadão" - ocorrido entre $01^{\circ}$ de maio e 26 de setembro de 2002.

24) Aniversário de 20 anos do Hemocentro de Botucatu - Várias atividades comemorativas à data: Missa em homenagem ao Doador de Sangue; peça teatral 
"Um Toque de Amor", no Teatro Municipal de Botucatu; gincana de solidariedade "Vamos deixar o Hemocentro Positivo", no espaço cultural de Botucatu, atividades realizadas em novembro de 2002.

25) I concurso "Arte para Salvar Vidas" - concurso de desenho livre sobre o tema da doação de sangue. Teve o patrocínio e a colaboração da empresa Microlins e ocorreu entre o dia 22 de agosto e o dia 22 de setembro de 2002.

26) Faculdade de Tecnologia de Botucatu (FATEC) - realizada atividade de capacitação para doação de sangue e, posteriormente, coleta dos doadores, durante a recepção aos calouros, ocorrida em 13 de fevereiro de 2003.

27) "Termômetro do Doador de Sangue" - em parceria com o jornal "O Diário da Serra", iniciada divulgação diária de informações dos estoques de sangue do Hemocentro de Botucatu, iniciada em 27 de fevereiro de 2003.

28) "Dia Internacional da Mulher" - publicidade de agradecimento em jornais e rádios locais, incentivando a maior participação da mulher nas doações de sangue. Foram distribuídas rosas e exemplares de jornal, do dia, às mulheres que se predispuseram a doar sangue naquela data, 8 de março de 2003.

29) Tiro de Guerra de Botucatu - atividades de capacitação e de doação de sangue para os soldados, em 11 de março de 2003.

30) Primeiro Encontro Regional de Empresas pela Vida - em parceria com o Centro das Indústrias do Estado de São Paulo (CIESP), encontro onde foram expostas as necessidades de sangue dos hospitais da região, as atividades de captação e capacitação do Hemocentro de Botucatu e onde foram propostas formas de atuação e participação das empresas, colaboradoras na doação de sangue, como forma responsável de atuação junto à comunidade, ocorreu no dia 28 de março de 2003.

31) Escola Industrial - capacitação dos alunos para a doação de sangue e realização de coleta no próprio local, em 25 de abril de 2003.

32) Empresa LTM Indústria e Comércio de Chicotes Elétricos Ltda. - captação de doadores de sangue, ocorrida nos dias 18, 19, 20 e 21 de abril de 2003.

33) Grupo de Escoteiros "Padre Anchieta"- divulgação e capacitação para a doação de sangue, nos dias 27 e 28 de março de 2003.

34) Escola Municipal "Nair Amaral" - projeto "Doador do Futuro", inclusão de atividades curriculares sobre doação de sangue, entre os meses de abril e setembro de 2003.

35) Gold \& Silver - capacitação dos funcionários para doação e coleta de sangue ocorrida em 14 de abril de 2003. 
36) II Encontro de Captadores de Sangue - discussão sobre o melhor perfil do doador e sua capacitação para a doação no preparo para coletas externas. Definição de cronograma de coletas externas. Evento divulgado pela imprensa local, ocorrido em $01^{\circ}$ de julho de 2003.

37) II Concurso de desenho livre "Arte para Salvar Vidas" - em seu segundo ano, teve a participação de cerca de 1000 desenhos, teve o patrocínio da empresa Microlins e do jornal "O Diário da Serra". Culminou com evento no Cine Teatro Neli, com a entrega da premiação e apresentação de grupos das escolas em ensaios teatrais sobre o sangue e dança, realizada por grupo da terceira idade. Ocorreu entre 06 de agosto e 20 de outubro de 2003.

38) Extra-Eletro - a empresa, parceira do Hemocentro, propiciou coleta de sangue em suas dependências e patrocinou a divulgação, em 18 de setembro de 2003.

39) Centroflora - atividades de capacitação dos funcionários para a doação de sangue e assinatura de contrato de parceria entre sindicatos de funcionários, patronal e da diretoria da própria empresa para a doação regular de sangue. Eventos ocorridos em 20 de setembro de 2003.

40) Em parceria com o CDL, o SINCOVAB, a SABESP e a Secretaria municipal de Saúde, foram realizadas reuniões com o intuito de aumentar a captação de doadores de sangue. Foram propostos e realizados panfletos de divulgação de doações de sangue e de órgão que foram distribuídos anexados às contas de água no município de Botucatu, no mês de setembro de 2003. Foram realizadas atividades de telemarketing, entre 03 de outubro de 2003 e 27 de janeiro de 2004 .

41) II Passeio Ciclístico "Viva Vida" - patrocinado pelas empresas Extra-Eletro, Gold \& Silver e TIM, divulgou a doação de sangue e de órgãos, em 23 de novembro de 2003.

\subsubsection{Coletas Externas}

Não é realizado trabalho efetivo para capacitação de doadores de sangue na maioria dos municípios onde acontecem coletas externas habitualmente. A organização das coletas externas, em geral, é feita por enfermeiros dos postos de saúde ou por profissionais do serviço social dos municípios, não é atividade exclusiva e, às vezes, perde-se em meio a infinidade de tarefas concomitantes a serem realizadas.

Os folhetos explicativos não são efetivos, sendo comum, ainda hoje, doadores habituais apresentarem-se em jejum para a doação de sangue, ou mesmo terem ingerido quantidades de bebidas alcoólicas no dia precedente à doação.

Atividades de captação e capacitação de doadores de sangue, como as descritas no item anterior, não acontecem nos municípios onde se realizam coletas externas.

Foram organizados dois encontros regionais entre profissionais que organizam a captação de doadores de sangue nos municípios, com o intuito de troca de informações e relatos de experiências, nos anos de 2002 e 2003. Observou-se 
rotatividade dos trabalhadores da saúde nos municípios ou pouco tempo para realização de atividades correlacionadas. A conseqüência é variável, muitas vezes até, com excesso de doadores e sem o preparo adequado para a doação. Filas e tempo de espera aumentado, a espera avança até o período de jejum dos doadores, principalmente nos horários próximos ao almoço, nas coletas realizadas e iniciadas pela manhã.

\subsubsection{Doações por trabalhadores de empresas}

Um dos focos atuais no trabalho de capacitação de doadores de sangue vem sendo realizado nas empresas, principalmente nas indústrias, sob a premissa de que nelas estariam os indivíduos com melhores condições de saúde e autocuidado, principalmente para a manutenção da força de trabalho.

O encontro "I Encontro Regional de Empresas pela Vida" teve a participação de 11 empresas e a organização e o patrocínio do Centro das Indústrias do Estado de São Paulo - CIESP, como intuito de sensibilizar os empresários e os profissionais da área de recursos humanos para o envolvimento e comprometimento com a manutenção dos estoques de sangue do Hemocentro, ressaltando o compromisso social das empresas e a necessidade de responder e interagir com a comunidade.

No ano de 2003, conseguiu-se adesão de três empresas. Não houve avaliação sistemática dos dados e resultados, mas há indícios de que as rejeições sorológicas estejam em cerca de $2 \%$, valor abaixo dos quase $10 \%$ encontrados habitualmente.

\subsubsection{Doações por alunos universitários}

Em busca de doadores saudáveis, têm sido realizadas coletas externas em faculdades e universidades dos municípios da região, há alguns anos. Não há dados sistemáticos coletados para confirmar a melhor qualidade ou não, dos doadores de sangue universitários. Em geral, as coletas ocorrem no início do ano letivo e as informações para preparar os doadores não são sistematizadas, de maneira que não há uniformidade para que se considere que esse trabalho seja de capacitação dos candidatos à doação.

\subsubsection{Doações de reposição}

As doações de reposição ainda representam número significativo das doações ao Hemocentro de Botucatu, acontecem pela distribuição de "carnês", aos parentes próximos do doente internado no Hospital das Clínicas, contendo dez folhas, correspondendo à apresentação de dez doadores. Os "carnês" são distribuídos pelo setor de registros do Hospital das Clínicas, no ato da internação. Raramente são feitas recomendações aos familiares quanto ao preparo necessário à doação de sangue, mesmo havendo orientações básicas no verso de cada folha do "carnê".

Considera-se, ainda, que o doador de reposição, de alguma forma, seja coagido á doação, tanto pelo serviço de sangue, quanto pelos próprios parentes do doente internado. Esta obrigação pode ser fatal no comprometimento da qualidade do 
sangue, como mostram os resultados comparativos de doadores de reposição e doadores voluntários ${ }^{61,62,6}$.

\subsubsection{Considerações sobre marketing}

Observa-se grande atividade de relações públicas no Hemocentro de Botucatu. Procura-se, além de criar, divulgar qualquer evento que seja realizado, em jornais, rádio e televisão; com todos estes meios de comunicação, mantêm-se bom relacionamento e facilidades, além da sensibilidade sobre o tema.

A publicidade é conceituada por KOTLER ${ }^{91}$ como sendo um incentivo impessoal para aumentar a demanda por produto ou serviço pela colocação de notícias significativas sob a forma de apresentação favorável em jornal, rádio, televisão e teatro. A propaganda se caracteriza por forma paga de promoção de idéias, bens ou serviços, por um patrocinador identificado.

Muitos eventos são patrocinados por empresas também sensíveis às questões relacionadas à doação de sangue, que confeccionam folhetos e cartazes, alugam carros de som, fornecem lanches especiais aos doadores e garantem prêmios em concursos e sorteios realizados nos eventos.

Não é feita previsão orçamentária para que se possa realizar os trabalhos de divulgação e capacitação dos doadores de sangue, a propaganda. Os eventos quase sempre ocorrem em função de patrocínios externos.

O Hemocentro possui logotipo, mas não apresenta uma marca que represente o que realmente ele é e que facilite o relacionamento com o doador de sangue; relacionamento que pode ser construído com uma marca: um conjunto de promessas que implicam em confiança e em expectativas, definidas dentro da mente do doador de sangue, mas que precisam ser cumpridas e que ditam a qualidade percebida do serviço prestado.

Considerando-se que os doadores percebem a qualidade dos serviços do Hemocentro de acordo com expectativas geradas através da publicidade e da propaganda veiculada pelos diversos meios de comunicação e nos contatos "corpo-acorpo" com os possíveis candidatos à doação de sangue em palestras nas escolas e empresas, há necessidade de se estabelecer padrões de serviços definidos por estreito relacionamento entre os trabalhadores das atividades de relações públicas e de capacitação de doadores com àqueles da recepção, triagem e coleta de sangue. È o contrário da organização parcelar do trabalho, combatida por CAMPOS ${ }^{70}$. 


\subsection{Trabalho e Vínculo com o doador de sangue}

\subsubsection{O Trabalhador - Discurso do Sujeito Coletivo}

São apresentadas as perguntas, as respostas das idéias centrais identificadas e a força representada no discurso dos 13 trabalhadores entrevistados. Utilizou-se a notação "M", para profissionais com ocupação de nível médio, e "U", para aqueles com ocupação de nível universitário:

Você é uma pessoa que tem ou não um projeto para sua vida pessoal? fale um pouco sobre isso.

Construir familia, ter filhos, dar suporte, orientação e educação

O meu projeto é ter uma familia, construir uma família, ter filhos, eu penso nos meus filhos; porque a gente não é nada sem ter esta base. (M)

Meu projeto é poder educar os meus filhos com a maior qualidade possivel, não é? Dar o melhor para eles, a melhor escola, a melhor estrutura de formação, orientar melhor, junto com meus filhos, que eles descubram alguma coisa, também, que possa, futuramente, desenvolver, criar, gostar: um esporte, pintura... Essas coisas. Eu planejo a minha vida, para os meus filhos, para o meu marido. Meu projeto é esse: levar os filhos para frente, porque se eles estiverem bem, eu estarei bem, entendeu? (U) (F:92,3\%)

\section{Continuidade dos estudos}

Voltar a estudar e se tornar enfermeiro profissional, fazer uma faculdade e ter nível universitário para trabalhar no meu setor. Vou ter caminhos mais abertos. (M)

Entra na parte profissional, mas que é uma realização pessoal: estudar, continuar os estudos. Pretendo fazer mestrado, fazer curso de inglês, não é? Algum curso, assim, que venha contribuir para o trabalho. (U) (F:46,1\%)

\section{Aquisição de moradia, moradia própria e transporte}

Eu conseguir comprar minha casa própria, conseguir pagar a minha casa, que é muito dificil.(M)

Você quer ter, também, uma casa própria, vai lutar por sua casa própria, você quer ter um carro: você vai lutar para isso. (U) (F:38,5\%)

\section{Projetos de viagens}

Viajar com os meus filhos, poder mostrar a parte boa da vida. São sonhos... futuramente, poder ir para o exterior, não é?(U) (F:23,1\%)

\section{Estar bem empregado}

Ter um emprego bom, poder manter meus filhos.(M)

Poder ter um bom emprego.(U) (F:15,4\%) 


\section{Necessidade de paz}

A primeira coisa que eu almejo é paz. É, diante desta paz, que você vai buscar mais coisas...(U) (F:7,7\%)

\section{Caridade com o próximo}

Trabalhar com pessoas, trabalhar com vidas lá dentro da igreja, não é? vidas, vidas necessitadas... me doar um pouquinho mais para poder ajudar outras pessoas, também. (U) (F:7,7\%)

\section{Atividades de lazer}

Investir em áreas de lazer para me deixar mais calmo, menos estressado. $\dot{E}$ uma compensação do agito do dia a dia. Gosto muito de trabalhos manuais. (U) (F:7,7\%)

\section{Em relação a sua vida profissional, você tem um projeto para sua vida, ou não?}

\section{Continuidade dos estudos para evolução profissional}

Eu estou fazendo "auxiliar de enfermagem" e, se eu realmente gostar do que eu estou fazendo, eu vou investir, eu pretendo fazer uma faculdade de enfermagem, mesmo e tentar ingressar nessa área, na área de enfermagem. Ser formado, não é? Ter caminhos abertos para trabalhar no Hemocentro. Ai, eu vou batalhar mais quatro ou cinco anos, depois disso eu pretendo fazer ou aprimoramento ou uma pós... um mestrado, dentro da área da enfermagem e, se der para juntar faculdade de administração, eu pretendo fazer pós, mestrado em administração hospitalar. Aprender mais, subir mais na carreira, na área de enfermagem, mesmo. (M)

Eu quero crescer dentro da minha profissão, não é? Eu sinto que eu estou estagnada... faz cinco anos que eu estou aqui e eu estou parada mesmo. Não só ficar na prática do trabalho, começar a entender um pouco mais... começar a estudar mais, mesmo. Até começar a desenvolver trabalhos que, assim... poça ajudar tanto a gente como o hemocentro. Espero não demorar muito, não é? E, no final deste ano, defender uma tese, no futuro. Com estas informações que você obtém dentro do mestrado ou do doutorado e que você pode aplicar na tua vida profissional. Eu tenho anseio de crescer... de estar estudando, estar fazendo cursos, congressos, agora eu sinto que dá para fazer isto, e eu quero. (U) (F:69,2\%)

\section{Estagnação profissional}

Desde que eu entrei, estou na mesma função e não melhorei em nada. Que, também, não me ofereceram nada para eu melhorar. A gente não tem perspectiva, então a gente tem que estar sempre se mantendo atualizado em tudo que está acontecendo, que vai mudando. Não tenho porque estou quase aposentado.(M)

Poderia estar melhor se tivesse muitas coisas que está faltando... eu acho que o trabalho até sairia melhor se ouvissem mais a gente... às vezes ouvem, mas 
não... vamos dizer assim: ouvem, mas não resolvem. É isso. Então... isso também acaba desanimando, no trabalho. O tempo que a gente ficou aqui, a gente ficou muito parada, parada no sentido, assim... da gente ir buscar outras informações, aprender várias coisas. (U) (F:38,5\%)

\section{Desenvolvimento cientifico}

Desenvolver projetos, pesquisas. (M)

Desenvolvendo projetos. (U) (F:15,4\%)

\section{Identificação com o trabalho de captação}

Na área de captação, a gente tem que ser ousado, certo? e, é um trabalho que eu me identifico muito: um, pelo conhecimento das pessoas, um, pela facilidade da minha... do meu contato, certo?(M)

O que mais me move, no projeto profissional, é poder ter a chance de criar, é diferente quando você trabalha com o doador, quando você faz alguma coisa... quando você trabalha diretamente com as pessoas, mudando comportamento ou ajudando emergir um comportamento que está meio que apagado ou a comunidade... (U) (F:15,4\%)

\section{Atualização de conhecimentos e adaptação às mudanças}

Constantemente a gente está em mudanças, não é? Então a gente tem que estar se adaptando a essas mudanças e são mudanças que exigem novas perspectivas... eu sempre busco ver qual é o motivo que está começando a falhar... sempre busco ver uma nova, um novo incentivo e sempre buscando propostas de melhoria, sempre acompanhando o mercado de trabalho, não é? Então, a gente sempre tem que estar, nesse sentido, se atualizando não adianta grandes idealizações, de repente a gente acaba se frustrando com algumas coisas, não é? Eu tenho sempre em meta, assim... estar sempre atualizando, lendo constantemente, estudando constantemente, para me atualizar dentro de tudo que está acontecendo. (U) (F:15,4\%)

\section{Dificuldades para estudar}

Fazer faculdade à noite, já sei o que é isso, já foi quatro anos isso... agora... vamos ver se a verba, agora, dá para fazer. (M) (F:7,7\%)

\section{Organização e metas para os laboratórios}

Também, a por metas dentro de todos os laboratórios aqui e em organizar, não é? organizar melhor... (U) (F:7,7\%)

\section{Estímulo aos profissionais das áreas}

Tem que se estimular às pessoas para que elas vão para frente dentro de cada área dela, não é?(U) (F:7,7\%) 


\section{Melhoria de relacionamento}

A gente tem meta de tentar melhorar esse relacionamento no dia-a-dia, tem que estar gerenciando estas coisas instantaneamente, de hora em hora, de dia em dia, entendeu? (U) (F:7,7\%)

\section{Entre os seus colegas do Hemocentro você percebe um projeto comum de trabalho? fale sobre isso.}

\section{Individualismo no trabalho}

Não, ts... ts... nem um pouco! Não tem nem um coleguismo dentro do hemocentro, porque um... vive o seu momento, ali, pensa na pessoa dele, mais a parte só de fazer o serviço deles e só. Nada mais que isso. Outros trabalham, mais, assim: não têm planos de ficar ali mesmo, de construir uma coisa junto. Pouca gente se interessa pela captação de sangue. Quanto a parte da coleta, é pouco o contato, assim... de conversar a respeito disso, de saber e de identificar, entre eles, se tem um plano de trabalho para isso, entende? (M)

Eu acho que, ainda, nós estamos vivendo muito individualismo. Passamos por um periodo ruim, onde o ambiente de trabalho não era legal, os colegas, estressados... acho que isso individualizou mais ainda a equipe. As pessoas trabalham e não vejo, assim... colaboração para que os doadores possam estar voltando, eu acho isso: que não existe essa integração no nosso trabalho, cada um faz o seu... isso me frustra muito, não é? As pessoas estão muito preocupadas... não me excluo disso, não. Muito preocupados consigo mesmos, com o seu trabalho ali dentro, não vejo que tenha um interesse comum de desenvolver um trabalho, estar fazendo alguma coisa... percebo muito pessoas isoladas, não grupos. Não estamos conseguindo trabalhar, assim, paralelamente; percebo que as pessoas estão trabalhando, assim: muito pessoalmente, elas não estão se entregando em conjunto, não é? São extremamente individualistas, não é? (U) (F:61,5\%)

\section{Estabilização e crescimento profissional}

Uns, eu percebo, assim, que eles têm planos de se estabilizar lá dentro do hemocentro mesmo, crescer lá dentro. Alguns falam que vai estudar. Gostaria de ver estas pessoas como enfermeiros aqui dentro! (M)

Eu vejo, mesmo nas áreas mais simples, você vê que, dentro daquela área dele, o individuo, ele está querendo aprimorar, o fazer melhor, sabe? Estar evoluindo. É a própria meta do ser humano, estar evoluindo, evoluindo. (U) (F:23,1\%)

\section{Situações que dificultam objetivo comum de trabalho, comprometem a dignidade do trabalho}

Na verdade, não é? ela ganha como flebo, trabalha como se fosse enfermeira. Um fez o "auxiliar" agora, mas não é auxiliar de enfermagem aqui, registrado no 
hemocentro. Aqui, ele é auxiliar de laboratório... Outro, que está sendo contratado, mas que também não é funcionário, não é? Está prestando um serviço. Às vezes essa outra pessoa não está no mesmo ritmo que você, não tem aquela.. é uma responsabilidade nas suas costas: se não fizer, vai faltar! Se faltar, vai cobrar quem? "Ah, eu sou funcionário, eu não estou aqui para isso", se acontecer um acidente de trabalho com ele, ele não vai ter a mesma cobertura que a gente, que é funcionário, não é? e ele está trabalhando do mesmo jeito que a gente. Você vai receber certo no final do mês, e eu que nem sei se vou receber e tenho que trabalhar', não é? (M)

Funcionários que forem abordados de uma forma digna têm chance de dar certo, de termos uma equipe, mas tem muito que ser feito para chegar lá. Eu percebo, às vezes, que tem muita disputa, aqui dentro. E, são poucas pessoas, o que me deixa muito chateado... têm muita disputa aqui dentro, muita rixa, entre um e outro, isso que eu acho que atrapalha um pouco um trabalho mais harmonioso. (U) (F:23,1\%)

\section{Sobrevivência, salário, como motivos principais de trabalho}

Você vai receber certo no final do mês, e eu que nem sei se vou receber $e$ tenho que trabalhar, não é? (M)

Eu sinto, assim, que as pessoas vêm trabalhar para receber o salário, no final do mês... no meu ponto de vista: um grupo, unido, é lógico com o objetivo, não é? talvez, maior, de sobrevivência do que de realização profissional. (U) (F:23,1\%)

\section{Ausência de projeto de trabalho}

Não vejo ninguém comentar: vamos fazer um negócio diferente para o doador? não vejo! não tem ninguém, não vejo ninguém apresentar projeto de trabalho aqui. A gente não tem um plano de trabalho, hoje, um plano de trabalho para poder desenvolver, no papel, e resolver o dia-a-dia. (M) (F:15,4\%)

\section{Conhecimento dos sentimentos, objetivos pessoais integrados aos do hemocentro como maneira de somar as forças individuais}

É importante saber, também, o que as pessoas estão sentindo e, entre nós mesmos, tentar nos adaptar àquilo que é importante para a gente, qual é o nosso objetivo dentro do hemocentro, dentro da coleta, não é? e eu sinto que o pessoal está bem desintegrado nesse sentido, então? Tem! Tem como a gente poder pensar alguma coisa para somar essa força! (U) (F:7,7\%) 
Agora, eu queria que você falasse um pouco sobre os doadores. Eles são pessoas que têm alguma coisa em comum, ou não?

\section{Características sociais percebidas (F:61,5\%)}

\section{a) Doadores pobres ou menos favorecidos são os mais freqüentes}

A maioria deles é de classe baixa, a maioria analfabeta, humilde, eles são umas pessoas simples, simples até demais, que a gente, no olhar deles a gente já vê a feição da classe pobre. Homens, não é? e... é isso: a maioria deles, principalmente aos sábados.

Ás vezes, a gente nem consegue furar o dedo do doador de tão calejada que é a mão, que a pessoa trabalha na roça, mesmo.

São aqueles doadores de reposição, que sempre acabam vindo assim... vêm de longe, não é? mas, assim: por amizade, família... mas são pessoas que também que... acabam perdendo o seu dia de serviço, pessoas e que "graças a Deus tem a UNESP para cuidar do meu paciente... meu parente".

E mais fácil a gente... você... ter um resultado positivo... com as pessoas... as pessoas de baixa renda, entendeu? para trazer, para poder o trabalho surtir efeito, certo?

Eles não têm uma situação econômica tão boa que possa fazer um almoço, comer um lanche, por conta própria baixa, são doadores que vêm porque precisa doar para alguém, não é?

São pessoas parecidas... na profissão, em termos de classe social, são pessoas semelhantes. Dificil é alguém que se destaque ou diferente desse meio. (F:61,5\%)

\section{b) Doadores ricos são raros e impõe doaçães aos pobres}

A gente não vê gente classe média para alta, quase, doando sangue. Só poucos, os de nivel mais alto, que a gente consegue trazer, concorda?

Uma vez ou outra que você vê dono de empresa parando a fábrica $e$ mandando funcionário vir aqui. Quer dizer... ele não veio doar sangue, ele mandou o pessoal lá em baixo (subalterno) no lugar dele vir doar sangue. Então, ele não tem necessidade... para ele, ele tem um pessoal que pode cobrir a parte social. (F:23,1\%)

\section{Motivação percebida para a doação de sangue (F:46,1\%)}

\section{a) Ajuda, solidariedade}

É uma coisa comum, em todos os doadores, é de ser reconhecido que ele está ajudando a salvar vidas, ajudar, mesmo, vêm para colaborar. Eu acho que a solidariedade, ser solidário, está presente; mas, são muito poucos os que eu vejo, assim, que vêm de coração, sabe "ah, eu vim por vir, porque eu gosto de ajudar" É lógico que tem, não é? voluntários; mas, no meu ponto de vista, são a minoria. (F:30,8\%) 


\section{b) Busca de atestado médico}

Têm aqueles que vêm só para pegar o atestado, não vêm para doar com a intenção de ajudar o próximo: têm a intenção de pegar o atestado e só isso, mesmo ( $F: 15,4 \%)$

\section{c) Reposição de sangue ao Hospital das Clínicas}

Percebo, assim, que muitos deles vêm porque tem uma afinidade muito grande com esses... com essas pessoas para quem eles estão vindo doar, não é? vem porque tem alguém que está doente aí. (F:15,4\%)

\section{d) Motivação para doar depende de estímulo}

Todas essas pessoas que a gente procura, só dependem, mesmo, de estímulo, de você conseguir estimular esta população a ser doadores... (F:7,7\%)

\section{e) Doação de sangue em busca de bem estar e felicidade}

Eles ficam felizes quando doam, eu acho que isso é o ponto, porque a pessoa, o ser humano, acho que tem que buscar a felicidade, porque a felicidade é nada mais do que momentos em que você pode se doar de uma forma gratuita, de uma forma que você sabe que está fazendo o bem para o próximo. É um momento de felicidade. (F:7,7\%)

\section{Atitudes esperadas de amor, carinho e bom tratamento entre os trabalhadores para com o doador de sangue.}

Eu peço para eles ter amor e carinho nas pessoas e um procurar ajudar o outro, porque a gente tá... todos nós estamos no mesmo barco. A gente tinha que tratar o doador igual a gente trata o filho, a esposa da gente, o familiar da gente... está muito a desejar o atendimento do doador, eu acho. O lanche melhorou muito, eu acho que a parte do lanche melhorou, tem uma copeira excelente, acho que está, assim: está contribuindo com a parte dela, entendeu? Eu penso que o doador é uma coisa importante, é o combustível do hemocentro. Então, eu acho que ele tem que ser o cara mais tratado do mundo. (M) (F:15,4\%)

\section{Necessidades expressas pelo doador de sangue ao trabalhador (F:15,4\%)}

\section{a) Agilidade no atendimento}

A única coisa que eles pedem para nós, que somos flebotomistas, eles pedem para que a doação de sangue não demorar muito, a triagem ser mais rápida... a reclamação deles é nesse ponto, que eles vêm aqui com... como posso dizer... de livre e espontânea vontade. (M) (F:7,7\%) 


\section{b) Dificuldades em encontrar ou trazer doadores de reposição}

"Ai, mas eu tenho que trazer dez, moça. Como eu vou fazer para conseguir estes dez, se eles não pode faltar do serviço?" é às vezes, não é? (M) (F:7,7\%)

Recepção com informações inadequadas com demora no atendimento, periodos de ausência do profissional triador e limitação da oferta do lanche

Não é uma recepção adequada, a gente não tem muitas informações na recepção, entendeu? E, chega ali a recepção, às vezes, está sozinha, não tem ninguém para informar, entendeu? Ele fica lá meia hora, quarenta minutos $e$ ninguém vai lá dar uma satisfação, entendeu? Acontece isso! Tem deficiência na triagem clínica, eu acho, também que, às vezes, não tem alguém para triar, no momento, entendeu? A gente está muito relaxado na sala, eu acho que tem que melhorar. (M)

Eu acho errado, porque se você veio, quer dizer: você veio para doar, não é? Você até sabe que vai comer um lanche depois e, chega ali, as pessoas... não que... algumas pessoas ai, da chefia acabaram... barrando: se não doa, não come. (U) (F:15,4\%)

\section{Necessidade de trabalho com doadores mais conscientes}

A gente teria que trabalhar com outro tipo de doadores, eu acho que está faltando um pouco mais de conscientização para a doação de sangue. (U) (F:7,7\%)

Como é que é o seu relacionamento com estes doadores? fale um pouco sobre isso.

\section{Como o profissional percebe seu relacionamento com os doadores (F:100,0\%)}

\section{a) Bom relacionamento com os doadores}

Ah, é fantástico! É ótimo. A recepção é muito grande. Eu me dou muito bem com os doadores, eu tento conversar, puxar assunto lá dentro, pro pessoal não ficar tão nervosa, a gente brinca com eles, a gente dá risada com eles... para mim, eu... acredito que sim. Eu gosto de trabalhar com doadores e não tenho, assim, dificuldades em me relacionar com eles, não. (F:53,8\%)

\section{b) Tratamento educado e profissional com relação aos doadores}

O meu relacionamento, em primeiro lugar, é de respeito com eles, não é? respeito de ética. Eu procuro tratá-los da melhor maneira possivel, eu procuro ser clara, ser gentil, eu tento ser profissional ao máximo, entendeu?

Você pode chegar, cumprimentar, perguntar se está tudo bem, se está bem de saúde, antes de começar aquele monte de perguntas, que são aquelas perguntas, não é? que se o indivíduo não tiver uma estrutura, assim, ele pode se sentir até ofendido. Então, você tem que fazer uma apresentação da doação, da importância do paciente, 
da importância para ele estar respondendo verdadeiramente, não é? cumprimentar o doador... eu falo "por gentileza, o senhor estica o braço? a gente vai fazer assepsia..." essa empatia é muito importante: o doador não pode ver você como uma pessoa que sabe muito além dele e, que ele, não tem condição de compreender, porque a maioria dos doadores são pessoas carentes, de baixa renda. Sempre procuro conversar para ver se foi bem atendido e agradeço as pessoas pela doação. Eu acho isso dai muito importante, assim, a respeito de recepção aos doadores, essa atenção... mas, esse relacionamento, não acaba tendo muito contato com eles, porque, como o papel do captador é de sair captando, não é? eu acho que a pessoa, também, se sente muito bem. (F:53,8\%)

\section{c) Tratamento semelhante a todos os doadores, tratados como iguais}

Não têm diferença para mim, não: não tem branco, não tem preto, não tem rico, não tem pobre. São todos iguais. (F:15,4\%)

\section{d) Necessidade de limite entre doador/trabalhador}

Mas, ao mesmo tempo, não me expor muito, porque, muitas vezes eles levam para o outro lado. (F:7,7\%)

\section{e) Capacidade de contornar situações de dificuldade de relacionamento doador/trabalhador}

Quando aparecem aqueles doadores mais ruins que, às vezes, não é? ou implica com fila ou implica com alguma coisa, eu acho assim.. eu consigo desvencilhar bem quando acontece algum problema. (F:7,7\%)

\section{f) Vinculo com o doador de sangue}

Eu dou, muito, abertura para o doador se sentir à vontade, eu sinto que o doador se sente à vontade quando ele está falando comigo, não é? quando eles terminam uma doação eu vou lá, eu brinco, eu agradeço, eu, de uma maneira ou de outra, sempre estou convidando para voltar. Então, eu dou muita importância, eu valorizo, eu respeito demais o doador independente de qual a condição de ele estar vindo, não é? mas eu sempre digo que ele é muito importante, não é? eu gosto de frisar isso, eu não vejo diferença entre as pessoas. (F:7,7\%)

\section{Comportamentos desejáveis e indesejáveis do trabalhador (F:46,1\%)}

\section{a) Tratar bem o doador com o intuito de que retorne para nova doação e traga amigos}

Por mais que a pessoa vem com cinco pedras na mão, se você tratar ela com educação, ela derruba as cinco pedras da mão. Mas, no mínimo, tratar com educação e paciência, porque eles estão aqui de graça, não é? ver se está tudo em ordem, ver se foi bem atendido... então, acho que essa preocupação tem que ser, assim, no geral, principalmente para quem está ali, atendendo o doador. Às vezes, 
você não está a fim de ficar sorrindo para o doador, mas tratar com educação e, se a pessoa dá abertura, conversar, brincar, ver quando a pessoa também não gosta de brincar, mantém ali, sempre à distância. Acho que ele tem que ser uma pessoa respeitada, com direitos e com os deveres. E, tratar do doador, sair com o doador, levar o doador até o lanche, agradecer ele e pedir que ele volte, entendeu? fazer uma nova captação, entendeu? fazer com que o cara volte e traga um amigo. Tem que tentar tratar eles o melhor que puder, para eles voltar sempre, porque não é fácil achar doador de sangue. $O$ mais importante: acolher muito bem; toda vez que você convoca, você estar presente para acolher "que bom! você veio", na hora do doador somos todos seres humanos. (F:38,5\%)

\section{b) Conversas não pertinentes à atividade de trabalho próximas ao doador}

Falo para eles isso aí: vamos ver como é que está... não fica conversando uma coisa que não pode conversar perto dos doador... eu procuro explicar para eles antes, porque... não fala isso, não olha, entendeu? não se vê, isso; então... cada um na sua posição, tentando ajudar um ao outro. (M) (F:23,1\%)

\section{c) Posicionamento do trabalhador de não cobrar atitudes ou atividades de seus colegas}

Eu não posso cobrar também... eu sou um auxiliar. A gente não fala porque é colega de trabalho, então... tem que ver tudo isso! (M) (F:15,4\%)

\section{d) Não trazer problemas pessoais para o trabalho}

Às vezes a gente vem meio nervoso, quer descontar no doador, certo? tem o dia que até pode derrubar pasta de dente na camisa e ficar meio bravo; traz as coisas da casa aqui para dentro do hemocentro... inclusive eu até falei para as pessoas que trabalha com nós ali que, trazer problema de fora para dentro, aqui, vai tratar mal o doador, o doador não vai voltar. (M) (F:15,4\%)

\section{e) Necessidade de transcender o bom atendimento e ter amor na atividade com o doador}

Não pode ser extremamente profissional a ponto de não deixar o humano aparecer, não pode. Tem que ter emoção, tem que ter... eu diria para você que tem que ter amor no que você faz. (U) (F:7,7\%)

\section{Informações relatadas pelos trabalhadores repassadas ao doador}

É.. informar eles do que vai ser feito, que vai fazer um cadastro, depois vai fazer um teste no dedo, explicar, mais ou menos, o que vai acontecer dentro da doação, explico o que eu estou fazendo com o doador, entendeu? Coleto, explico o que eu estou coletando, o que é isso que eu estou coletando, o que é aquilo às vezes, o doador, é a primeira vez que está doando... "agora eu vou picar... agora eu vou limpar seu dedo" ou "agora vou limpar seu braço", passar as orientações bem devagar e bem detalhadas depois da doação... porque às vezes a pessoa... "ai, nem 
ouvi direito, ah, não falou nada". Dispenso o doador olhando para a cara do doador, porque eu acho que isso é importante, falar "olha, o senhor não pode beber, fumar, fazer esforço fisico nenhum, tá?". A gente sempre está pedindo para voltar: gostou da primeira vez, pode voltar dali três meses, dali quatro meses... (M) (F:23,1\%)

\section{Sentimentos do doador percebidos pelos trabalhadores}

Ali quando só o doador, que eles, de costas, começa conversar o grupinho, deixa o doador para trás: o doador fica constrangido: "nossa, nem deu atenção para mim?" já falei um monte de vezes para a chefia, lá... sabe, se não der atenção para eles, eles ficam constrangidos, mesmo. (M)

$E$ ele tem que sentir que existe humanidade, não pode sentir frieza na instituição, embora, ela seja séria no trabalho. Já teve caso de algum doador reclamar de algum funcionário... eu nunca vi reclamações assim, constantes, não é? eventualmente, raramente... teve épocas que tinha mais. (U) (F:23,1\%)

\section{Organização de agenda}

Se nós agendasse 50 pessoas por dia, não teria esse amontoado de pessoas brigando, às vezes tá discutindo, brigando aí, porque é um horário de trabalho, o outro quer horário de outra coisa... levar o filho na escola, se a gente poderia agrupar ai e agendar todo o mundo. (M) (F:7,7\%)

\subsubsection{Entrevistas com psicólogos}

Abordagem psicológica aconteceu entre os anos de 1998 e 2000, com o intuito de realizar levantamento das dificuldades de relacionamento interpessoal de todo o Hemocentro, com destaque aos diversos laboratórios e aos profissionais da sala de coleta de sangue dos doadores.

Contratou-se profissional psicólogo com formação psicodinâmica que tinha, como objetivo de trabalho:

a) Promover o entendimento, entre os profissionais, do papel e da importância do Hemocentro, dentro do Hospital das Clínicas;

b) Obter diminuição do erro humano nos diversos procedimentos técnicos;

c) Evitar ou diminuir perdas de materiais;

Com relação aos profissionais que mantinham contato direto com doadores de sangue, como os da recepção, da triagem clínica, da sala de coleta de sangue e da sala de hidratação e lanche para o doador:

d) promover a melhoria da disponibilidade e da receptividade destes profissionais para atender adequadamente os doadores.

Vale ressaltar que a especificidade dos serviços prestados pelo Hemocentro, de fornecimento de componentes sangüineos, em geral para pacientes em risco de 
vida iminente ou com patologias graves, para os quais o tempo é fator determinante para a sobrevivência e, sendo as doações de caráter voluntário, como prevê a atual legislação brasileira ${ }^{7,82}$, tudo isso gera expectativa e ansiedade aos trabalhadores, como conseqüência: haverá sangue suficiente amanhã? Será necessária a suspensão de cirurgias por falta de sangue?

Estas questões, por si, justificam a necessidade da contratação do profissional para acompanhamento psicológico dos profissionais do Hemocentro, destacadas as áreas que precisam fornecer respostas imediatas, como no laboratório de transfusão e na captação e coleta de sangue. Estas justificativas são reiteradas nas atuais entrevistas com os trabalhadores, em seus discursos e no Discurso do Sujeito Coletivo sobre a percepção de projetos comuns de trabalho:

Passamos por um periodo ruim, onde o ambiente de trabalho não era legal, os colegas, estressados...

Observam-se situações de estresse, inter-relacionadas com individualismo e falta de projetos comuns de trabalho conseqüente, ao menos em parte.

O profissional utilizou-se de técnicas de dinâmicas de grupo ou mesmo de psicodramatizações. As técnicas possibilitaram o levantamento de problemas e o pensamento conjunto de soluções.

Houve muita resistência ao trabalho, segundo o profissional, justificada pela característica de "complexidade do funcionário público", ressaltando a "facilidade destes em não assumir compromissos", também pela incompatibilidade entre as soluções, para os problemas levantados, entre os trabalhadores e a chefia, a impossibilidade de "pensar junto". Esta situação "arrebentava o trabalho" com grupo em acompanhamento dos trabalhadores, impedindo suas próprias soluções e permitindo a adoção de comportamento de ignorância, não real, dos problemas anteriormente levantados.

Destacou o número significativo de pessoas jovens, com noção adequada do compromisso do serviço nos grupos. Também observou o "medo da consciência do papel do Hemocentro" relacionado aos casos graves e à "rotina alucinante" dos profissionais que desencadeariam defesa rudimentar de negação.

O trabalho, sob pressão e risco, não permite espaços para extravasamento.

Dramatizações realizadas com troca de papéis, "brincar de chefe", auxiliaram no entendimento das dificuldades deste em conduzir o Hemocentro.

As conclusões sobre o trabalho realizado neste período apontam para:

a) Necessidade de que haja propósito verdadeiro em solucionar problemas, por parte das chefias administrativas;

b) Identificação de grupos em "disputas por territórios";

c) Problemas de comunicação, comunicação identificada principalmente como "fofocas no ouvido do chefe" e no alívio das tensões que acontece em bate-papos nos corredores e no "fumódromo";

d) Sentimento de culpa dos funcionários pelas condições de trabalho (material e de pessoal suficientes), com implicações de transferência de responsabilidades; 
e) Reuniões para esclarecimento de problemas ficam em aberto, sem o retorno para fechamento dos assuntos.

Em março de 2003, por iniciativa do Diretor Técnico do Hemocentro, foi contratado novo profissional psicólogo com o intuito de melhorar as relações de trabalho entre os profissionais, inicialmente com os que, formal ou informalmente, exerciam atividade de comando, depois com outro grupo composto por técnicos de diversas áreas do Hemocentro.

A linha de psicológica adotada, desta vez transpessoal, baseou-se na Escola da Dinâmica Energética do Psiquismo, que trabalha diretamente com a consciência, pela compreensão de seus estados e padrões, nas experiências individuais e coletivas da humanidade.

Metodologicamente, a Escola tem como objeto o cuidar do Ser, a busca da integração e da unidade de si mesmo ${ }^{79}$.

A alternativa, com vistas às experiências dificeis anteriores relacionadas a situações de trabalho, foi de optar-se por "não buscar o conflito, mas buscar a flauta afinada". A essência desta linha de trabalho foi descrita, pelo psicólogo terapeuta, com essa metáfora: o ser humano é uma flauta com suas três partes: física, mental e emocional. Sua proposta de trabalho foi de que a flauta desafinada, que cada um de nós é, possa ser afinada, em um processo objetivo de busca. Busca da presença, da unidade: "ficar inteiro" dentro de si mesmo, em linguagem mais técnica, ajuda em ressignificar e a integrar novas possibilidades de expressão de comportamento e de atitudes, na manifestação da consciência.

A iniciativa concretizou-se em encontros semanais, em número de doze, em cada grupo, abordados os aspectos: físico, emocional, mental ou intelectual.

As técnicas utilizadas envolveram atividades de respiração, meditação, imaginação ativa, contato com a sombra interior e programação neurolingüística.

\section{a) Respiração}

A respiração consciente é a base que sustenta a Plena Atenção.

Sugere-se a respiração abdominal intercostal, como técnica, focalizando-a na parte mais baixa dos pulmões:

"Respirar nas costas expande a percepção consciente pela ativação do fluxo de energia na medula, relaxando os anéis energéticos onde se encontram os bloqueios. Permite ao indivíduo sair da energia de ataque ou defesa, característica da área frontal. Significa tornar-se mais harmônico e poder, assim, conectar-se com o silêncio interno, verdadeiro espaço de meditação. Este tipo de respiração permite o alívio da tensão e do enfrentamento com o externo, facilitando a interiorização e o contato com sensações e sentimentos. A ênfase da Escola está na necessidade do terapeuta se colocar em ressonância com os níveis transpessoais, a fím de ajudar o cliente a vivenciar o seu processo seja de transmutação, de transformação ou de transcendência" 79 .

\section{b) Meditação}

A meditação, concomitante e auxiliada à respiração, é outra técnica utilizada nos trabalhos. GOSWAMI ${ }^{80}$ nos diz que aquela é o único método de criatividade 
interna no aprendizado de dar atenção, ser desapegado, identificar "com certa precisão" o que acontece em nossa vida diária para romper com a existência no nível do ego. No estado de consciência meditativa há predomínio de ondas cerebrais de baixa freqüência do tipo alfa e ondas teta, nas medições eletroencefalográficas. Estas últimas, relacionadas à experiência criativa.

\section{c) Imaginação Ativa}

Pode ser considerada uma forma de meditação, em que se aproveita uma situação que surge espontaneamente, como uma situação de sonho inconclusiva ou um estado de espírito momentaneamente modificado, com absoluta liberdade, depois de se esvaziar a consciência do ego. O intuito é de obter-se exclusivamente a verdade a respeito de nós mesmos ${ }^{88}$.

\section{d) Sombra}

Segundo SILVEIRA ${ }^{77}$, citando Carl Gustav Jung, sombra é uma "espessa massa de componentes diversos, aglomerando pequenas fraquezas, aspectos imaturos ou inferiores, complexos reprimidos, até forças verdadeiramente maléficas", mas também podem ser discernidas características valiosas, não manifestadas por condições externas desfavoráveis.

\section{e) Programação Neuro-lingüística}

Lida com sensações registradas em nosso corpo, com estratégias mentais das pessoas em situações bem sucedidas, utilizando-se estes padrões em outras situações, quando podem ser transferidos. Conjunto de atitudes de comunicação com o propósito de atuar de forma eficiente em situações diversas, realiza-se através da lingüística, código do pensamento e seu modo de expressão, de forma programada ${ }^{89}$.

Em princípio, a proposta de abordagem mostrou-se de muito interesse, pois apresentava o bem estar pessoal como objetivo do processo terapêutico, independentemente dos problemas específicos relacionados ao trabalho, os interrelacionamentos pessoais, ambos secundários e resolvidos como conseqüência desse bem estar pessoal a ser alcançado e, não simplesmente alcançado, mas compartilhado coletivamente, não por meio individual e isolado.

As dificuldades começaram a surgir quando parte dos integrantes do grupo expuseram ou demonstraram conflitos, contradições com seus conceitos e crenças religiosas, talvez por entenderem que os procedimentos desta proposta de abordagem ser "mística", talvez, também, "não científica" dentro dos moldes cartesianos deterministas vigentes na universidade e dentro do Hemocentro, da realidade materialista onde os aspecto principal de sua produção científica é quantitativo. Como aceitar benefícios ao relacionamento interpessoal e mesmo pessoal quando estes benefícios advêm de "coisas intangíveis" 78 como técnicas de respiração, mentalizações, mantras e músicas orientais que parecem induzir-nos a estados semelhantes à hipnose coletiva?

A resposta do psicólogo terapeuta foi de que estes artifícios não estariam ligados a outro significado que não auxiliar na "afinação da flauta" e que sua utilização estaria relacionada muito mais ou exclusivamente com a criatividade do 
processo terapêutico que desenvolvia, criatividade a ser estimulada para resolução dos acertos internos pessoais e do grupo.

Eu diria, como resposta à pergunta, que isto é possivel, mas demanda a aceitação de um novo paradigma, defendido por cientistas físicos, filósofos, psicólogos, entre outros, que propõe, os princípios da incerteza contra o determinismo causal, a não-localidade contra a localidade (física quântica), a unicidade e as visões integrais e holísticas contra a dualidade - sujeito/objeto, céu/terra, certo/errado, entre outros aspectos.

$\mathrm{Na}$ autobiografia de Joseph Jaworski ${ }^{78}$ descreveu-se sua "jornada do herói" e a criação do curso do Amereican Leadership Forum, em 1983, depois de abandonar sua carreira de advogado, de absoluto sucesso, nos Estados Unidos. Uma das etapas fundamentais do curso era uma experiência de natureza inóspita, de seis dias, que incluía atividade de sobrevivência de 24 horas. O cenário para a atividade era ao ar livre prevendo escaladas em montanhas e, o intuito, era de que cada um superasse seus medos, apoiando-se no grupo e, podendo "escutar, falar e aprender com maior eficiência", construindo confiança verdadeira entre os participantes. Este livro foi prefaciado por Peter Senge e espelha muitas das idéias deste autor.

Arrisco-me a dizer que efeitos semelhantes talvez tenham sido obtidos nas atividades realizadas com o grupo de líderes do Hemocentro, nas atividades de respiração e de meditação dirigidas: busca interior, autoconfiança e confiança no grupo. Arrisco-me, também, a dizer que experiências de "alinhamento" ocorreram neste grupo de líderes do Hemocentro. "Alinhamento" 78 foi termo usado por Senge para descrever acontecimentos onde pessoas de um determinado grupo começam a funcionar como um todo único, como nos casos de "conjuntos extraordinários de jazz e times campeões de basquete"; ainda, com os grupos do American Leadership Forum, em suas experiências inóspitas.

Peter Senge também considera que novas lideranças devam ter seus alicerces em formas de pensar diferentes da "visão mecânico-newtoniana do século XVI a respeito do universo", que ainda movimenta nossos pensamentos, e, admite estarem ocorrendo mudanças históricas na visão ocidental científico-materialista do mundo.

O auxílio no trabalho para a edição do livro citado de Jaworski e as conversas com o físico David Bohm que o direcionaram no período de conclusão de seu livro "A Quinta Disciplina" 73, destacando o compromisso com a verdade, dentro da disciplina de Domínio Pessoal e o diálogo como sinônimo de fluxo de significados, fundamental para a aprendizagem em equipe.

Retornando, o psicólogo terapeuta observou diferença significativa entre os dois grupos; considerou que houve maior comprometimento no grupo de líderes que no grupo de técnicos, mas observou vínculo em ambos. Vínculo como "caminho para o coração". Este último grupo teve interferência, antes que chegassem à metade dos encontros, pelo falecimento acidental do Diretor Técnico, em junho de 2003, que significou a quebra do vínculo maior. Em sua opinião, ele fazia a sustentação dos grupos, por apresentar-se, como líder, entusiasmado, claro e motivado. Com seu contrato desfeito, sem pagamento, o psicólogo terapeuta manteve seu compromisso e finalizou o trabalho com o grupo de técnicos, nos encontros programados. 


\subsubsection{Domínio Pessoal}

O conceito de Domínio Pessoal que se apresenta é o de se alcançar nível especial de proficiência, de comprometimento com seu próprio aprendizado ao longo da vida, de esclarecer e aprofundar nossa visão pessoal, de concentrar energias e desenvolver a paciência e de ver a realidade objetivamente.

O Domínio Pessoal deve ser visto como contínuo esclarecimento do que é importante para nós, através da identificação de problemas ou de dificuldades que possam nos dispersar ou desviar do caminho dos nossos objetivos, da visão da realidade atual, mais clara: saber onde nos encontramos no momento, possibilitam a motivação e a criatividade para o pleno desenvolvimento desta disciplina.

Qual o limite entre os objetivos pessoais e os objetivos profissionais?

As questões escolhidas, apresentadas na metodologia, que suscitaram a construção do Discurso do Sujeito Coletivo dos trabalhadores, tiveram a intenção de separar as idéias para facilitar a análise posterior, mas, talvez a importância dos objetivos profissional dentro dos objetivos pessoais ocupasse maior proporção.

Tanto nos grupos de nível médio quanto nos de nível universitário, destaca-se a preocupação com a família, a educação dos filhos, principalmente o vínculo estreito de existência e inter-relação:

A gente não é nada sem ter esta base... porque se eles estiverem bem, eu estarei bem. (F:92,3\%)

A subsistência não superada e dificil, entre os dois níveis, com a manutenção de moradia e do transporte, surge no discurso:

...vai lutar por sua casa própria, você quer ter um carro: você vai lutar para isso... que é muito dificil. (F:38,5\%)

$\mathrm{O}$ projeto de vida pessoal, entre os profissionais de nível médio, não ultrapassa questões relacionadas à família e à subsistência. Entre os de nivel universitário, ainda que de maneira pouco objetiva ou não estruturada, dispostas sob a forma de desejos, tais projetos são superados na intenção de alcançar paz, viagens, lazer e a realização de caridade no auxílio a pessoas necessitadas. de vida:

A continuidade dos estudos surgiu em ambos os níveis como projeto pessoal

Voltar a estudar... fazer uma faculdade e ter nivel universitário... continuar os estudo. Pretendo fazer mestrado,... Algum curso que venha contribuir para o trabalho. (F:46,\%) mais força:

Como projeto profissional, a idéia central de continuidade dos estudos ganha

Vou batalhar mais quatro ou cinco anos, depois disso eu pretendo fazer ou aprimoramento ou uma pós... um mestrado, dentro da área da enfermagem e, se der para juntar faculdade de administração, eu pretendo fazer pós, mestrado em 
administração hospitalar. Aprender mais, subir mais na carreira, na área de enfermagem, mesmo. (F:69,2\%)

O trabalho, dentro da perspectiva de projeto pessoal, não apareceu, senão por ter um bom emprego (F:15,4\%), mesmo assim, para poder manter meus filhos.

Dos preceitos fundamentais da disciplina do Domínio Pessoal, destaca-se a clareza da realidade atual, demonstrada no Discurso do Sujeito Coletivo dos trabalhadores, sobre o conhecimento apresentado relacionado às características dos doadores e mesmo dos problemas que resultam em individualismo e do comportamento frente aos doadores de sangue e entre si próprios.

A visão, o esclarecimento do que cada trabalhador quer para si, contudo, está clara com relação à família e todos os eventos que a circundam, mas a visão sobre o trabalho mostra-se enevoada, ofuscada pela idéia de continuidade nos estudos. Esta idéia, de importante peso no discurso, demonstra o que SENGE ${ }^{73}$ considera como visão reduzida, "concentrar-se nos meios e não nos resultados". singulares:

A identificação com o trabalho de captação e citada em apenas dois discursos

Na área de captação, a gente tem que ser ousado, certo? e, é um trabalho que eu me identifico muito: um, pelo conhecimento das pessoas, um, pela facilidade da minha... do meu contato, certo?(M)

O que mais me move, no projeto profissional, é poder ter a chance de criar, é diferente quando você trabalha com o doador, quando você faz alguma coisa... quando você trabalha diretamente com as pessoas, mudando comportamento ou ajudando emergir um comportamento que está meio que apagado ou a comunidade... (U) $(\mathbf{F}: \mathbf{1 5}, \mathbf{4} \%)$

Talvez, a importante sensação de estagnação no trabalho (F:38,5\%) seja decorrente à falta de clareza da visão pessoal do trabalho.

A questão específica sobre projeto de vida profissional tem respostas, tanto para os trabalhadores de nível médio quanto para os de nível universitário, relacionadas com estagnação profissional:

Estou na mesma função e não melhorei em nada. A gente não tem perspectiva. O tempo que a gente ficou aqui, a gente ficou muito parada, $\mathbf{( F : 3 8 , 5 \% )}$

A estagnação profissional tem resposta reativa de que:

Então a gente tem que estar sempre se mantendo atualizado em tudo que está acontecendo, que vai mudando... da gente ir buscar outras informações e aprender várias coisas. $(\mathbf{F}: \mathbf{1 5 , 4 )}$

A continuidade dos estudos para evolução profissional aparece com força no Discurso do Sujeito Coletivo, não só para alcançar diploma universitário, mas além, por cursos de pós-graduação: 
ser formado, não é? Aí eu vou batalhar mais quatro ou cinco anos, depois disso pretendo fazer aprimoramento ou uma pós... um mestrado,... aprender mais, subir na carreira. (F:69,2\%)

Entre os trabalhadores com nível universitário, a expressão do Discurso do Sujeito Coletivo é a mesma:

Eu tenho anseio de crescer... estar estudando, estar fazendo cursos, congressos, agora eu sinto que dá para fazer isso e eu quero.

O sentido de importância da continuidade dos estudos aparece na expressão:

Ter caminhos mais abertos para trabalhar no Hemocentro e com estas informações que você obtém dentro do mestrado ou do doutorado e que você pode aplicar na tua vida profissional. Até começar a desenvolver trabalhos que, assim... poça ajudar tanto a gente como o Hemocentro.

A erosão da visão, obstáculo no desenvolvimento da disciplina do Domínio Pessoal, aparece no Discurso do Sujeito Coletivo sob a idéia central de atualização e adaptação às mudanças:

Constantemente a gente está em mudanças, não é? Então a gente tem que estar se adaptando a essas mudanças e são mudanças que exigem novas perspectivas... eu sempre busco ver qual é o motivo que está começando a falhar... sempre busco ver uma nova, um novo incentivo e sempre buscando propostas de melhoria, sempre acompanhando o mercado de trabalho, não é? Então, a gente sempre tem que estar, nesse sentido, se atualizando não adianta grandes idealizações, de repente a gente acaba se frustrando com algumas coisas, não é? Eu tenho sempre em meta, assim... estar sempre atualizando, lendo constantemente, estudando constantemente, para me atualizar dentro de tudo que está acontecendo. (U) (F:15,4\%)

A expressão de frustração pode ser traduzida como medo de um possível fracasso, manipulação de conflitos estruturais, o que também é forma de redução da visão.

\subsubsection{Objetivos Comuns}

A ausência de objetivos comuns de trabalho teve força modesta no Discurso do Sujeito coletivo dos trabalhadores:

Não vejo ninguém comentar: vamos fazer um negócio diferente para o doador? não vejo! não tem ninguém, não vejo ninguém apresentar projeto de trabalho aqui. A gente não tem um plano de trabalho, hoje, um plano de trabalho para poder desenvolver, no papel, e resolver o dia-a-dia. (M) (F:15,4\%) 
Apesar de esta força negativa do discurso ser modesta, ela é ampliada pela idéia central de individualismo no trabalho:

Não tem nem um coleguismo dentro do hemocentro, porque um... vive o seu momento, ali, pensa na pessoa dele, mais a parte só de fazer o serviço deles e só. Nada mais que isso. Outros trabalham, mais, assim: não têm planos de ficar ali mesmo, de construir uma coisa junto. Pouca gente se interessa pela captação de sangue. (M)

Eu acho que, ainda, nós estamos vivendo muito individualismo. Passamos por um periodo ruim, onde o ambiente de trabalho não era legal, os colegas, estressados... acho que isso individualizou mais ainda a equipe. As pessoas trabalham e não vejo, assim... colaboração para que os doadores possam estar voltando, eu acho isso: que não existe essa integração no nosso trabalho, cada um faz o seu... isso me frustra muito, não é? As pessoas estão muito preocupadas... não me excluo disso, não. Muito preocupados consigo mesmos, com o seu trabalho ali dentro, não vejo que tenha um interesse comum de desenvolver um trabalho, estar fazendo alguma coisa... percebo muito pessoas isoladas, não grupos. São extremamente individualistas, não é?(U) (F:61,5\%)

Não só ampliada, como embasada por problemas estruturais percebidos pelos trabalhadores que afetam ou impedem a existência de projetos comuns de trabalho:

Na verdade, não é? ela ganha como flebo, trabalha como se fosse enfermeira. Um fez o "auxiliar" agora, mas não é auxiliar de enfermagem aqui, registrado no hemocentro. Aqui, ele é auxiliar de laboratório... Outro, que está sendo contratado, mas que também não é funcionário, não é? Está prestando um serviço. Às vezes essa outra pessoa não está no mesmo ritmo que você, não tem aquela.. é uma responsabilidade nas suas costas: se não fizer, vai faltar! Se faltar, vai cobrar quem? "Ah, eu sou funcionário, eu não estou aqui para isso", se acontecer um acidente de trabalho com ele, ele não vai ter a mesma cobertura que a gente, que é funcionário, não é? e ele está trabalhando do mesmo jeito que a gente. Você vai receber certo no final do mês, e eu que nem sei se vou receber e tenho que trabalhar', não é? (M)

Funcionários que forem abordados de uma forma digna têm chance de dar certo, de termos uma equipe, mas tem muito que ser feito para chegar lá. Eu percebo, às vezes, que tem muita disputa, aqui dentro. E, são poucas pessoas, o que me deixa muito chateado... têm muita disputa aqui dentro, muita rixa, entre um e outro, isso que eu acho que atrapalha um pouco um trabalho mais harmonioso. (U) (F:23,1\%)

Não foi feita qualquer referência à missão do Hemocentro, nos discursos dos trabalhadores, sugerindo que esta não seja compartilhada por eles.

A missão do Hemocentro de Botucatu, afixada em diversos locais, é de "Prestar assistência hemoterápica e hematológica com qualidade, formando e atualizando recursos humanos, com a finalidade de fornecer hemocomponentes e hemoderivados com padrão exigido pelas normas de vigilância sanitária, garantindo a segurança do procedimento hemoterápico desejado dentro de uma visão de saúde pública". 


\subsubsection{Modelos Mentais}

Identificamos um Modelo Mental dos mais importantes nos profissionais de captação e coleta: tem-se como verdadeira a possibilidade de "subir na carreira" e de reconhecimento profissional através da continuidade dos estudos, porém a estrutura, o organograma existente já mostrado e a ausência de plano de cargos e salários - não considerando a Avaliação de Desempenho Profissional praticada atualmente - são absolutamente incompatíveis com esse Modelo Mental, não correspondem à realidade, pois não permitem ascensão imediata na carreira, senão por concurso interno para funcionários autárquicos, que não ocorrerá até que haja modificação política que determine reestruturar o subquadro de funcionários e autorizar a reposição de aposentados. Muito menos tem a motivação por aumento de salário: atualmente, títulos de especialização, mestrado ou doutorado, não implicam em aumentos.

Outro Modelo Mental que se apresenta com intensidade entre os trabalhadores das áreas de coleta e captação de doadores de sangue é o de que nos meses com feriados prolongados, destacando-se o de dezembro com os feriados de natal e de ano novo, há aumentos no consumo de sangue o que justificaria aumentos na captação de doadores nestes períodos. Este Modelo Mental é refutado pelos dados de coleta e de consumo de sangue, ilustrados nos materiais e métodos. O consumo de bolsas de concentrado de hemácias é praticamente constante durante os meses do ano, enquanto as coletas de bolsas sofrem flutuações. Os resultados são a perda por validade de bolsas que se relacionam aos períodos imediatos aos meses de aumento de coletas.

A clareza da realidade exige dados administrativos de produção, relativamente fáceis de serem obtidos e que, expostos de maneira sistemática, podem auxiliar em desfazer este Modelo Mental que representa aumento dos custos, em todos os níveis, por perdas de bolsas por prazo de validade expirado.

\subsubsection{Arquétipos}

A ocorrência de um problema subjacente que demande dificuldade de abordagem ou por sua solução depreender grande esforço, gera sintomas e, comumente, as pessoas transferem soluções, muitas vezes paliativas que, às vezes, aliviam os sintomas, mas que pioram as dificuldades no decorrer do tempo e fazendo com que se perca capacidade para soluções eficazes e duradouras.

\section{Transferência de Responsabilidade}

A transferência de responsabilidade é um dos arquétipos de comportamento que transparece na captação dos doadores de sangue. As bolsas contendo concentrado de hemácias duram até 35 dias, sendo assim, pode-se considerar que tal periodo seja necessário para renovação dos estoques deste tipo de bolsa.

As atividades apontadas na captação, descritas anteriormente, onde se ressalta o peso dos doadores de reposição (53,7\% das doações de sangue em 2003$)$ e dos doadores em primeira doação (47,5\% das doações de sangue em 2003) têm importância fundamental na manutenção destes estoques, o que indica fragilidade do 
sistema de captação praticado, já que não se consegue reter doadores voluntários para doações de repetição, como se deseja.

Com as situações de baixa nos estoques a responsabilidade é passada ao captador de doadores que recorre aos meios de comunicação locais, acertos com empresas para doação imediata de seus funcionários. Com o tempo, a banalização das propagandas e dos apelos nas reportagens é inevitável, o que acaba gerando maior ansiedade no captador e na equipe, apelos mais veementes nos meios de comunicação, desânimo geral pelos resultados modestos.

A transferência de responsabilidade apenas para o captador de doadores de sangue se caracteriza no Discurso do Sujeito Coletivo pelo individualismo no trabalho e ausência de projetos comuns percebidos pelos trabalhadores, já detalhados anteriormente.

\section{Esquema I}

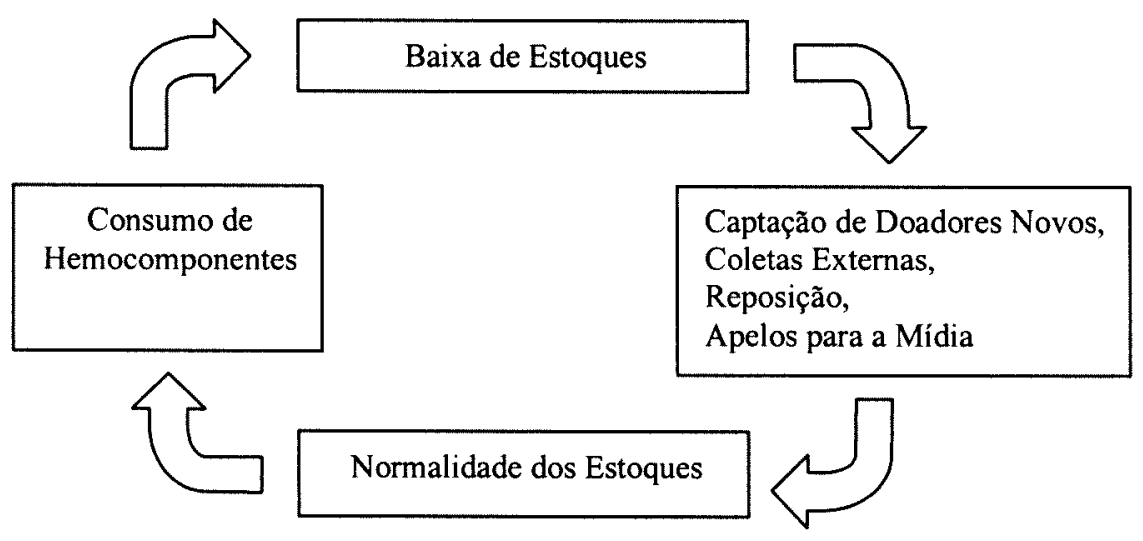

A solução paliativa ou sintomática de buscar os meios de comunicação de forma apelativa e procurar doadores em pequenas comunidades como empresas, grupos religiosos e escolas acabam sendo, praticamente, as únicas alternativas quando há baixas importantes nos estoques de bolsas de sangue, em particular, de concentrado de hemácias. Este tipo de solução pode gerar picos de doações de sangue imediatamente após os períodos de crise, determinando também a possibilidade de perdas de bolsas pelo prazo de validade. Há períodos característicos e sazonais, já descritos no item onde se tratou dos Modelos Mentais, onde se receia haver baixas nos estoques de sangue, como nas festas de final de ano e carnaval, o que implica na escolha de determinados locais para Coletas Externas em datas previamente fixadas, os dados, no entanto não mantêm correspondência com o pensamento dos trabalhadores, de que há maior consumo nos periodos sazonais referidos, pois, como já visto.

\section{Processo de equilibrio com defasagem}

O Esquema I mostra outro arquétipo, intimamente ligado com o anterior, de transferência de responsabilidade, que é o de processo de equilíbrio com defasagem, 
mostra ações corretivas, às vezes em excesso, que acabam por obrigar o descarte de bolsas, perdidas por validade.

O enfraquecimento da situação arquetípica do processo de equilíbrio com defasagem passa por diminuir as soluções heróicas de convencimento dos indivíduos através da divulgação de situações de fatalidade pela falta de doações de sangue e pelos apelos de solidariedade para evitar catástrofes, reforçando-se gradativamente a captação de doadores voluntários espontâneos. Para tanto, as funções de captação devem ser entendidas e compartilhadas por toda a equipe que mantém contato direto com os doadores de sangue. Possível solução é apresentada no Esquema III, no item 5.6.8, utilizando o pensamento sistêmico.

\subsubsection{Aprendizagem em Equipe}

Não há possibilidade, no momento atual, de que se desenvolva o aprendizado em equipe. A demonstração apresenta-se no discurso do Sujeito Coletivo dos trabalhadores nas idéias centrais de estagnação profissional e individualismo no trabalho com a ausência de projetos comuns entre estes mesmos trabalhadores; ainda, a ausência de espaços formais de comunicação, talvez a principal ferramenta para o desenvolvimento desta maneira de aprendizado.

\subsubsection{Utilizando o Pensamento Sistêmico}

Apresenta-se a seguir esquemas, baseados no pensamento sistêmico, de questões que se apresentaram nas entrevistas com os trabalhadores, ressaltadas no Discurso do Sujeito Coletivo e relações de estrutura e processos.

O sistema original, que ocorre hoje, é apresentado no ciclo superior do Esquema II. São considerados o Modelo Mental de continuidade dos estudos e todas as questões estruturais e de processos, além das observações dos psicólogos terapeutas e, que envolve os trabalhadores do Hemocentro diretamente relacionados à captação e coleta de sangue de doadores.

Ainda no Esquema II, o ciclo alternativo, abaixo, é apresentado como solução definitiva, mesmo que não se abandone de imediato o ciclo superior. Aponta-se a defasagem de tempo, que pode ser demorada, mas não deve ser esquecida pelos líderes e chefias do Hemocentro. Serve como alavancagem para o desenvolvimento do Domínio Pessoal e do Vínculo com o doador de sangue. A conseqüência, em longo prazo, é que se receba maior número de doadores capacitados e freqüentes, trabalhadores com objetivos mais definidos, visões mais claras da realidade e mais felizes.

Sugere-se que a disciplina do Domínio Pessoal não seja imposta através de reciclagens e treinamentos; mas, com exemplos, incentivando o diálogo, como fluxo de significados, e o compromisso com a verdade. 


\section{Esquema II}

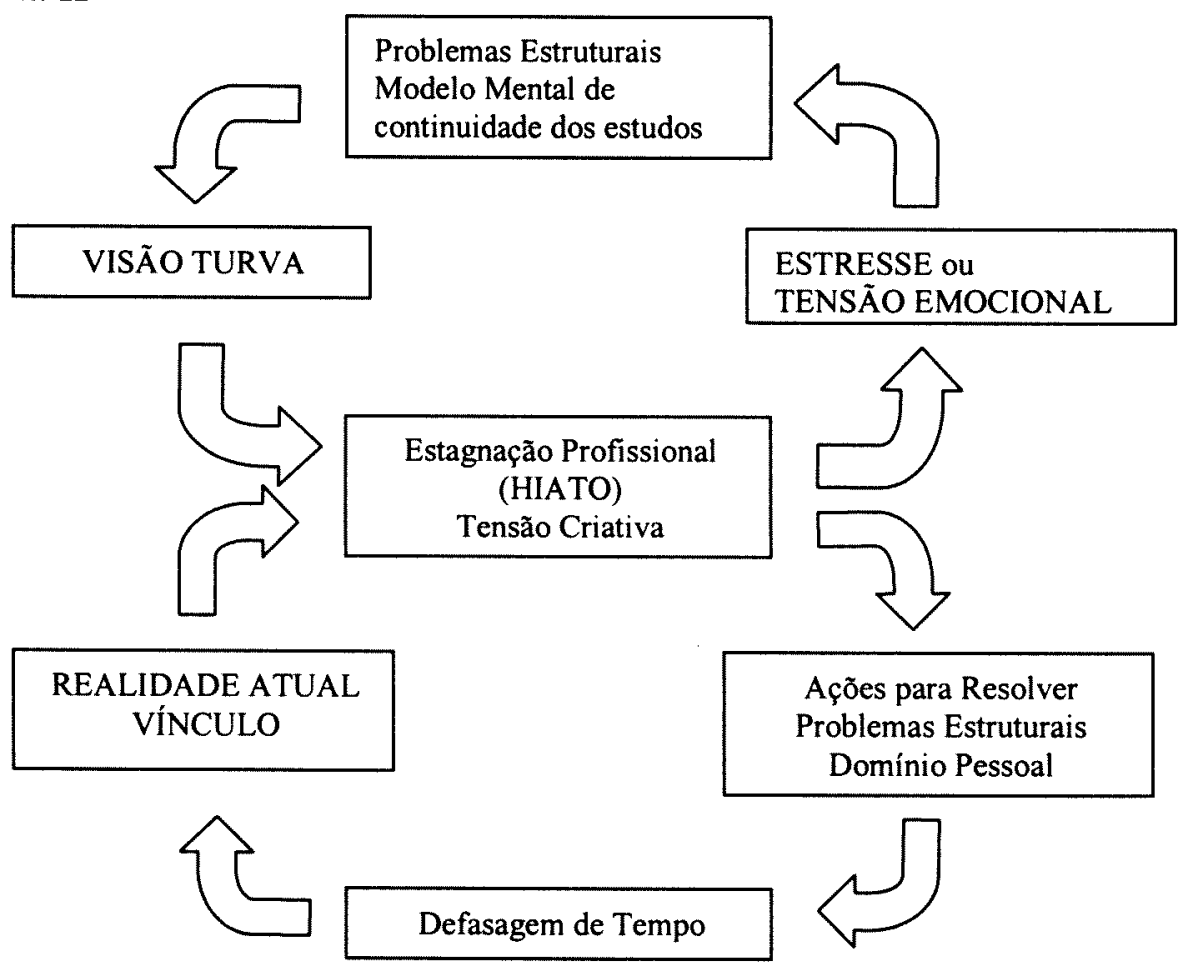

Identificou-se o arquétipo processo de equilíbrio com defasagem, já apresentado, para o qual se apresenta solução sistêmica possível, no Esquema III.

\section{Esquema III}

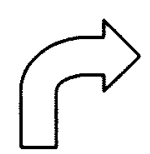

Consumo de Hemocomponentes

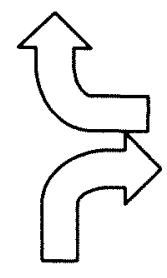

Adequação do Consumo de Bolsas de Sangue
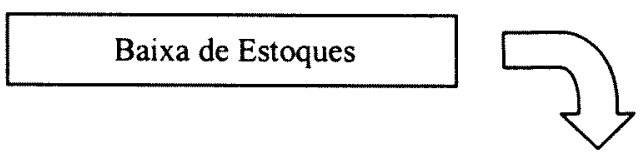

Captação de Doadores Novos, Coletas Externas,

Reposição,

Apelos para a Mídia

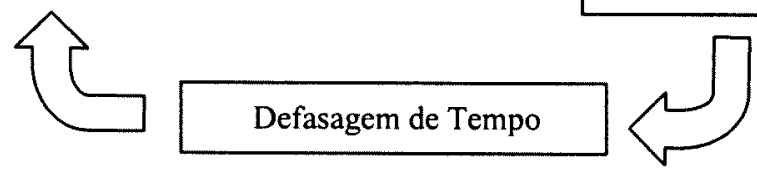


A solução paliativa, apresentada na forma de arquétipo de comportamento, pode ser solucionada estimulando-se o aumento do Vínculo entre o trabalhador e o doador de sangue e de maneira a indicar ou questionar sobre a indicação transfusional através de revisão de tal indicação, por especialista.

$O$ Vínculo pode ser estabelecido com a capacitação dos doadores de sangue, o que envolve a necessidade de conhecer bem o doador que se apresenta, identificar suas necessidades e responder a estas necessidades.

No Esquema IV é mostrado outro pensamento sistêmico que envolve os modos de comunicações atuais, arquetípicos, que podem ser considerados normóticos, segundo a concepção de CREMA ${ }^{90}$. O autor destaca a normose da fofoca, "a pior e mais terrível forma de controle social, porque todos se vigiam. Quem se desvia dos trilhos da normose sujeita-se à tirania da fofoca", em um jogo despótico de autoridades introjetadas que mantém os indivíduos "nos trilhos da normose social".

Um sinal de que as pessoas carecem de informações honestas para a realização de seu trabalho é, de acordo com as idéias de WHEATLEY ${ }^{93}$, a proliferação de rumores e fofocas. Diz que, quando não se tem acesso a informações verdadeiras, criam-se informações. Afirma que "as pessoas sabem que a informação é vital para a sua capacidade de fazer um bom trabalho" e que "sabem o quanto estão carentes de informação".

O ciclo superior reforça a situação atual de falta de comunicação em espaços formais dentro do Hemocentro, que aparece na idéia central de estagnação profissional do Discurso do Sujeito Coletivo dos trabalhadores. O modo de comunicação é subjacente, sob a forma de fofocas e diz-que-me-diz, como ressaltou em suas conclusões o psicólogo terapeuta, fato que incentiva o individualismo, que se apresenta com força de $61,5 \%$ no discurso dos entrevistados, posicionamento que reforça a permanência das deficiências estruturais e impede a visão e a existência de objetivos comuns compartilhados.

A abertura de espaços formais para comunicação, mostrada no ciclo inferior, pode funcionar como alavancagem para romper o ciclo superior, propiciando reconhecimento mais apurado da realidade atual, maneira de incentivo à disciplina do Domínio Pessoal, principalmente se houver Diálogo e Compromisso com a Verdade. A criação de espaço formal para comunicação, até seu funcionamento efetivo, leva tempo, paciência e perseverança para alcançar resultados. Os ruídos das fofocas e "diz-que-me-diz" podem ser ampliados como manifestação de resistência a mudanças, correndo riscos de desmotivação do grupo pela falta imediata de resultados.

DEJOURS ${ }^{86}$ ressalta que a desigualdade na divisão do trabalho, que pode ser caracterizada pelos diversos vínculos de emprego para funções ou tarefas semelhantes, traz revolta e frustração, pode alimentar falsas esperanças de promoções e desloca o debate sobre o trabalho para questões pessoais, favorecendo a manipulação psicológica e a rivalidade, também a "constituição de sistema de relações de suspeita e espionagem". Dificil é a não participação no sistema ${ }^{86}$. 


\section{Esquema IV}

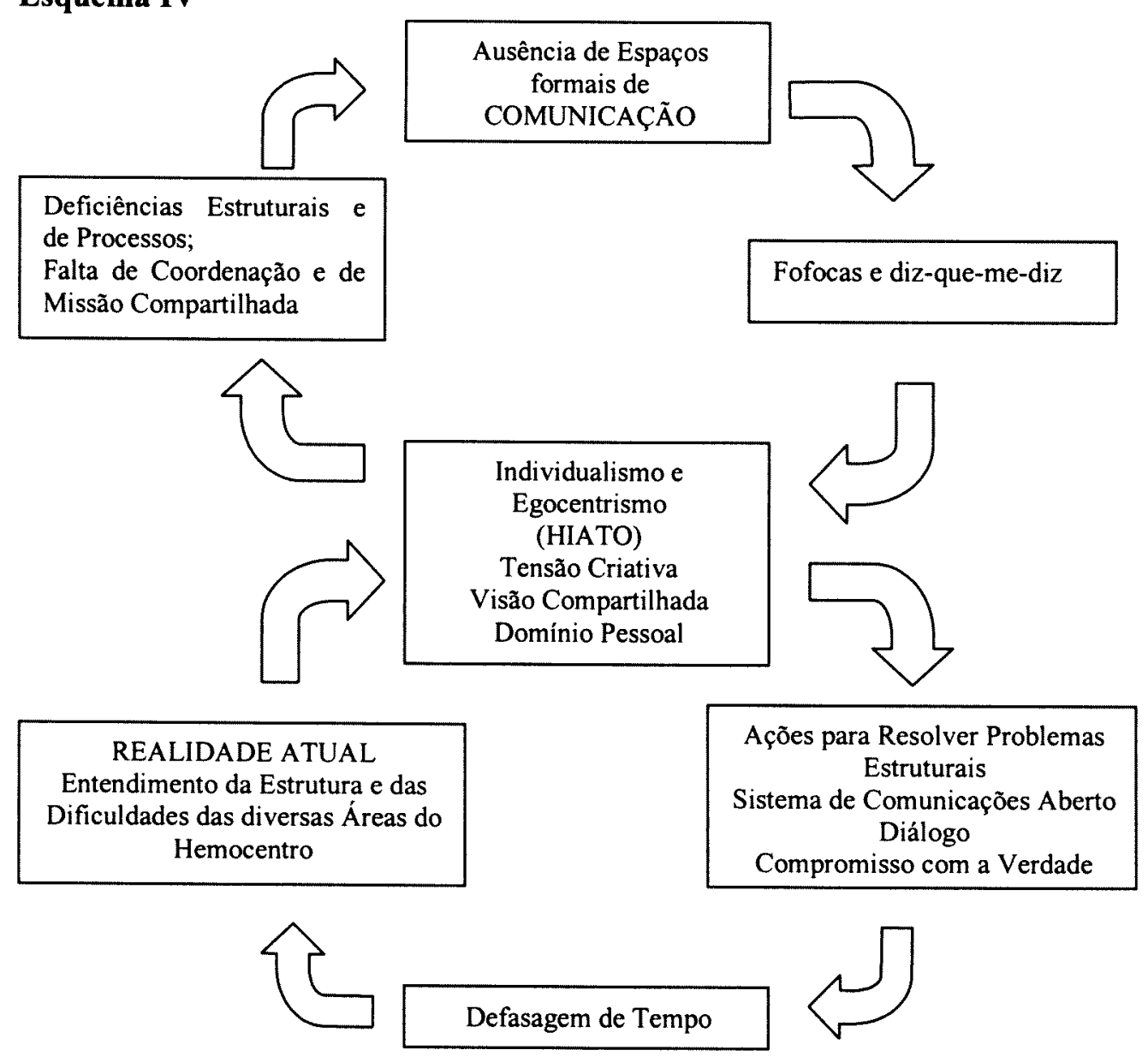

WHEATLEY ${ }^{93}$ diz que a solidão se difundiu não apenas na ciência, mas em toda a cultura ocidental, ressaltando que se levou o individualismo à sua expressão mais acabada, na América, "cada um de nós protegendo suas próprias fronteiras, afirmando seus direitos, criando um universo".As idéias da autora são compatíveis com a situação apresentada. Não pode existir aprendizado em equipe enquanto essas fronteiras não forem rompidas.

A autora sugere que a abordagem sobre o individualismo deva incluir melhoria da capacidade de ouvir, de dialogar e de respeitar à singularidade de cada um, com o intuito de obter a flexibilidade individual necessária ao trabalho em equipe, o que só tem condições de ocorrer mediante a abertura de espaços de comunicação. 


\section{CONCLUSÕES}

\subsection{Qualidade dos dados}

O atual sistema de informações do Hemocentro não apresenta qualquer facilidade na obtenção de dados gerenciais ou, como neste caso, dados que subsidiem trabalhos científicos, propósito de qualquer serviço que esteja sob o controle ou comando de uma universidade, uma faculdade de medicina pública.

Há necessidade de revisão imediata do sistema de cadastros e de recuperação dos dados armazenados desde o ano de 1991, quando foi elaborado o primeiro sistema. Atualmente, estar-se-ia com banco de dados de mais de uma década, quando hoje se pode contar com dados de relatórios consolidados impressos.

As indicações que se apresentam, para iniciar a resolução dos problemas encontrados são:

a.) Verificação da existência dos dados referentes ao período entre 1991 e 2000 , quando foi instalado o atual sistema, pela empresa SBS Consultores;

b.) Verificação da compatibilidade entre as estruturas das tabelas dos dois sistemas (o antigo e o atual);

c.) Verificação de "backup": garantir que, se houver perdas ou falhas no sistema atual, os "backup", já realizados diariamente, a restauração possa ser realizada corretamente;

d.) Implementar política que garanta facilidade nos cruzamento de dados que permitindo acesso a informações gerenciais rápidas.

Quanto às atividades de cadastro de doadores de sangue, fundamentais à qualidade dos dados, merecem ser revistas, reformuladas. Todos os trabalhadores, diretamente relacionados às atividades, devem ser reciclados e treinados.

Está claro que, para a melhoria da qualidade dos dados e agilidade nos cruzamentos que possibilitem facilitar a gerência do Hemocentro de Botucatu, além do acesso fácil às informações para realização de trabalhos científicos, só será possível se houver investimentos financeiros significativos com a atual empresa, SBS, ou outra, capacitada a atender às necessidades atuais de informação.

\subsection{Captação e Capacitação de doadores de sangue}

As informações de que o consumo de bolsas de concentrado de hemácias não sofre variações importantes de um mês para o outro reforça a necessidade em se manter as atividades de coleta sem grandes implementos nos candidatos à doação, por conseqüência, de coletas, acabando com o Modelo Mental de que há falta de sangue em períodos de festas e feriados. A exposição das informações a todos os trabalhadores envolvidos com a capacitação de doadores de sangue reforça o entendimento, mais próximo, da realidade e favorece e incentiva aspecto do Domínio Pessoal, em busca do Pensamento Sistêmico e o aprendizado em equipe. 
O domínio dos instrumentos de comunicação pelos profissionais que realizam atividades de Relações Públicas que incluem: a Marca do Hemocentro, a publicidade e a propaganda, através do entendimento e aproximação da realidade, é fundamental para um desempenho ordenado.

As expectativas que essa atividade de comunicação gera, incluindo àquelas "corpo-a-corpo", precisam ser compartilhadas não só entre os profissionais ditos, hoje, de captação de doadores, mas com todas as equipes e trabalhadores que mantêm contato direto com o doador de sangue, que também são captadores e capacitadores potenciais. Compartilhando as expectativas geradas aos doadores é possível alcançar as atitudes necessárias para corresponder a essas expectativas. A conseqüência esperada é a retenção de maior número de doadores saudáveis.

A forma de compartilhar informações sobre expectativas entre os trabalhadores, que se propõe, é a Roda ${ }^{87}$, como espaço de comunicação formal a ser criado.

A Roda ${ }^{87}$ deve permitir a interpretação dos resultados deste trabalho, criar a possibilidade de diálogo e de construção da realidade, contrária a procedimento comum de manter informações engavetadas ou utilizá-las para manter espaços de poder individual ou entre poucos.

As medidas de desempenho podem ser realizadas analisando a evolução do número de doadores em primeira doação e de doadores de repetição, em dados obtidos mensalmente.

A capacitação dos doadores de sangue deve objetivar a consciência, a responsabilidade sobre a necessidade da comunidade em manter estoques adequados de sangue aos pacientes nos hospitais e serviços de ambulatório, conforme importante idéia central destacada no Discurso do Sujeito Coletivo dos doadores freqüentes, entre as motivações em voltar a doar. Da mesma forma, o incentivo ao altruísmo e de ressaltar a importância do autocuidado e dos impedimentos clínicos para doação em relação à proteção do doador e do receptor. Deve-se levar em consideração questões culturais religiosas e de cidadania dos indivíduos ou das diversas populações potencialmente aptas a se candidatar.

São fundamentais, nas palestras ou eventos de capacitação de doadores de sangue, as informações sobre o medo de infecções por doenças transmissíveis, o medo da agulha e também sobre janela imunológica quando o público de candidatos a doação for composto por jovens ou indivíduos que ainda não realizaram doações. Estas questões devem ser incorporadas no discurso de maneira sistemática.

Também deve ser sistemático o contato e a tentativa de convencimentos do empregador ou das empresas, para que olhem "com bons olhos" os doadores de sangue ressaltando sua importância em manter a comunidade abastecida com relação às necessidades de sangue.

\subsection{Recepção e cadastro de doadores de sangue}

Como os próprios trabalhadores sugerem, em seu Discurso do Sujeito Coletivo, a recepção não pode ficar, sob qualquer hipótese, sem alguém que possa recepcionar os doadores.

A recepção deve indicar, com clareza, os horários de funcionamento do serviço e seus funcionários devem estar aptos a fornecer informações genéricas sobre 
os preparos para a doação, condições necessárias de saúde do doador e possíveis impedimentos, mesmo nos dias em que não há coleta de sangue.

O primeiro contato é fundamental, pois pode iniciar o estabelecimento do Vínculo entre o doador e o trabalhador, no serviço Hemocentro.

$O$ Vínculo deve significar a corporificação consciente do trabalhador do ato da doação de sangue. Deve ser percebida com o duplo sentido que tem, pois doação e recepção podem ser entendidas como faces diferentes do mesmo ato. $\mathrm{O}$ trabalhador, quando faz a intermediação da doação, pode e deve participar da significação que o ato de doar propicia: o ato de dar continuidade à vida. Se o trabalhador consegue manter este posicionamento em suas atividades, obterá, certamente, a recompensa, o bem-estar, o prazer com o trabalho: o Vínculo.

A consciência é fortalecida pelo conhecimento de todo o ciclo do sangue, de suas aplicações e circunstâncias determinantes no ambiente hospitalar, os cuidados que despende. O conhecimento das necessidades, das circunstâncias que envolvem o doador e a doação de sangue, fortalece um dos aspectos da disciplina do Domínio Pessoal: o noção cada vez mais próxima da realidade.

O cadastro, no sistema de informações, então, é fundamental para a manutenção de possíveis contatos com o doador de sangue. Deve ser preciso, real. A recepção adequada do doador deve exigir do recepcionista a maior atenção a todos os cadastros realizados. $\mathrm{O}$ cadastro não deve ser apenas uma atividade burocrática, mas sim significar a possibilidade real de contato posterior com o doador de sangue.

Principalmente em coletas externas de sangue, o cadastro deve ter a atitude de zelo necessária por parte do trabalhador incumbido da recepção.

A manutenção das coletas externas, hoje, ainda, necessárias, não deve prescindir da qualidade dos cadastros e das informações que possibilitem bloqueio de doadores por motivos de tempo decorrido da última doação ou mesmo por inaptidão clínica ou sorológica relacionada a doações anteriores. Um computador portátil com capacidade suficiente para armazenar os dados referidos constitui instrumento útil no alcance da garantia da qualidade dos cadastros e, em última instância, do sangue.

A identificação do doador deve ser realizada no momento de sua recepção e deve direcionar todos os contatos entre os doadores e os trabalhadores das diversas áreas subseqüentes à doação.

\subsection{Triagem clínica}

\section{Indicadores}

As perdas de bolsas de sangue por exames sorológicos reagentes que têm custo elevado justificam a rigorosidade na Triagem Clínica (TC). A diminuição da coleta em uma única bolsa de sangue que seria descartada por sorologia reagente compensa a inaptidão clínica na triagem, quantas forem necessárias.

Sugere-se indicador individual, por profissional triador: Taxa de Inaptidão Clínica Individual $=\frac{N^{\circ}{ }^{\circ} \text { de Doadores Aprovados TC X } 100}{N .^{\circ} \text { Candidatos a Doação }}$

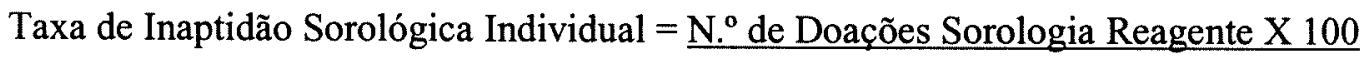
N. ${ }^{\circ}$ Doações Realizadas 
Os indicadores devem ser observados mensalmente e só fazem sentido se forem analisados periodicamente.

\subsection{Coleta de sangue}

\section{Agilidade no atendimento}

Atendimento ágil foi idéia central que se apresentou tanto nos discursos dos doadores ( $F: 2,6 \%$ e $F: 3,8 \%$ ), quanto nos dos trabalhadores (F: 15,4\%), precisa ser considerado e implementado de forma consciente e responsável.

\section{Facilidade de acesso}

Outra idéia central, estreitamente relacionada à agilidade do atendimento, é a facilidade de acesso dos doadores ao local de coleta de sangue, que aparece no Discurso do Sujeito Coletivo de doadores freqüentes (F: 2,6\%) e dos doadores de evento único ( $\mathrm{F}: 23,1 \%$ ), nestes como motivação a não voltar a doar e, naqueles, como dificuldades ou problemas encontrados para a doação de sangue. Considerando-se a importância dos aumentos dos custos de coletas externas, relacionados ao tempo e transporte de equipamentos e pessoal, deve-se estabelecer diretriz política do Hemocentro em descentralizar as coletas de sangue para local de fácil acesso dentro da cidade de Botucatu, como posto fixo.

\section{Indicadores}

Monitorar acidentes de punção com a finalidade de reflexão e aprendizado pelo grupo, além de controle e de objetivar a realidade. Propõe-se dois indicadores:

Taxa mensal de acidentes de punção $=\underline{N^{\circ}{ }^{\circ} \text { de acidentes de punção X } 100}$

$$
\text { N. }{ }^{\circ} \text { de doações mensais }
$$

Taxa mensal individual de acidentes de punção $=\underline{\mathrm{N}} .^{\circ}$ de acidentes de punção $\mathrm{X} 100$

$$
\text { N. }{ }^{\circ} \text { de doações mensais }
$$

\subsection{Captação, capacitação e marketing}

Manter o direcionamento atual de captação e capacitação de doadores de sangue parece ser a atitude mais acertada:

a) empresas que tenham anseios maiores que somente o lucro e que já estejam voltadas em servir, não só a comunidade interna, de trabalhadores, mas a comunidade externa, do município onde estão inseridas;

b) faculdades e universidades focalizando principalmente os novos alunos; 
c) Tiro de Guerra: como apontado pelo Discurso do Sujeito Coletivo dos doadores freqüentes, muitos tiveram sua motivação inicial no período de serviço militar;

d) Atividades de capacitação em escolas (projeto "Doador do Futuro", projeto com alunos bolsistas da Pró Reitoria de Extensão Universitária da UNESP - PROEX).

A expansão da cobertura de captação e capacitação de doadores de municípios da região onde ocorrem coletas externas é outra atividade que merece ser mantida, ainda que haja dificuldades: o III Encontro de Captadores da Região de Botucatu é o meio de escolha para dar continuidade e subsídios aos municípios.

As atividades de Relações Públicas são efetivas e bem desempenhadas por profissional prestador de serviços que tem acesso aos principais meios de comunicação do município e grande facilidade na abordagem necessária ao desempenho destas atividades.

Não há, contudo, orçamento para a realização de divulgação de eventos relacionados à doação de sangue ou mesmo para realização de propagandas, mesmo para divulgação de coletas. Muitas vezes, ao invés de propagandas, são programados contatos de publicidade, gratuitos, para a divulgação dos eventos e atividades do Hemocentro.

A discussão sobre uma Marca para o Hemocentro não foi iniciada e merece atenção profissional. Uma Marca deve traduzir o que o Hemocentro é, traduzir, instantaneamente, as necessidades de doação e o forte convite para que essa necessidade seja atendida, em termos de qualidade e de bom atendimento que corresponda às expectativas do doador. A conseqüência esperada é de quantidade $\mathrm{e}$ qualidade adequadas das bolsas de sangue coletadas.

Apesar de haver inúmeras formas de divulgação publicitária do Hemocentro, não há associação com uma Marca.

A propaganda, ainda que por via patrocinada, é o caminho para divulgação da Marca do Hemocentro. A sustentação desta Marca deve acontecer não só entre os dirigentes do Hemocentro, mas por toda a comunidade que o compõe; deve ser compartilhada.

\subsection{Estrutura e processos}

\subsubsection{Comunicação}

\section{Espaços formais de comunicação no Hemocentro}

É fundamental a criação de espaço formal de comunicação. Dentro de visão holística entre "partes e todo", acredita-se que não seria suficiente a criação de espaço formal de comunicação somente àqueles trabalhadores que apresentam algum tipo de contato com doadores de sangue, sendo que outros espaços devem ser criados em outros locais, dentro do Hemocentro. O mesmo pensamento poderia ser usado com relação ao Hospital das Clínicas, até à Faculdade de Medicina, como pequenas células compondo um organismo, uma organização complexa aberta e capaz de se modificar. 
Sugere-se que seja de periodicidade de três vezes por semana, sob o risco de servir alimento às fofocas nos intervalos entre as Rodas.

No Instituto de Assistência Médica ao Servidor Público Estadual - IAMSPE, há cerca de um ano foi criado espaço formal de comunicação, pela superintendência daquele órgão, que ocorre diariamente, nos fins-de-tarde, "O Sarau". O título é extremamente adequado, pois envolve festa, música e dança, sugere leveza no tratamento das questões em ambiente rico em trocas de conhecimentos e significados e que propicia flexibilidade individual e contenção dos participantes do grupo no tratamento das questões de trabalho.

\section{Preceitos para a formação da Roda}

Treinamento, certamente, não é a palavra mais adequada para expressar mudanças que transformem todas as atividades de trabalho e relações que possam determinar a melhoria de qualidade do sangue ou dos hemocomponentes.

Sugerem-se preceitos e linhas facilitadoras à implementação ou à abordagem das diversas questões, de domínio pessoal, objetivos comuns de trabalho, modelos mentais, aprendizagem em equipe, pensamento sistêmico e outras, expostas ou não, a serem desveladas pelo grupo, assimiladas e corporificadas de maneira a alcançar a referida melhoria de qualidade:

1) Compromisso com a verdade;

2) Compromisso com o diálogo como fluxo de significado;

3) Procura constante por conhecimentos sobre a realidade;

4) Determinação de propósitos pessoais e organizacionais;

5) Abolir a hierarquia: todos são iguais, no grupo. Imposições não têm espaço, sendo permitido o Apoio ${ }^{87}$;

6) Centralização da atenção em processos e menos em descrições de tarefas;

7) Privilegiar, sobretudo, as relações;

8) Buscar identificar mensagens divergentes e modelos mentais;

9) Identificar soluções paliativas e diferenciá-las das duradouras;

10) Cultivar a paciência na expectativa de soluções duradouras que demandam defasagem de tempo.

A evolução da consciência, do desenvolvimento da mente, não acontece de forma linear; mas, sim, de maneira fluida e harmoniosa, como espirais, redemoinhos e correntezas, como ressalta WILBER ${ }^{94}$. Esta característica de desenvolvimento é apresentada por centenas de diferentes pesquisadores. Carl Gustav Jung, citado por SILVEIRA ${ }^{77}$, diz que este desenvolvimento das várias potencialidades humanas, que caracteriza como processo de individuação, não consiste num desenvolvimento linear e, sim, de movimentos de circunvolução que conduzem a novos centros psíquicos.

Então, estes dez preceitos funcionariam como variáveis não-lineares nas quais todas as informações, geradas ou trazidas à Roda, seriam submetidas. Os resultados, na forma de padrões de comportamento, funcionariam para auto-referência.

CAPRA ${ }^{95}$ relaciona esta não-linearidade com os comportamentos complexos e aparentemente caóticos, mas que exibem, em um nível mais profundo, uma ordem padronizada. Esta ordem subjacente aparece como resultado de diversas iterações, ou 
seja, como resultados decorrentes de realimentações das informações produzidas pela Roda, para a própria Roda: um fractal dinâmico.

Estes dez preceitos precisam ser pactuados entre os participantes do grupo para que não haja maiores riscos em expor tais participantes ou desviar e, até mesmo, comprometer os resultados que se pretende obter.

A Verdade, que se faz referência, é aquela conceituada por VARELA ${ }^{96}$ como verdade relativa: o mundo dos fenômenos exatamente como ele parece ser, onde se pode fazer distinções, no mundo relativo, entre afirmações verdadeiras e afirmações falsas.

Sugere-se, como programação:

a) Conhecimento sobre todo o ciclo do sangue, como forma de abordar a organização parcelar do trabalho: acompanhar ato transfusional;

b) Exposição dos resultados e idéias centrais do Discurso do Sujeito Coletivo dos doadores (os dois grupos) e dos trabalhadores e diálogo entre os membros do grupo;

c) A Normose da fofoca;

d) "O Olho do Doador" - reconhecimento dos caminhos do doador em busca da doação: o que pode mudar?

e) Expectativas: doadores $\mathrm{X}$ trabalhadores: melhoria da captação;

f) Problemas cotidianos: o exemplo dos acidentes de punção.

A Roda ${ }^{87}$ pode ser utilizada como instrumento metodológico e espaço formal de comunicação para desencadear o diálogo sobre todo o processo, desde a captação ou capacitação dos doadores de sangue, recepção, seleção e triagem clínica, coleta do sangue e hidratação ou lanche dos doadores de sangue, até mesmo os atendimentos clínicos aos doadores inaptos. Portanto pode, senão deve, envolver os trabalhadores que mantêm contato direto com os doadores de sangue, mas outros trabalhadores de áreas correlacionadas.

$\mathrm{O}$ intuito da Roda deve transcender as informações sobre as características dos doadores de sangue e tomar a direção do Vínculo e do Pensamento Sistêmico.

A Roda deve ter o subsídio de informações administrativas e de produção para possibilitar a aproximação, desejada, com a realidade.

A sistematização das informações e dos diálogos que forem desencadeados por intermédio da Roda podem ser utilizados, tanto para identificar novos Modelos Mentais quanto para funcionar como ferramenta para sua desmistificação no reconhecimento da realidade atual que reforça a Visão do grupo.

A Roda é instrumento utilizado dentro do "Agir Paidéia", Paidéia, como conceito, tem o significado do desenvolvimento integral das pessoas, construção de novos padrões de relação, abordado por CAMPOS ${ }^{87}$. O Método Paidéia sugere "valer-se do Vínculo para estimular os grupos e as organizações a participarem da resolução dos próprios problemas". O Efeito Paidéia é "processo social e subjetivo 
em que pessoas ampliam sua capacidade de buscar informações, de interpretá-las, objetivando compreenderem-se a si mesmas, aos outros e ao contexto, aumentando, em conseqüência, a possibilidade de agir sobre estas relações" 87.

No desenvolvimento da Roda, deve-se ter a preocupação de desenhar as linhas que a aprendizagem for tomando para si, seu desenvolvimento no tempo. Sugere-se a realização de um Mapa Histórico ${ }^{76}$. A intenção seria a de não repetir ou não retornar a assuntos já discutidos e definidos, senão por novas informações ou modificações do ambiente. Se isto ocorre, seria indício de que os diálogos não estariam sendo verdadeiros e que estaria ocorrendo manipulação e jogo de interesses ou resistências a mudanças, não declaradas e, de alguma forma, diversos daqueles expostos na Roda. Precisam ser identificados e apontados. A abertura da Roda, com a exposição do Mapa, pode ser uma forma de evitar a situação exposta.

Os valores individuais ${ }^{76}$ também precisam ser identificados e respeitados, pois, em geral, quaisquer mudanças planejadas podem gerar mágoa quando há desconsideração desses valores e das aspirações pessoais.

O resultado esperado de funcionamento da Roda é de que ela permita o livre fluxo de informações, de qualquer procedência, para a reflexão do grupo, em espaço aberto às diversas possibilidades e que as iterações destas informações com as diversas soluções individuais produzidas, de forma criativa e livre, produza novas informações e o desencadeamento de atitudes no sentido de melhoria da qualidade do trabalho, das relações e do sangue.

\section{Recursos Humanos}

Mesmo adotando medidas paliativas, criar perspectivas para resultados duradouros (medidas de longo prazo) em termos de adequação do número de trabalhadores, de todas as áreas do Hemocentro; mas, especificamente, daquelas que estejam em relação de contato com doadores de sangue, objeto imediato deste trabalho, sem perder a visão sistêmica, base teórica adotada. O mesmo vale para valores salariais e formas de contrato de trabalho, das mais diversas, hoje, existentes.

Compreensão do período de defasagem de tempo é fundamental para o desenvolvimento de atitudes de paciência, sem deixar diminuir a Tensão Criativa, mobilizadora de forças para a mudança.

O organograma atual, elaborado nos modelos da escola neoclássica de administração staff-linha, não satisfaz as necessidades estruturais existentes hoje, havendo espaços de poder não preenchidos ou preenchidos de forma inadequada. Contudo, uma administração centrada, principalmente, em desenvolver as relações no trabalho, em íntima relação com espaços abertos de comunicação, deve diminuir, ao mínimo, as necessidades de uma hierarquia formal sem, da mesma maneira, cair na informalidade, no sentido pejorativo: haveria, sim, o fortalecimento das relaçóes, onde estaria centralizado o poder organizacional.

Considera-se que, além de ser dificil uma reestruturação do organograma do Hemocentro, o provimento adequado dos cargos e, mesmo, ajustes salariais que corrigissem as distorções e diferenças existentes hoje, pelas considerações realizadas anteriormente, sejam muito provável não haver resultados diferentes dos atuais. 


\subsubsection{Expectativas dos doadores de sangue}

A satisfação do doador está intimamente relacionada à expectativa que ele tem sobre o que ele vai encontrar, sobre como será seu contato com os trabalhadores, como vai ser recebido, sensações de conforto que irá perceber, sensações sobre o sabor do lanche e, principalmente, a sensação esperada de reconhecimento do seu ato de doação. Pode ser de "um tapinha nas costas", mas pode ser do reconhecimento religioso, um ato crístico, pode ser também um ato cidadão. Muitas destas expectativas são criadas através de publicidade e propaganda; mas, grande parte destas expectativas, está relacionada ao contato "corpo-a-corpo" realizado pelo captador, no processo de capacitação, e que mostra a imagem do Hemocentro.

Se não houver o reconhecimento destas expectativas, por melhor que seja o atendimento oferecido ao doador, não haverá uma satisfação plena percebida. Assim, o convite para que o doador retorne para uma nova doação perde o sentido de ser se não forem identificadas e satisfeitas suas expectativas. THOMSON ${ }^{65}$ afirma que existe forte prognóstico para que doadores seguros voltem a doar e que este prognóstico está relacionado ao tratamento dispensado pela equipe do serviço de sangue e pelo bem-estar durante e imediatamente após a doação.

As formas de identificação das expectativas do doador precisam ser discutidas por toda a equipe com quem o doador mantém relações diretas, sugerindose que o espaço para esta abordagem seja a Roda.

\subsection{Avaliação}

As propostas apresentadas de metodologia, de resultados e nas conclusões representam um caminho, entre vários. Assume-se, aqui, o conceito de avaliação que pressupõe a existência de três preceitos, dentro do processo técnico-administrativo destinado à tomada de decisões: medir, comparar e emitir juízo de valor ${ }^{92}$, admitindo-se a parcialidade que representa este caminho, esta escolha, que compartilha a descrição de WHEATLEY ${ }^{93}$, que afirma que "toda a observação é precedida de uma escolha do que observar" e que "quando resolvemos fazer experimentos sobre determinado aspecto, perdemos a capacidade de perceber quaisquer outros (...)" e que "nenhuma modalidade de medição é neutra".

Assim, nas entrevistas, por menores que fossem as interferências desejadas do observador ou entrevistador, seus resultados são o resultado de uma interação.

A jornada desde as primeiras idéias até a finalização e apresentação, temporal, deste trabalho, levou em consideração a complexidade, a multidisciplinaridade na busca de soluções simples, por princípio, mas que possibilitassem o crescimento individual apontado por SENGE ${ }^{73}$, também apontado por CAMPOS ${ }^{87}$ e o processo de individuação ${ }^{77}$ dos trabalhadores e dos doadores de sangue. Desta forma, como reconhecimento da interdependência de todos os aspectos da realidade, pretende-se que as abordagens propostas sejam transdisciplinares, na medida em que devem resultar do encontro de várias disciplinas do conhecimento, superando a fragmentação deste conhecimento, do encontro de axiomáticas comuns, como esclarece WEIL ${ }^{97}$.

A escolha da metodologia do Discurso do Sujeito Coletivo ${ }^{75}$ propiciou a apresentação de resultados que podem ser abordados como variáveis: as idéias 
centrais. Esta forma de abordagem, ainda que trabalhosa, propicia a obtenção de informações surpreendentes.

Sugere-se que a forma de avaliação das mudanças, tanto dos trabalhadores como dos doadores, qualitativa, seja realizada pela mesma metodologia do Discurso do Sujeito Coletivo, talvez com as mesmas questões que auxiliaram na construção dos resultados apresentados tendo, nos Modelos Mentais identificados, uma das bases comparativas para a constatação das mudanças.

A criação dos espaços formais de comunicação e sua efetiva implantação e implementação permitiriam um momento propício para avaliar-se, entre um ano e meio e dois anos, prazo para ocorrência de mudanças não somente externas; mas, individuais, internas.

As mudanças externas podem ser dimensionadas com indicadores numéricos, atualmente constantes nos sistema de informações, os indicadores de rejeição clínica e de rejeição sorológica, já propostos, sendo fundamental o acompanhamento efetivo de sua construção e apresentação. 


\section{REFERÊNCIAS}

1. Dietz NM, Joyner MJ, Warner MA. Blood Substitutes: Fluids, Drugs, or Miracle Solutions? Anesth Analg 1996; 82: 390-405.

2. Bryson GL, Laupacis A, Wells GA. Does Acute Normovolemic Hemodilution Reduce Perioperative Allogenic Transfusion? A Meta-Analysis. Anesth Analg 1998; 86: 9-15.

3. Amorim Filho L. HEMOTERAPIA: UMA ABORDAGEM HISTÓRICA E SOCIAL. In: Escola Politécnica de Saúde Joaquim Venâncio (org.). Textos de Apoio em Hemoterapia: volume I. Rio de Janeiro: Editora FIOCRUZ; 2.000. p. $15-26$.

4. Tretiak R, Laupacis A, Rivière M, McKerracher K, Souêtre E. Cost of Allogenic and Autologous Blood Transfusion in Canada. Can Med Assoc J 1996; 154 (10): 1501-1508.

5. Santos LAC, Moraes C, Coelho VSP. A Hemoterapia no Brasil de 64 a 80 . PHYSIS - Revista de Saúde Coletiva 1991; 1 (1): 161-182.

6. Anjos GL. Doações de Sangue no Hemocentro de Botucatu - São Paulo. São Paulo; 2.000.[Dissertação de Mestrado - Faculdade de Saúde Pública da USP].

7. Brasil. Portaria n..$^{\circ} 1376$, de 19 de novembro de 1993. Aprova alterações da Portaria $n .^{\circ} 721 / G M$, de 9 de agosto de 1989, que aprova Normas Técnicas para coleta, processamento e transfusão de sangue, componentes e derivados $e$ dá outras providências. Diário Oficial da República Federativa do Brasil. Brasília, 19 de novembro de 1993.

8. Brasil. Portaria n..$^{\circ} 2.135$, de 22 de dezembro de 1994. Aprova alterações na Portaria $n^{\circ} 1376$ de 19 de novembro de 1993, que aprova Norma Técnica para coleta, processamento e transfusão de sangue, componentes $e$ derivados. Diário Oficial da República Federativa do Brasil. Brasília, 22 de dezembro de 1994.

9. Brasil. Portaria n. ${ }^{\circ} 2.009$, de 4 de outubro de 1996. Completa os termos da Portaria $n .^{\circ} 1376$, de 19 de novembro de 1993, que aprova Normas Técnicas para coleta, processamento e transfusão de sangue, componentes $e$ derivados. Diário Oficial da República Federativa do Brasil. Brasília, 4 de outubro de 1996.

10. American Association of Blood Banks. Technical Manual. $13^{\text {th }}$ Edition. Bethesda; 1.999. 
11. Brasil. Lei n. 1.075 , de 27 de março de 1950. Dispõe sobre a doação voluntária de sangue. Diário Oficial da República Federativa do Brasil, Rio de Janeiro, 27 de março de 1950.

12. Lima VMLM. O sangue deve ser utilizado de maneira racional. Saúde em Debate 1987, set./out.: 51-53.

13. Brasil. Lei n. ${ }^{\circ} 4.701$, de 28 de junho de 1965. Dispõe sobre o exercício da atividade hemoterápica no Brasil e dá outras providências. Diário Oficial da República Federativa do Brasil, Brasília, 28 de junho de 1965.

14. Brasil. Decreto Lei n. $^{\circ} 211$, de 27 de fevereiro de 1967. Dispóe sobre o registro dos órgãos executivos de atividades hemoterápicas a que se refere o artigo $3 .^{\circ}$ da Lei $n .^{\circ} 4.701$, de 28 de junho de 1965 , e dá outras providências. Diário Oficial da República Federativa do Brasil. Brasília, 27 de fevereiro de 1967.

15. Brasil. Decreto . $^{\circ} 60.969$, de 7 de julho de 1967. Regulamenta disposiçôes do Decreto-Lei $n .^{\circ} 211$, de 27 de fevereiro de 1967. Diário Oficial da República Federativa do Brasil. Brasília, 7 de julho de 1967.

16. Serinolli MI. Evolução da Medicina Transfusional no Brasil e no Mundo. Revista de Hematologia e Hemoterapia 1999; 5 (1): 16-38.

17. São Paulo. Decreto Estadual n. ${ }^{\circ} 12.342$, de 27 de setembro de 1978. Aprova $o$ Regulamento a que se refere o artigo 22 do Decreto-Lei $n .^{\circ} 211$, de 30 de março de 1970 que dispõe sobre as normas de promoção, preservação e recuperação da saúde do campo de competência da Secretaria de Estado da Saúde. Diário Oficial do Estado de São Paulo. São Paulo, 27 de setembro de 1978.

18. Santos LAC, Moraes C, Coelho VSP. Os Anos 80: A Politização do Sangue. PHYSIS - Revista de Saúde Coletiva 1992; 2 (1): 107-149.

19. São Paulo. Lei n. ${ }^{\circ} 5.190$, de 20 de junho de 1986. Dispõe sobre a realização de testes para deteç̧ão de anticorpos do vírus da Síndrome da Deficiência Imunológica Adquirida (AIDS). Diário Oficial do Estado de São Paulo. São Paulo, 20 de junho de 1986.

20. Ferreira SH, Carvalho RI. O Brasil Precisa de Sangue. Ciência Hoje - SBPC 1989; abr. 9 (52): 45-61.

21. Brasil. Resolução CIPLAN n. ${ }^{\circ}$ 009, de 13 de outubro de 1987. Dispõe sobre normas relativas ao atendimento do doador, à ética médica, à biossegurança, ao fluxo a ser seguido pela amostra, à transfusão sangüínea, aos produtos injetáveis de fatores de coagulação e à Vigilância Sanitária. Diário Oficial da República Federativa do Brasil. Brasília, 13 de outubro de 1987. 
22. Brasil. Lei n. 7.649 , de 25 de janeiro de 1988. Estabelece a obrigatoriedade do cadastramento de doadores de sangue bem como a realização de exames laboratoriais no sangue coletado, visando prevenir a propagação de doenças $e$ dá outras providências. Diário Oficial da República Federativa do Brasil. Brasília, 25 de janeiro de 1988.

23. Brasil. Decreto n..$^{\circ} 95.721$, de 11 de fevereiro de 1988. Regulamenta a Lei . $^{\circ}$ 7.649, de 25 de janeiro de 1988, que estabelece a obrigatoriedade do cadastramento de doadores de sangue bem como a realização de exames laboratoriais no sangue coletado, visando prevenir a propagação de doenças. Diário Oficial da República Federativa do Brasil. Brasília, 11 de fevereiro de 1988.

24. Brasil. Constituição da República Federativa do Brasil. São Paulo: IMESP; 1988.

25. Dallari SG. Os Estados Brasileiros e o Direito à Saúde. São Paulo: Hucitec, 1995.

26. Brasil. Lei n. $^{\circ} 8.080$, de 19 de setembro de 1990. Dispõe sobre as condições para promoção, proteção e recuperação da saúde, a organização $e o$ funcionamento dos serviços correspondentes e dá outras providências. Diário Oficial da República Federativa do Brasil. Brasília, 19 de setembro de 1990.

27. Brasil. Decreto n..$^{\circ} 61.817$, de $1^{\circ}$ de dezembro de 1967 . Veda a exportação de sangue humano, de seus componentes e derivados e fixa critérios de destinação. Diário Oficial da República Federativa do Brasil. Brasilia, $1^{\circ}$ de dezembro de 1967.

28. Brasil. Lei n. ${ }^{\circ} 10.205$, de 21 de março de 2001. Regulamenta o $\S 4^{\circ}$ do art. 199 da Constituição Federal, relativo à coleta, processamento, estocagem, distribuição e aplicação do sangue, seus componentes e derivados, estabelece o ordenamento institucional indispensável à execução adequada dessas atividades, e dá outras providências. Diário Oficial da República Federativa do Brasil. Brasília, 22 de março de 2001.

29. Brasil. Portaria n. ${ }^{\circ} 721$, de 9 de agosto de 1989. Aprova Normas Técnicas para coleta, processamento e transfusão de sangue, componentes e derivados $e$ dá outras providências. Diário Oficial da República Federativa do Brasil. Brasília, 9 de agosto de 1989.

30. van den Burg PJ, Vrielink H, Reesink HW. Donor Selection: The Exclusion of High Risk Donors? Vox Sang 1998; 74 (Suppl. 2): 499 - 502.

31. Monteiro JA. A Questão do Sangue. Saúde em Debate 1989; jul.: 17-20. 
32. São Paulo. Decreto n. ${ }^{\circ} 32.849$, de 23 de janeiro de 1991. Cria, no âmbito da Secretaria da Saúde, a HEMO-REDE - Rede Estadual de Hematologia Hemoterapia e dá outras providências. Diário Oficial do Estado de São Paulo. São Paulo, 23 de janeiro de 1991.

33. São Paulo. Decreto n. ${ }^{\circ} 35.110$, de 15 de junho de 1992. Organiza Núcleos de Hematologia e Hemoterapia na Secretaria da Saúde. Diário Oficial do Estado de São Paulo. São Paulo, 15 de junho de 1992.

34. São Paulo. Decreto n. ${ }^{\circ} 35.114$, de 15 de junho de 1992. Organiza as Unidades Sorológicas da Secretaria da Saúde. Diário Oficial do Estado de São Paulo. São Paulo, 15 de junho de 1992.

35. São Paulo. Resolução SS n. ${ }^{\circ} 160$, de $1^{\circ}$ de março de 1994. Aprova Instrução Normativa que dispõe sobre o cadastramento das Unidades de Hemoterapia no Estado de São Paulo e dá outras providências. Diário Oficial do Estado de São Paulo. São Paulo, $1^{\circ}$ de março de 1994.

36. Brasil. Portaria SVS n. ${ }^{\circ} 1.565$, de 26 de agosto de 1994. Define o Sistema Nacional de Vigilância Sanitária e sua abrangência, esclarece competências das três esferas de governo e estabelece as bases para a descentralização da execução de serviços e ações de vigilância sanitária em saúde no âmbito do Sistema Único de Saúde. Diário Oficial da República Federativa do Brasil. Brasília, 29 de agosto de 1994.

37. Brasil. Portaria MS n. ${ }^{\circ} 1.840$, de 13 de setembro de 1996. Cria o Programa Nacional de Controle de Qualidade Externo em Sorologia para Unidades Hemoterápicas. Diário Oficial da República Federativa do Brasil. Brasília, 13 de setembro de 1996.

38. Brasil. Portaria MS n. ${ }^{\circ} 1.544$, de 15 de outubro de 1997. Altera a Portaria MS $n .^{\circ} 1.840 / 96$, passando a ser denominado Programa Nacional de Controle de Qualidade Externo. Diário Oficial da República Federativa do Brasil. Brasília, 15 de outubro de 1997.

39. Serinolli MI. “A Tragédia Vermelha”. Médicos 1999; mar./abr.: 90-94.

40. Brasil. Portaria SVS n. ${ }^{\circ} 127$, de 8 de dezembro de 1995. Institui o Programa Nacional de Inspeções em Unidades Hemoterápicas. Diário Oficial da República Federativa do Brasil. Brasília, 8 de dezembro de 1995.

41. Brasil. Portaria SVS n. ${ }^{\circ} 121$, de 24 de novembro de 1995. Institui, como normas de inspeção para órgãos de vigilância sanitária do Sistema Único de Saúde, o "Roteiro para Inspeções em Unidades Hemoterápicas, conforme Anexo I. Diário Oficial da República Federativa do Brasil. Brasília, 24 de novembro de 1995. 
42. Brasil. Portaria SVS n. ${ }^{\circ} 332$, de 13 de abril de 1999. Credencia técnicos especializados das Vigilâncias Sanitárias estaduais, de nivel superior, para representar a Secretaria de Vigilancia Sanitária do Ministério da Saúde para o desenvolvimento do Programa Nacional de Inspeção em Unidades Hemoterápicas - PNIUH. Diário Oficial da República Federativa do Brasil. Brasília, 14 de abril de 1999.

43. São Paulo. Ofício Circular SERSA/CVS n. ${ }^{\circ}$ 12, de 27 de maio de 1999. Avaliação da Equipe Técnica de Hemoterapia da área de Vigilância Sanitária em Unidades Hemoterápicas. Coordenação dos Institutos de Pesquisa - Centro de Vigilância Sanitária. São Paulo, 27 de maio de 1999.

44. Brasil. Portaria MS n. ${ }^{\circ} 1.334$, de 17 de novembro de 1999. Dispõe sobre a transferência do Programa Nacional de Sangue e Hemoderivados do Ministério da Saúde e demais atividades relativas a sangue e hemoderivados, para a Agência Nacional de Vigilância Sanitária. Diário Oficial da República Federativa do Brasil. Brasília, 8 de setembro de 1999.

45. Deffune E, Alvarado RC, coordenadores. Gestão e Garantia da Qualidade de Hemocomponentes no Hemocentro de Botucatu. Botucatu; 1996 [Projeto apresentado à FINEP para apreciação dentro da rubrica saúde na linha $\mathrm{B}$ de pesquisa, no âmbito do empréstimo FINEP/BID/880/OC-BR. Processo Ref.: 0527/95. Divisão Hemocentro - FM-UNESP].

46. UNESP. Departamento de Clínica Médica da Faculdade de Medicina. Edição Comemorativa 20 Anos (1965-1985). Botucatu (SP); 1985.

47. Oliveira JED de. Plano de Ensino Médico na Faculdade de Botucatu, em São Paulo. Revista da Associação Médica Brasileira 1966; 12 (8): 323-330.

48. Anjos GL dos. Estudo Administrativo - Ambulatório do Hospital de Clínicas da Faculdade de Medicina da UNESP. Botucatu; 1998. [Relatório de Final de Estágio - Departamento de Saúde Pública da Faculdade de Medicina da UNESP].

49. Lima MJR, Deffune E, Alvarado RC. Manual Operacional do Setor de Captação e Atendimento ao Doador de Sangue. $3^{\mathrm{a}}$ ed. Botucatu (SP); 1997.

50. Coelho VSP. Gestão Pública $X$ Gestão Privada do Sangue: Oposição ou Complementaridade? Rev. Adm. Púb. 1992; 26 (2): 116-26.

51. Westphal RG. Donors and the United State blood supply. Transfusion 1997; feb. $37: 237-41$.

52. Piliavin JA. Why do they give the gift of life? A rewiew of research on blood donors since 1977. Transfusion 1990; 30 (5): 447-459. 
53. Keown J. The gift of blood in Europe: an ethical defense of EC directive 89/381. J Med Ethics 1997 Apr; 23 (2): 96-100.

54. Musterman KA, Grindon AJ, Sullivan MT, Trouern-Trend J, Blackmon MJ, Watkins J, Williams AE. Assessment of motivations for return donation among deferred blood donors. Transfusion 1998 Jan; 38 (1): 45-40.

55. Fernandez-Montoya A, Lopez-Berrio A, Luna del Castillo JD. How Some Attitudes, Beliefs and Motivations of Spanish Blood Donors Evolve over Time. Vox Sang 1998; 74: 140-147.

56. Lima VMLM, d'Amorim MAM. Aplicação da teoria de Fishbein e Ajzen no recrutamento de doadores voluntários e periódicos de sangue. Arq Bras Psic $1985 ; 37(2): 110-124$.

57. Santos LAC, Moraes C, Coelho VSP. A Politização do Sangue no Primeiro Mundo. PHYSIS - Revista de Saúde Coletiva 1993; 3 (2): 164-192.

58. Williams AE, Thompson RA, Schreiber GB, Watanabe K, Bethel J, Lo A, Kleinman SH, Hollingsworth CG, Nemo GJ. Estimates of Infectious Disease Risk Factors in US Blood Donors. JAMA 1997 March 26; 277 (12): 967-72.

59. James RC, Matthews DE. The Donation Cycle: A Framework for the Measurement and Analysis of Blood Donor Return Behavior. Vox Sang 1993; 64: 37-42.

60. James RC, Matthews DE. Analysis of blood return behavior using survival regression methods. Transfusion Medicine 1996; 6: 21-30.

61. Liu TC, Kuperan P, Tan C, Lin TK, Lee SH. Structuring a safer donorreplacement program. Transfusion 1998 Apr; 38 (4): 368-72.

62. Folléa G, Bigey F, Wagner A, Vives C, Cazenave JP. Évaluation de mesures destinées à développer la régularité du don de sang. Transfus Clin Biol 1998; 5: 241-250.

63. UNESP. Divisão Hemocentro da Faculdade de Medicina. Normas de Triagem Clínica do Doador de Sangue. Botucatu (SP); 1999.

64. Schreiber GB, Glynn AS, Busch MP, Sharma UK, Wright DJ, Keinman SH. Incidence rates of viral infections among repeat donors: are frequent donors safer? Transfusion 2001 Jun; 41 (6): 730 - 735.

65. Thomson RA, Bethel J, Lo AY, Ownby HE, Nass CC, Wiliams AE. Retention of "safe" blood donors. Transfusion 1998 Apr; 38: 359- 367.

66. Jénicek M. Metanálise em Epidemiologia. In: Almeida Filho N, Barata RB, Veras RP, Barreto ML, editores. Teoria Epidemiológica Hoje - 
Fundamentos, Interfaces e Tendências. Rio de Janeiro: Editora FIOCRUZ; 1998. p. $105-115$.

67. Oswalt RM. A rewiew of Blood Donor Motivation and Recruitment. Transfusion 1977; 17 (2): 123 - 135.

68. Aguilar MJ, Ander-Egg E. Avaliação de serviços e programas sociais. $2^{\text {a }}$ ed. Petrópolis: Editora Vozes; 1995.

69. Cotta TC. Metodologias de avaliação de programas e projetos sociais: análise de resultados e de impacto. Revista do Serviço Público 1998; 49 (2): $105-125$.

70. Campos GWS. Subjetividade e administração de pessoal: consideração sobre o trabalho em equipes de saúde. In: Merhy EE, Onocko R., editores. AGIR EM SAÚDE - um desafio para o público. São Paulo: Editora Hucitec; 1997.

71. Triviños ANS. Introdução à Pesquisa em Ciências Sociais - A Pesquisa Qualitativa em Educação. São Paulo: Atlas; 1987.

72. Campana AO, Padovani CR, Timoiara C, Freitas CBD, Paiva SAR, Hossne WS. Investigação científica na área médica. São Paulo: Editora Manole Ltda.; 2001.

73. Senge PM. A Quinta Disciplina - arte e prática da organização que aprende. $8^{\text {a }}$ ed. São Paulo: Editora Best Seller; 2001.

74. Secco VNDP, Santos IAT, Resende LSR. Divisão Hemocentro: Analisando o Presente e Planejando o Futuro. [Relatório - Resumo de seminário promovido pelo Hemocentro de Botucatu; 2001 out. 06; Botucatu - SP].

75. Lefevre F, Lefevre AMC. O discurso do sujeito coletivo - Um novo enfoque em pesquisa qualitativa (Desdobramentos). Rio Grande do Sul: Editora da Universidade de Caxias do Sul - EDUCS; 2003.

76. Senge PM. A Dança das Mudanças - o desafio de manter o crescimento e o sucesso em organizações que aprendem. $3^{\text {a }}$ ed. São Paulo: Editora Campus; 2000.

77. Silveira N. Jung - Vida \& Obra. $18^{\mathrm{a}}$ ed. São Paulo: Editora Paz e Terra; 2001.

78. Jaworski J. Sincronicidade - O Caminho Interior para a Liderança. $1^{\text {a }}$ ed. São Paulo: Editora Best Seller; 2000. 
79. Basso T, Pustilnik A. Corporificando a Consciência - Teoria e Prática da Dinâmica Energética do Psiquismo. $1^{\mathrm{a}}$ ed. São Paulo: editora Gráfica Palas Athena, 2000.

80. Goswami A. O Universo Autoconsciente - como a consciência cria o mundo material. $5^{\mathrm{a}}$ ed. Rio de Janeiro: Editora Rosa dos Tempos, 2002.

81. Alvarado RC. Identificação e Avaliação dos Custos envolvidos no Processo de Obtenção de Hemocomponentes produzidos no Hemocentro de Botucatu. Botucatu; 2.001.[Dissertação de Mestrado - Departamento de Saúde Pública da Faculdade de Medicina da UNESP].

82. Brasil. Resolução da Diretoria Colegiada - RDC n. ${ }^{\circ} 343$, de 19 de dezembro de 2002. Aprova o Regulamento Técnico para obtenção, testagem, processamento e Controle de Qualidade de Sangue e Hemocomponentes para uso humano. Diário Oficial da República Federativa do Brasil. Brasília, 19 de dezembro de 2000.

83. Donabedian A. PERPECTIVAS EN SALUd PÚbliCA - Garantía y Monitoría de la Calidad de la Atención Médica: un texto introductorio. Primera Reimpresión. México: Instituto Nacional de Salud Pública, 1992.

84. Merhy EE. Em busca da qualidade dos Serviços de Saúde: os serviços de porta aberta para a saúde e o Modelo Tecno-assistencial em Defesa da Vida. In: Cecilio LCO, organizador. Inventando a Mudança na Saúde. São Paulo: Editora Hucitec; 1994.

85. Ferreira AA, Reis ACF, Pereira MI. Gestão Empresarial: de Taylor aos nossos dias - Evolução e Tendência da Moderna Administração de Empresas. São Paulo: Editora Pioneira; 1998.

86. Dejours C. A Loucura do Trabalho - Estudo de Psicopatologia do Trabalho. $5^{\text {a }}$ edição. São Paulo: Cortez Editora; 1998

87. Campos GWS. SAÚdE PAIDÉIA. São Paulo: EDITORA HUCITEC; 2003.

88. Franz M-L. PSICOTERAPIA. São Paulo: Editora Paulus; 1999.

89. Mello AMF. A Programação Neurolingüística e a Psicoterapia Corporal. Revista Catharsis [revista on line] 2004; Disponivel em http://www.revistapsicologia.com.br [2004 Mar 16].

90. Weil P, Leloup J-Y, Crema R. NORMOSE - A Patologia da Normalidade. São Paulo: Verus Editora; 2003.

91. Kotler P. MARKETING para organizações que não visam o lucro. São Paulo: Editora Atlas S.A.; 1994. 
92. Tanaka O Y, Melo C. Avaliação de Programas de Saúde do Adolescente. São Paulo: Editora da Universidade de São Paulo - EDUSP; 2001.

93. Wheatley M J. Liderança e a Nova Ciência. $3^{\text {a }}$ Edição. São Paulo: Editora Cultrix; 2002.

94. Wilber K. Uma Teoria de Tudo. São Paulo: Editora Cultrix; 2003

95. Capra F. A Teia da Vida. $8^{a}$ edição. São Paulo: Editora Cultrix; 2003.

96. Varela FJ, Thompson E, Rosch E. A Mente Incorporada - Ciências Cognitivas e Experiência Humana. Porto Alegre: Artmed Editora; 2003.

97. Weil P, D'Ambrósio U, Crema R. Rumo à Nova Transdisciplinaridade Sistemas Abertos de conhecimento. $3^{\mathrm{a}}$ edição. São Paulo: Summus Editorial; 1993. 
ANEXOS 
Caro Doador:

Com a intenção de melhorar a qualidade do sangue utilizado em transfusões realizadas no Hospital das Clínicas da UNESP e nos hospitais da região de Botucatu, estaremos realizando entrevistas com os doadores que tenham realizado uma única doação no Hemocentro de Botucatu.

A pesquisa tem o nome de "PROPOSIÇÕES PARA A MELHORIA DA QUALIDADE DO SANGUE - HEMOCENTRO DE BOTUCATU" e, um dos objetivos desta pesquisa é esclarecer os motivos pelos quais doadores deixam de realizar suas doações.

Assim, convidamos Vossa Senhoria a participar desta pesquisa, concedendo-nos uma entrevista.

Garantimos o sigilo sobre as informações prestadas e que sua participação não irá interferir nos atendimentos prestados pelo Hospital das Clínicas ou pelo Hemocentro.

Estaremos à disposição para novas orientações e esclarecimentos sobre o andamento da pesquisa.

Concordando em participar, solicitamos que Vossa Senhoria escreva seu nome, seu número do RG e assinatura nos espaços abaixo:

NOME:

RG n.:

ASSINATURA:

GILBERTO LUPPI DOS ANJOS

CRM 64.014

COORDENADOR DA PESQUISA 
Caro Doador:

Nós do Hemocentro estamos satisfeitos com suas doações de sangue e, com a intenção de melhorar ainda mais a qualidade do sangue que coletamos para a realização de transfusões no Hospital das Clínicas da UNESP e nos hospitais da região de Botucatu, estamos realizando entrevistas com doadores habituais para determinar qual sua maneira de viver e seu comportamento.

A pesquisa tem nome de "PROPOSIÇÕES PARA A MELHORIA DA QUALIDADE DO SANGUE - HEMOCENTRO DE BOTUCATU" e um dos objetivos desta pesquisa é de descobrir se estas características do doador habitual de sangue podem nos mostrar onde encontrar novos doadores voluntário e saudáveis.

Assim, convidamos Vossa Senhoria, como doador habitual, a participar desta pesquisa, concedendo-nos uma entrevista.

Garantimos o sigilo sobre as informações prestadas e que a sua não participação não irá interferir nos atendimentos prestados pelo Hospital das Clínicas ou pelo Hemocentro.

Estaremos à disposição para novas orientações e esclarecimentos sobre o andamento da pesquisa.

Concordando em participar, solicitamos que Vossa Senhoria escreva seu nome, seu número do RG e assinatura nos espaços abaixo:

NOME:

RG n.:

ASSINATURA:

$\overline{\text { GILBERTO LUPPI DOS ANJOS }}$

CRM 64.014

COORDENADOR DA PESQUISA 
Caro colega:

(NOME DO PROFISSIONAL)

Eu, Gilberto Luppi dos Anjos, RG n. ${ }^{\circ} 11.801 .610$, agradeço sua colaboração para a pesquisa que tem nome de "PROPOSIÇÕES PARA A MELHORIA DA QUALIDADE DO SANGUE - HEMOCENTRO DE BOTUCATU" na concessão da entrevista sobre seu trabalho e relacionamento com os Doadores de Sangue, comprometendo-me a manter o sigilo sobre as informações coletadas e que serão analisadas em conjunto com as informações de entrevistas de outros colegas de trabalho, visando a melhoria da captação e da coleta de sangue do Hemocentro de Botucatu.

Botucatu, de de 2002.

GILBERTO LUPPI DOS ANJOS

CRM 64.014

COORDENADOR DA PESQUISA 


\section{ENTREVISTA COM DOADOR}

NOME:

ENDEREÇO:

TELEFONE:

DATA:

$\square \square \square \square \square \square \quad S E X O: \square \mathrm{M} \quad \square \mathrm{F} \quad I D A D E \quad(\mathrm{EM}$

ANOS): $\square \mathrm{C}$

ESTADO MARITAL: $\square$ SOLTEIRO $\square$ CASADO $\square$ SEPARADO

DIVORCIADO $\square$ VIÚVO

OCUPAÇÃO:

EDUCAÇAOO(EM ANOS DE ESTUDO):

ETNIA: $\square$ BRANCO $\square$ NEGRO $\square$ ASIÁTICO $\square$ ÍNDIO

SITUAÇAO DE EMPREGO: $\square$ EMPREGADO $\square$ DESEMPREGADO

NÚMERO TOTAL DE DOAÇÕES REALIZADAS:

HABITAÇÃO (EM NÚMERO DE CÔMODOS):

COMPOSIÇÃO FAMILIAR (PESSOAS QUE HABITAM A MESMA RESIDÊNCIA): $\square \square$

PARTICIPAÇÃO EM ORGANIZAÇÕES: $\square S I M \quad \square N A ̃ O$

TIPO DE ORGANIZAÇÃO: $\square$ IGREJA $\square$ CLUBES

$\square$ SINDICATOS $\square$ OUTROS

TRABALHO VOLUNTARIO: $\square \mathrm{SIM} \square \mathrm{ONG}$

MOTIVAÇÃO INICIAL PARA DOAÇÃO: 1.

MOTIVAÇÃO ATUAL PARA DOAÇ̃O:

1.

2.

3.

FATOR DE DESMOTIVAÇÃO:

1.

2.

3.

PARENTE OU AMIGO DOADOR: $\square$ SIM $\square$ NÃO

MOTIVOU A DOAÇÃO: $\square$ SIM $\square$ NÃO 


\title{
O DISCURSO DO SUJEITO COLETIVO DO DOADOR HABITUAL
}

\author{
Você já doou sangue várias vezes, não é? você lembra por que você resolveu \\ doar a primeira vez? Fale um pouco sobre isso.
}

Foi a pedido de um amigo, para doar para uma pessoa, para um familiar, porque a mãe dele tinha sido operada, não é? e existe uma norma aqui do Hospital das Clínicas de pedir doadores para repor o sangue. Ai eu falei "vamos aproveitar. não é??", deu vontade, assim: eu fui, sei lá, com a intenção de ajudar.

A primeira vez eu doei quando estava fazendo serviço militar, foi convocação quando eu fazia o "tiro de guerra". na época soldado. O sargento que incentivava a gente, pediu vários voluntários, ai fui encaminhado para doar. Eu sai do "tiro de guerra", já em noventa e oito, ai eu coloquei na cabeça que eu queria doar, assim. espontâneo mesmo.

Foi voluntário, porque eu... a gente ficou sabendo, não é? a gente vê muitas matérias, a gente sempre escuta no rádio de pessoas que estão precisando e que é muito dificil, não é? que está sempre faltando sangue no hospital. A própria publicidade, de falar da necessidade de doação de sangue, falta de sangue, banco de sangue, que uma doação salvava quatro vidas... conscientização, que têm muitas pessoas precisando. Ai eu resolvi ser voluntária na doação.

Vendo meu pai doar sangue, aquilo foi me motivando, não é? meu pai que doa bastante. Eu cresci com isso e meu pai falava "não, vamos doar, vamos doar". Um amigo meu já tinha doado sangue e encorajou, falou como que é, que não tinha problema nenhum, a minha irmã desceu e falou para mim "ó... estão precisando de 'O negativo' lá no Hemocentro" e... falou "vamos lá?" então: fui.

$O$ motivo maior foi a vontade, não é? o voluntarismo de querer ajudar as pessoas, ajudar às pessoas que necessitam, porque eu acho que tem bastante gente que precisa, não é?

Minha religião, que incentiva as pessoas a fazer este ato de caridade. Quando eu fiz escotismo, então tinha essa vontade de... tinha a vontade de exercer. não é? ser voluntário... foi parte do trote de quando eu entrei no curso, na faculdade $e$, todos acabaram doando e eu entrei nessa e doei também. Onde eu trabalhava naquela época, nós fizemos um conjunto de pessoas e resolvemos ir doar sangue.

Ajudar um amigo que estava precisando, de um acidente, um acidente muito grave que, na época, ocorreu na empresa, não é? e a gente foi convidado para... essa doação. Também, tinha uma irmã. que faleceu com câncer, e eu acompanhei muito tempo. Em cada doação... que ela recebia transfusão, ela melhorava sensivelmente.

Teve uma campanha na empresa que eu trabalho, não é? então, pediram para mim, lá e... eu achei bom, achei interessante.

Foi espontâneo mesmo, não tinha motivo de ter. Foi vontade própria: eu decidi doar e fui doar.

Fiquei lá no hospital, vendo as pessoas que... que passavam, essas pessoas que necessitavam de sangue. Voluntária mesmo, pela própria dificuldade que a gente via, da dificuldade do Hemocentro, de doadores.

Foi por curiosidade eu... resolvi doar pela primeira vez, não é? a curiosidade do que era uma doação de sangue e, também, aproveitei uma dispensa do trabalho. 
Eu procurei me informar sobre com quantos anos eu poderia doar, peso... tudo certinho.

Para a doação teve uma palestra que foi um... quem foi fazer a palestra, mas falou relativamente da importância de sangue.

Saber o tipo de sangue, o tipo sangüíneo.

Foi por envolvimento com uma pessoa, uma menina que não era muito certa das idéias... tem que tirar esse peso da consciência. 


\section{E as outras vezes? Você doou pelos mesmos motivos, ou não?}

Eu faço assim como... de livre e espontânea vontade, nunca foi por outra... sempre foi para ajudar o próximo, simplesmente pelo motivo de estar ajudando alguém, solidário nas pessoas que necessitavam do meu tipo de sangue, por um altruísmo, para continuar doando, ajudando, não é? às vezes, até a salvar a vida de uma pessoa, porque as pessoas precisavam. Vontade própria, mesmo, pelos mesmos motivos humanitários que eu acabei doando e pude fazer isso várias vezes. Eu sou doador, então dou continuidade até o dia que eu puder doar, acompanhando o periodo de poder doar, a cada três... quatro meses.

Comecei a me conscientizar, com as campanhas, que os hospitais precisavam de sangue, que a gente precisa ajudar no banco de sangue, nas cirurgias, porque eu sabia que é dificil, eu conheço os mecanismos de doação, eu conheço os pacientes eu sei que é importante doar sangue. A gente sabe a grande necessidade, a falta, não é? do sangue no banco de sangue. Depois que eu conheci, não vi problema algum, não é? e, até gostei da idéia, ai eu vim voluntariamente.

Sim, espontâneo, sim, espontâneo; nunca porque tinha parente internado. Voluntária, não é? eu ia porque eu queria mesmo. Dava vontade... vontade de doar, mesmo, sem precisar ajudar, mesmo, mas já ajudando, não é? a cada quatro meses aí.. eu estava lá, porque vi, nesta primeira vez, que não tinha nada de mais, não doí, não arrancava pedaço, não tinha nem um mal e, que eu podia fazer isso é... sem problemas.

Sabendo que eu doava sangue, quando as pessoas faziam algum tipo de cirurgia eles acabavam me pedindo, também quando parentes, amigos precisavam de doação de sangue... que tinha parentes no hospital e, eles pedem dez doadores, não é? para reposição.

Cada vez que eu dôo, eu me sinto outra pessoa. Parece que renova alguma coisa dentro da gente. Sei lá... a gente se sente bem melhor, também. Certo? acho que eu me sinto bem; mas, na verdade, é porque eu gosto, mesmo.

Eu sei que de repente pode ser que eu precise, um dia, do sangue de alguém. Eu me ponho no lugar das pessoas: vamos dizer que eu precisasse do sangue e não tivesse, eu poderia até morrer...

Eu falava para o pessoal, um sangue bom, livre de colesterol, livre de tudo, então, tinha que aproveitar.

O principal de tudo isso, também, aqui, pelo meu ponto de vista é... que pelo menos eu estou a par... assim, um "check up" geral do sangue. O pai da criança que estava fazendo cirurgia foi lá atender, receber a gente legal, foi abraçar a gente, cumprimentar... motivou mais, para continuar doando. 
Nestas vezes que você doou, houve algum problema, alguma coisa que dificultou a doação, ou não?

Aqui, nunca senti dificuldades. Todas as vezes eu cheguei, doei, sem problema nenhum. Sabia já das coisas que precisava estar, assim, para doar, os quesitos básicos para doar, então: sem problema nenhum. Muito fácil de encontrar a veia, bombeamento perfeito... nunca aconteceu nada, nem antes e nem depois da doação. Nem vazamento, nada, nada. Nunca me senti mal, sempre correu tudo bem, sempre que eu vou lá sou bem atendido... sempre bom, sempre tranqüilo, graças a Deus! Tenho medo, até hoje, de ver a agulha entrar no meu braço. Depois que a moça "coloca là", normal. Bem estruturado, bem estruturado o Hemocentro... as coisas são bem tratadas, o pessoal trata a gente bem. A recepção é muito agradável, eles te acolhem muito bem, tem uma preocupação enorme se você está bem, não é? se você se alimentou antes da doação, se você está bem de saúde, paparicando a gente e tal.

Fui fazer a doação e, na hora que eu recebi a agulha, no braço direito, eu acho que a moça era inexperiente, tá? ela insistiu que a veia do braço direito era mais... melhor, não é? a moça não estava encontrando a minha veia, então ela colocou a agulha, só que, em vez de ela retirar a agulha inteiramente e colocar, ela tentou dar uma acertadinha, a moça "pegou o nervo", não é? do braço que... que fiquei assim: meio assustado, não é? então, o braço ficou um pouquinho inchado; já aconteceu duas vez. Uma vez que... uma perfuração da minha veia, que eu falei "tudo bem" e houve um derrame muito grande, que ficou muito roxo o derrame que deu. Quando a moça foi arrancar a mangueira para colher o pouco de sangue para fazer os exames, ali, ela derramou um pouco daquilo no meu braço... uma certa imperícia dela ou um descuido na hora, ali.

A segunda vez que eu doei sangue só que... eu acho que a minha pressão baixou demais, que eu fiquei pálido. Foi bem após à doação, eu tinha feito a doação lá na UNESP, mesmo e, após ter chegado aqui na cidade é que eu passei mal, eu "apaguei" um pouco

Teve uma ou duas vezes que eu vim, tinha muita gente, então demorou um pouco e... eu não gosto de esperar.

Ligaram, não é? dizendo para mim voltar lá por causa que eu tinha que fazer novos exames que foi pelo fato de eu ter tomado, há um tempo antes, vacina contra febre amarela.

Fui chamada para doar plaquetas, não é? foram me buscar na data errada... eu não podia, não é?

O que eu falo para todo mundo: gostaria que o posto fosse de atendimento mais próximo do centro, que a gente comenta muito isso ai, para quem é doador da cidade.

No começo eu era conhecido de todos os funcionários, então, não tinha pesquisa, não tinha quase nada, o pessoal conhecia, sabia a idoneidade da gente.

Tomei uma vacina, não é? aquela... acho que é rubéola, não sei o que é que foi lá, e, daí, eu não pude doar.

$O$ único problema era por causa do serviço, porque a empresa ela.. as empresas, hoje, elas aceitam um atestado por ano, de doador... de doação de sangue, não é? então, eu sempre doava... dôo, não é? três vezes ao ano, dois eu 
perdia, quer dizer, eu perdia três dias, não é? que a gente perde o dia da semana, o sábado e o Domingo.

Era o único problema, foi só isso. Foi, assim, coisa passageira; mas, mesmo assim, eu persisti, insisti e fiz a doação no braço esquerdo, dai. Foi a única vez... das outras tudo correu normal, são vinte... vai fazer vinte anos que eu dôo sangue o resto foi tudo normal. Só isso ai; mas, assim, quanto ao atendimento, nenhum. Depois disso nunca mais aconteceu nada. mas ficou normal, correu tudo normal, graças a Deus, tudo normalmente. 


\section{DISCURSO DO SUJEITO COLETIVO - DOAÇÃO ÚNICA}

\section{Na sua ficha, eu vi que você doou sangue só uma vez, não é? por que você resolveu doar?}

Pela oportunidade do local.

Eu queria ajudar, mesmo, na doação, uma coisa tão simples. Estava na semana de natal e foi mais com a intenção de fazer uma boa ação, porque tem muita gente que precisa.

Eu fui acompanhar uma amiga que ia doar, ai eu acabei doando. O incentivo da minha mãe, também, não é? minha mãe sempre doa. A diretora da minha escola me reconheceu, na rua, e me pediu a ser voluntária, a doar sangue e tal... Meu primo era estudante de medicina e ele que veio com essa proposta "oh, vamos doar, pro pessoal?" eu resolvi doar.

Olha, eu sempre tive vontade de doar, certo? Foi por vontade própria, eu tinha essa intenção; assim que eu subi o peso, eu vi a chance de doar.

Era uma gincana, na escola, na época, não é? e eu tive a oportunidade, as escolas daqui de Botucatu: municipais, estaduais, até as particulares estavam fazendo campanha e, eu resolvi entrar na campanha também, para dar o ponto para a escola da minha filha. Eu fiz um concurso para a policia militar e, um dos critérios para você estar passando à frente da fila, porque a fila é muito grande, foi: você doar o sangue para você estar passando na frente nos exames, não é?

Um gesto de salvar uma vida, não é?

Eu estava trabalhando ai eles foram na firma buscar, de perua, trouxeram até aqui que era aqui na esquina da "Misericórdia". A escola combinou... naquela época ligou e pediu que tivessem alunos que pudessem doar mais por isso mesmo: pelo grupo e pela escola, para ajudar na doação de sangue.

Um amigo meu, que trabalhou comigo e ele teve leucemia, não é? e, eu vi que ele precisava. Houve um acidente, na fábrica, com nosso amigo e precisavam de bastante sangue, foi o motivo meu, particular, de doar sangue. Conheço ele de muito tempo.

Eu resolvi doar porque eu via várias propagandas sobre doação de sangue. Um incentivo, não é? da televisão, para doar sangue.

Eu aproveitei para doar, para e saber se está tudo em ordem comigo, sabe? para fazer um check-up geral, não é? Aproveitar que a UNESP oferece o serviço.

Eu não sei meu dia de amanhã, não é? quem sabe, eu posso precisar de alguém que doe para mim, não é?

Lá no quartel, não é? o sargento, ele conversava bastante com a gente, para a gente doar e tal. 
Daí você não doou mais, não é? por que? Fale um pouco sobre isso.

Eu fui doar estava na "Doutor Costa Leite" (rua) $e$, depois, voltou tudo a ser na UNESP, então, para mim, ficou mais longe não tinha facilidade para locomoção até lá: para mim ficou mais dificil, um pouco inviável. O Hemocentro, aqui no centro de Botucatu, ia ser bem mais fácil para a gente estar doando; eu acho que para todo o mundo, não é? É dificil o acesso até a UNESP, não é? Muito longe. Este problema de deslocação, você acaba perdendo uma tarde inteira e isso dificulta bastante.

Por causa da sensação que eu tive, porque eu passei mal, não é? eu tive um desmaio: foi logo depois que eu doei. Daí, eu fiquei com medo: nunca mais eu fui, nunca mais procurei.

Logo depois que eu fiz essa doação eu engravidei, ai eu perdi... eu fiquei grávida uns dois meses, perdi. Aí, depois de um tempo, eu engravidei de novo, então, nesse periodo todo, da primeira doação até agora. Na gestação não pode doar, não é? e, eu parei de amamentar em setembro do ano passado.

Depois, eu tive uns problemas de saúde, eu comecei a fazer um tratamento com uns remédios, não doei mais. Pelo motivo, assim, de eu ter rinite alérgica, então era constante, você entendeu? é muito baixa a resistência da gente. Também, um acidente que eu tive, de trabalho, eu estava tomando uma medicação muito forte, dai eu... uma vez eu fui lá para doar, (...) perguntou se eu estava tomando remédio, eu falei o nome do remédio e ele falou que eu não podia doar mais, até que parasse de tomar esse remédio. Ainda, porque, no meu sangue, deu traço falciforme, dai falaram para mim que eu não podia.

Então... não tive por quê... não fui mesmo doar.

Falta de tempo, a correria do dia-a-dia, a gente nunca teve a oportunidade: quando via, já passava o tempo, passava o ano e eu não conseguia ir até o Hemocentro doar sangue. Eu estava trabalhando demais, por isso. Sou um cara acomodado demais, quer dizer, o defeito mais brasileiro. Então, foi, tipo, um esquecimento meu. "amanhã eu vou doar sangue", é uma coisa tão fácil; então, aquilo: deixa para amanhã. Amanhã ou depois; então, vai... passou. Como você ligou (entrevistador), eu estou disposto a doar sangue hoje, amanhã; mas, é aquilo: vou assumir um compromisso com você, amanhã eu vou lá doar. E, também por falta de... sei lá: às vezes, se me ligassem e falassem "vem, nós estamos precisando que você doe", alguma coisa nesse sentido, não é? de incentivar a pessoa, de lembrar a pessoa, nunca mandaram carta para mim, nada... eu teria ido.

Eu sofri um acidente, não é? perdi muito sangue.

Eu fiquei pensando, porque a gente fica pensando muito em AIDS, em contágio de AIDS, a gente fica meio com tabu, assim, não é? a gente vai lá doar sangue e fica com receio... de repente eles usam uma seringa contaminada, alguma coisa assim. Então, eu não procurei mais doar sangue.

Na verdade, eu fiquei um pouco nervoso, na época. Eu fiquei meio que com medo, certo? Porque nunca tinha feito isso, então eu vi aquela mangueira cheia de sangue me deu... nossa! Fiquei meio assustado, mas... não sei, de repente não... eu falei, "eu não vou doar mais", tal... não deu vontade mais, sabe?

Um dia que eu fui lá, que eu tinha aproveitado visitar uma pessoa, lá... o dia que eu fui, estava fechado. Não tive como, não tive como doar, não é? 
Aí, teve um dia que eu estava mal, assim, mesmo com insônia, dai eu tinha ido lá e acabei sendo liberado para doar sangue, passei mal, não é? e travou minhas mãos, assim, meus braços, assim, as pernas... passei muito mal.

Pelo serviço meu, no caso, assim: não aceitam doar sangue e ter que trabalhar. No caso, se eu doar sangue e ter o meu dia livre, eu não ir no serviço, vão ficar falando, vão ficar argumentando, perguntando o porquê.

Mas eu doei em um hospital em São Paulo, na minha faculdade sempre tem gente que pede, lá... doadores voluntários, então, lá, eu acabei doando.

O processo de doação de sangue, ele é muito demorado, o atendimento, apesar de ser bom, demora um pouco. 


\section{O DISCURSO DO SUJEITO COLETIVO DO TRABALHADOR}

Você é uma pessoa que tem ou não um projeto para sua vida pessoal? fale um pouco sobre isso.

O meu projeto é ter uma família, construir uma familia, ter filhos, eu penso nos meus filhos; porque a gente não é nada sem ter esta base. (M)

Meu projeto é poder educar os meus filhos com a maior qualidade possivel, não é? Dar o melhor para eles, a melhor escola, a melhor estrutura de formação, orientar melhor, junto com meus filhos, que eles descubram alguma coisa, também, que possa, futuramente, desenvolver, criar, gostar: um esporte, pintura... Essas coisas. Eu planejo a minha vida, para os meus filhos, para o meu marido. Meu projeto é esse: levar os filhos para frente, porque se eles estiverem bem, eu estarei bem, entendeu? (U)

Voltar a estudar e se tornar enfermeiro profissional, fazer uma faculdade $e$ ter nivel universitário para trabalhar no meu setor. Vou ter caminhos mais abertos. (M)

Entra na parte profissional, mas que é uma realização pessoal: estudar, continuar os estudos. Pretendo fazer mestrado, fazer curso de inglês, não é? Algum curso, assim, que venha contribuir para o trabalho. (U)

Eu conseguir comprar minha casa própria, conseguir pagar a minha casa, que é muito dificil.(M)

Você quer ter, também, uma casa própria, vai lutar por sua casa própria, você quer ter um carro: você vai lutar para isso. (U)

Viajar com os meus filhos, poder mostrar a parte boa da vida. São sonhos... futuramente, poder ir para o exterior, não é?(U)

Ter um emprego bom, poder manter meus filhos. (M)

Poder ter um bom emprego.(U)

A primeira coisa que eu almejo é paz. $\dot{E}$, diante desta paz, que você vai buscar mais coisas...(U)

Trabalhar com pessoas, trabalhar com vidas lá dentro da igreja, não é? vidas, vidas necessitadas... me doar um pouquinho mais para poder ajudar outras pessoas, também. (U)

Investir em áreas de lazer para me deixar mais calmo, menos estressado. $\dot{E}$ uma compensação do agito do dia a dia. Gosto muito de trabalhos manuais. (U) 


\section{Em relação a sua vida profissional, você tem um projeto para sua vida, ou não?}

Eu estou fazendo "auxiliar de enfermagem" $e$, se eu realmente gostar do que eu estou fazendo, eu vou investir, eu pretendo fazer uma faculdade de enfermagem, mesmo e tentar ingressar nessa área, na área de enfermagem. Ser formado, não é? Ter caminhos abertos para trabalhar no Hemocentro. Ai, eu vou batalhar mais quatro ou cinco anos, depois disso eu pretendo fazer ou aprimoramento ou uma pós... um mestrado, dentro da área da enfermagem e, se der para juntar faculdade de administração, eu pretendo fazer pós, mestrado em administração hospitalar. Aprender mais, subir mais na carreira, na área de enfermagem, mesmo. (M)

Eu quero crescer dentro da minha profissão, não é? Eu sinto que eu estou estagnada... faz cinco anos que eu estou aqui e eu estou parada mesmo. Não só ficar na prática do trabalho, começar a entender um pouco mais... começar a estudar mais, mesmo. Até começar a desenvolver trabalhos que, assim... poça ajudar tanto a gente como o hemocentro. Espero não demorar muito, não é? E, no final deste ano, defender uma tese, no futuro. Com estas informações que você obtém dentro do mestrado ou do doutorado e que você pode aplicar na tua vida profissional. Eu tenho anseio de crescer... de estar estudando, estar fazendo cursos, congressos, agora eu sinto que dá para fazer isto, e eu quero. (U)

Desde que eu entrei, estou na mesma função e não melhorei em nada. Que, também, não me ofereceram nada para eu melhorar. A gente não tem perspectiva, então a gente tem que estar sempre se mantendo atualizado em tudo que está acontecendo, que vai mudando. Não tenho porque estou quase aposentado.(M)

Poderia estar melhor se tivesse muitas coisas que está faltando... eu acho que o trabalho até sairia melhor se ouvissem mais a gente... às vezes ouvem, mas não... vamos dizer assim: ouvem, mas não resolvem. É isso. Então... isso também acaba desanimando, no trabalho. $O$ tempo que a gente ficou aqui, a gente ficou muito parada, parada no sentido, assim... da gente ir buscar outras informações, aprender várias coisas. (U)

Desenvolver projetos, pesquisas. (M)

Desenvolvendo projetos. (U)

$\mathrm{Na}$ área de captação, a gente tem que ser ousado, certo? e, é um trabalho que eu me identifico muito: um, pelo conhecimento das pessoas, um, pela facilidade da minha... do meu contato, certo?(M)

$O$ que mais me move, no projeto profissional, é poder ter a chance de criar, $e$ diferente quando você trabalha com o doador, quando você faz alguma coisa... quando você trabalha diretamente com as pessoas, mudando comportamento ou ajudando emergir um comportamento que está meio que apagado ou a comunidade... (U)

Constantemente a gente está em mudanças, não é? Então a gente tem que estar se adaptando a essas mudanças e são mudanças que exigem novas perspectivas... eu sempre busco ver qual é o motivo que está começando a falhar... sempre busco ver uma nova, um novo incentivo e sempre buscando propostas de melhoria, sempre acompanhando o mercado de trabalho, não é? Então, a gente sempre tem que estar, nesse sentido, se atualizando não adianta grandes idealizações, de repente a gente acaba se frustrando com algumas coisas, não é? Eu tenho sempre em meta, assim... estar sempre atualizando, lendo constantemente, 
estudando constantemente, para me atualizar dentro de tudo que está acontecendo. (U)

Fazer faculdade à noite, já sei o que é isso, já foi quatro anos isso... agora... vamos ver se a verba, agora, dá para fazer. (M)

Também, a por metas dentro de todos os laboratórios aqui e em organizar, não é? organizar melhor... (U)

Tem que se estimular às pessoas para que elas vão para frente dentro de cada área dela, não é?(U)

A gente tem meta de tentar melhorar esse relacionamento no dia-a-dia, tem que estar gerenciando estas coisas instantaneamente, de hora em hora, de dia em dia, entendeu? (U) 
Entre os seus colegas do Hemocentro você percebe um projeto comum de trabalho? fale sobre isso.

Não, ts... ts... nem um pouco! Não tem nem um coleguismo dentro do hemocentro, porque um... vive o seu momento, ali, pensa na pessoa dele, mais a parte só de fazer o serviço deles e só. Nada mais que isso. Outros trabalham, mais, assim: não têm planos de ficar ali mesmo, de construir uma coisa junto. Pouca gente se interessa pela captação de sangue. Quanto a parte da coleta, é pouco o contato, assim... de conversar a respeito disso, de saber e de identificar, entre eles, se tem um plano de trabalho para isso, entende?. (M)

Eu acho que, ainda, nós estamos vivendo muito individualismo. Passamos por um periodo ruim, onde o ambiente de trabalho não era legal, os colegas, estressados... acho que isso individualizou mais ainda a equipe. As pessoas trabalham e não vejo, assim... colaboração para que os doadores possam estar voltando, eu acho isso: que não existe essa integração no nosso trabalho, cada um faz o seu... isso me frustra muito, não é? As pessoas estão muito preocupadas... não me excluo disso, não. Muito preocupados consigo mesmos, com o seu trabalho ali dentro, não vejo que tenha um interesse comum de desenvolver um trabalho, estar fazendo alguma coisa... percebo muito pessoas isoladas, não grupos. Não estamos conseguindo trabalhar, assim, paralelamente; percebo que as pessoas estão trabalhando, assim: muito pessoalmente, elas não estão se entregando em conjunto, não é? São extremamente individualistas, não é? (U)

Uns, eu percebo, assim, que eles têm planos de se estabilizar lá dentro do hemocentro mesmo, crescer lá dentro. Alguns falam que vai estudar. Gostaria de ver estas pessoas como enfermeiros aqui dentro! (M)

Eu vejo, mesmo nas áreas mais simples, você vê que, dentro daquela área dele, o indivíduo, ele está querendo aprimorar, o fazer melhor, sabe? Estar evoluindo. É a própria meta do ser humano, estar evoluindo, evoluindo. (U)

Na verdade, não é? ela ganha como flebo, trabalha como se fosse enfermeira. Um fez o "auxiliar" agora, mas não é auxiliar de enfermagem aqui, registrado no hemocentro. Aqui, ele é auxiliar de laboratório... Outro, que está sendo contratado, mas que também não é funcionário, não é? Está prestando um serviço. Às vezes essa outra pessoa não está no mesmo ritmo que você, não tem aquela... é uma responsabilidade nas suas costas: se não fizer, vai faltar! Se faltar, vai cobrar quem? "Ah, eu sou funcionário, eu não estou aqui para isso", se acontecer um acidente de trabalho com ele, ele não vai ter a mesma cobertura que a gente, que é funcionário, não é? e ele está trabalhando do mesmo jeito que a gente. Você vai receber certo no final do mês, e eu que nem sei se vou receber e tenho que trabalhar', não é? (M)

Funcionários que forem abordados de uma forma digna têm chance de dar certo, de termos uma equipe, mas tem muito que ser feito para chegar lá. Eu percebo, às vezes, que tem muita disputa, aqui dentro. $E$, são poucas pessoas, o que me deixa muito chateado... têm muita disputa aqui dentro, muita rixa, entre um e outro, isso que eu acho que atrapalha um pouco um trabalho mais harmonioso. (U)

Você vai receber certo no final do mês, e eu que nem sei se vou receber e tenho que trabalhar, não é? (M) 
Eu sinto, assim, que as pessoas vêm trabalhar para receber o salário, no final do mês... no meu ponto de vista: um grupo, unido, é lógico com o objetivo, não é? talvez, maior, de sobrevivência do que de realização profissional. (U)

Não vejo ninguém comentar: vamos fazer um negócio diferente para o doador? não vejo! não tem ninguém, não vejo ninguém apresentar projeto de trabalho aqui. A gente não tem um plano de trabalho, hoje, um plano de trabalho para poder desenvolver, no papel, e resolver o dia-a-dia. (M)

É importante saber, também, o que as pessoas estão sentindo e, entre nós mesmos, tentar nos adaptar àquilo que é importante para a gente, qual é o nosso objetivo dentro do hemocentro, dentro da coleta, não é? e eu sinto que o pessoal está bem desintegrado nesse sentido, então? Tem! Tem como a gente poder pensar alguma coisa para somar essa força! (U) 
Agora, eu queria que você falasse um pouco sobre os doadores. Eles são pessoas que têm alguma coisa em comum, ou não?

A maioria deles é de classe baixa, a maioria analfabeta, humilde, eles são umas pessoas simples, simples até demais, que a gente, no olhar deles a gente já vê a feição da classe pobre. Homens, não é? e... é isso: a maioria deles, principalmente aos sábados.

Ás vezes, a gente nem consegue furar o dedo do doador de tão calejada que é a mão, que a pessoa trabalha na roça, mesmo.

São aqueles doadores de reposição, que sempre acabam vindo assim... vêm de longe, não é? mas, assim: por amizade, familia... mas são pessoas que também que... acabam perdendo o seu dia de serviço, pessoas e que "graças a Deus tem a UNESP para cuidar do meu paciente... meu parente".

E mais fácil a gente... você... ter um resultado positivo... com as pessoas... as pessoas de baixa renda, entendeu? para trazer, para poder o trabalho surtir efeito, certo?

Eles não têm uma situação econômica tão boa que possa fazer um almoço, comer um lanche, por conta própria baixa, são doadores que vêm porque precisa doar para alguém, não é?

São pessoas parecidas... na profissão, em termos de classe social, são pessoas semelhantes. Dificil é alguém que se destaque ou diferente desse meio.

A gente não vê gente classe média para alta, quase, doando sangue. Só poucos, os de nivel mais alto, que a gente consegue trazer, concorda?

Uma vez ou outra que você vê dono de empresa parando a fábrica $e$ mandando funcionário vir aqui. Quer dizer... ele não veio doar sangue, ele mandou o pessoal lá em baixo (subalterno) no lugar dele vir doar sangue. Então, ele não tem necessidade... para ele, ele tem um pessoal que pode cobrir a parte social.

$\dot{E}$ uma coisa comum, em todos os doadores, é de ser reconhecido que ele está ajudando a salvar vidas, ajudar, mesmo, vêm para colaborar. Eu acho que a solidariedade, ser solidário, está presente; mas, são muito poucos os que eu vejo, assim, que vêm de coração, sabe "ah, eu vim por vir, porque eu gosto de ajudar" É lógico que tem, não é? voluntários; mas, no meu ponto de vista, são a minoria.

Têm aqueles que vêm só para pegar o atestado, não vêm para doar com a intenção de ajudar o próximo: têm a intenção de pegar o atestado e só isso, mesmo

Percebo, assim, que muitos deles vêm porque tem uma afinidade muito grande com esses... com essas pessoas para quem eles estão vindo doar, não é? vem porque tem alguém que está doente aí.

Todas essas pessoas que a gente procura, só dependem, mesmo, de estímulo, de você conseguir estimular esta população a ser doadores...

Eles ficam felizes quando doam, eu acho que isso é o ponto, porque a pessoa, o ser humano, acho que tem que buscar a felicidade, porque a felicidade é nada mais do que momentos em que você pode se doar de uma forma gratuita, de uma forma que você sabe que está fazendo o bem para o próximo. É um momento de felicidade.

Eu peço para eles ter amor e carinho nas pessoas e um procurar ajudar o outro, porque a gente tá... todos nós estamos no mesmo barco. A gente tinha que tratar o doador igual a gente trata o filho, a esposa da gente, o familiar da gente... está muito a desejar o atendimento do doador, eu acho. O lanche melhorou muito, eu acho que a parte do lanche melhorou, tem uma copeira excelente, acho que está, 
assim: está contribuindo com a parte dela, entendeu? Eu penso que o doador é uma coisa importante, é o combustível do hemocentro. Então, eu acho que ele tem que ser o cara mais tratado do mundo. (M)

A única coisa que eles pedem para nós, que somos flebotomistas, eles pedem para que a doação de sangue não demorar muito, a triagem ser mais rápida... a reclamação deles é nesse ponto, que eles vêm aqui com... como posso dizer... de livre e espontânea vontade. (M)

"Ai, mas eu tenho que trazer dez, moça. Como eu vou fazer para conseguir estes dez, se eles não pode faltar do serviço?" é às vezes, não é? (M)

Não é uma recepção adequada, a gente não tem muitas informações na recepção, entendeu? E, chega ali a recepção, às vezes, está sozinha, não tem ninguém para informar, entendeu? Ele fica lá meia hora, quarenta minutos $e$ ninguém vai lá dar uma satisfação, entendeu? Acontece isso! Tem deficiência na triagem clínica, eu acho, também que, às vezes, não tem alguém para triar, no momento, entendeu? A gente está muito relaxado na sala, eu acho que tem que melhorar. (M)

Eu acho errado, porque se você veio, quer dizer: você veio para doar, não é? Você até sabe que vai comer um lanche depois e, chega ali, as pessoas... não que... algumas pessoas ai, da chefia acabaram... barrando: se não doa, não come. (U)

A gente teria que trabalhar com outro tipo de doadores, eu acho que está faltando um pouco mais de conscientização para a doação de sangue. (U) 
Como é que é o seu relacionamento com estes doadores? fale um pouco sobre isso.

Ah, é fantástico! É ótimo. A recepção é muito grande. Eu me dou muito bem com os doadores, eu tento conversar, puxar assunto lá dentro, pro pessoal não ficar tão nervosa, a gente brinca com eles, a gente dá risada com eles... para mim, eu... acredito que sim. Eu gosto de trabalhar com doadores e não tenho, assim, dificuldades em me relacionar com eles, não.

$O$ meu relacionamento, em primeiro lugar, é de respeito com eles, não é? respeito de ética. eu procuro tratá-los da melhor maneira possivel, eu procuro ser clara, ser gentil, eu tento ser profissional ao máximo, entendeu?

Você pode chegar, cumprimentar, perguntar se está tudo bem, se está bem de saúde, antes de começar aquele monte de perguntas, que são aquelas perguntas, não é? que se o individuo não tiver uma estrutura, assim, ele pode se sentir até ofendido. Então, você tem que fazer uma apresentação da doação, da importância do paciente, da importância para ele estar respondendo verdadeiramente, não é? cumprimentar o doador... eu falo "por gentileza, o senhor estica o braço? a gente vai fazer assepsia..." essa empatia é muito importante: o doador não pode ver você como uma pessoa que sabe muito além dele e, que ele, não tem condição de compreender, porque a maioria dos doadores são pessoas carentes, de baixa renda. Sempre procuro conversar para ver se foi bem atendido e agradeço as pessoas pela doação. Eu acho isso dai muito importante, assim, a respeito de recepção aos doadores, essa atenção... mas, esse relacionamento, não acaba tendo muito contato com eles, porque, como o papel do captador é de sair captando, não é? eu acho que a pessoa, também, se sente muito bem.

Não têm diferença para mim, não: não tem branco, não tem preto, não tem rico, não tem pobre. São todos iguais.

Mas, ao mesmo tempo, não me expor muito, porque, muitas vezes eles levam para o outro lado.

Quando aparecem aqueles doadores mais ruins que, às vezes, não é? ou implica com fila ou implica com alguma coisa, eu acho assim... eu consigo desvencilhar bem quando acontece algum problema.

Eu dou, muito, abertura para o doador se sentir à vontade, eu sinto que o doador se sente à vontade quando ele está falando comigo, não é? quando eles terminam uma doação eu vou lá, eu brinco, eu agradeço, eu, de uma maneira ou de outra, sempre estou convidando para voltar. Então, eu dou muita importância, eu valorizo, eu respeito demais o doador independente de qual a condição de ele estar vindo, não é? mas eu sempre digo que ele é muito importante, não é? eu gosto de frisar isso, eu não vejo diferença entre as pessoas.

Por mais que a pessoa vem com cinco pedras na mão, se você tratar ela com educação, ela derruba as cinco pedras da mão. Mas, no minimo, tratar com educação e paciência, porque eles estão aqui de graça, não é? ver se está tudo em ordem, ver se foi bem atendido... então, acho que essa preocupação tem que ser, assim, no geral, principalmente para quem está ali, atendendo o doador. Às vezes, você não está a fim de ficar sorrindo para o doador, mas tratar com educação e, se a pessoa dá abertura, conversar, brincar, ver quando a pessoa também não gosta de brincar, mantém ali, sempre à distância. Acho que ele tem que ser uma pessoa respeitada, com direitos e com os deveres. $E$, tratar do doador, sair com o doador, 
levar o doador até o lanche, agradecer ele e pedir que ele volte, entendeu? fazer uma nova captação, entendeu? fazer com que o cara volte e traga um amigo. Tem que tentar tratar eles o melhor que puder, para eles voltar sempre, porque não é fácil achar doador de sangue. O mais importante: acolher muito bem; toda vez que você convoca, você estar presente para acolher "que bom! você veio", na hora do doador somos todos seres humanos.

Falo para eles isso aí: vamos ver como é que está... não fica conversando uma coisa que não pode conversar perto dos doador... eu procuro explicar para eles antes, porque... não fala isso, não olha, entendeu? não se vê, isso; então... cada um na sua posição, tentando ajudar um ao outro. (M)

Eu não posso cobrar também... eu sou um auxiliar. A gente não fala porque é colega de trabalho, então... tem que ver tudo isso! (M)

As vezes a gente vem meio nervoso, quer descontar no doador, certo? tem o dia que até pode derrubar pasta de dente na camisa e ficar meio bravo; traz as coisas da casa aqui para dentro do hemocentro... inclusive eu até falei para as pessoas que trabalha com nós ali que, trazer problema de fora para dentro, aqui, vai tratar mal o doador, o doador não vai voltar. (M)

Não pode ser extremamente profissional a ponto de não deixar o humano aparecer, não pode. Tem que ter emoção, tem que ter... eu diria para você que tem que ter amor no que você faz. (U)

$\dot{E}$... informar eles do que vai ser feito, que vai fazer um cadastro, depois vai fazer um teste no dedo, explicar, mais ou menos, o que vai acontecer dentro da doação, explico o que eu estou fazendo com o doador, entendeu? Coleto, explico o que eu estou coletando, o que é isso que eu estou coletando, o que é aquilo às vezes, o doador, é a primeira vez que está doando... "agora eu vou picar... agora eu vou limpar seu dedo" ou "agora vou limpar seu braço", passar as orientações bem devagar e bem detalhadas depois da doação... porque às vezes a pessoa... "ai, nem ouvi direito, ah, não falou nada". Dispenso o doador olhando para a cara do doador, porque eu acho que isso é importante, falar "olha, o senhor não pode beber, fumar, fazer esforço fisico nenhum, tá?". A gente sempre está pedindo para voltar: gostou da primeira vez, pode voltar dali três meses, dali quatro meses... (M)

Ali quando só o doador, que eles, de costas, começa conversar o grupinho, deixa o doador para trás: o doador fica constrangido: "nossa, nem deu atenção para mim?" já falei um monte de vezes para a chefia, lá... sabe, se não der atenção para eles, eles ficam constrangidos, mesmo. (M)

$E$ ele tem que sentir que existe humanidade, não pode sentir frieza na instituição, embora, ela seja séria no trabalho. Já teve caso de algum doador reclamar de algum funcionário... eu nunca vi reclamações assim, constantes, não é? eventualmente, raramente... teve épocas que tinha mais. (U)

Se nós agendasse 50 pessoas por dia, não teria esse amontoado de pessoas brigando, às vezes tá discutindo, brigando ai, porque é um horário de trabalho, o outro quer horário de outra coisa... levar o filho na escola, se a gente poderia agrupar ai e agendar todo o mundo. (M) 